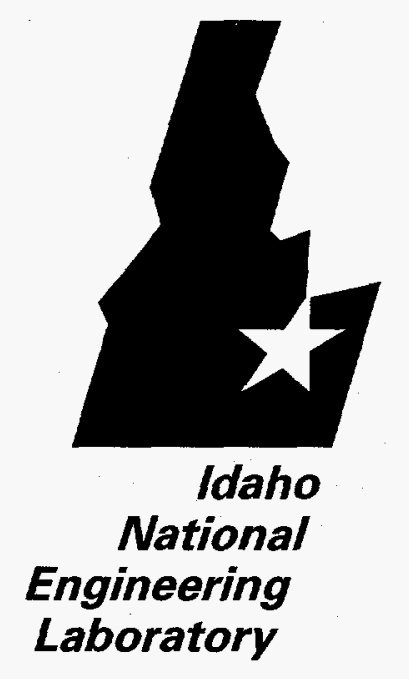

April 1998

\title{
ICPP Tank Farm Planning Through 2012
}

\author{
RECEIVED \\ JUL $O$ Y 1998 \\ OSTI
}

W. B. Palmer

C. B. Millet

M. D. Staiger

F. S. Ward

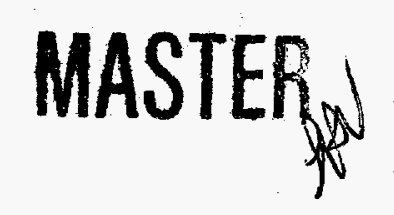

DISTRIBUTION OF THIS DOCUMENT IS UNEMATPC

LOCKHEED MA RTINT 


\section{DISCLAIMER}

This report was prepared as an account of work sponsored by an agency of the United States Government. Neither the United States Government nor any agency thereof, nor any of their employees, makes any warranty, express or implied, or assumes any legal liability or responsibility for the accuracy, completeness, or usefulness of any information, apparatus, product, or process disclosed, or represents that its use would not infringe privately owned rights. Reference herein to any specific commercial product, process, or service by trade name, trademark, manufacturer, or otherwise does not necessarily constitute or imply its endorsement, recommendation, or favoring by the United States Government or any agency thereof. The views and opinions of authors expressed herein do not necessarily state or reflect those of the United States Government or any agency thereof. 


\section{DISCLAIMER}

Portions of this document may be illegible in electronic image products. Images are produced from the best available original document. 
INEEL/EXT-98-00339

\section{ICPP Tank Farm Planning Through 2012}

Published April 1, 1998

Idaho National Engineering and Environmental Laboratory Department

High Level Waste Program

Lockheed Martin Idaho Technologies Company

Idaho Falls, Idaho 83415

Prepared for the

U.S. Department of Energy

Under DOE Idaho Operations Office

Contract DE-AC07-94ID13223 


\section{SUMMARY}

Historically, liquid high-level waste $(\mathrm{HLW})$ generated at the Idaho Chemical Processing Plant has been stored in the Tank Farm after which it is calcined with the calcine being stored in stainless steel bins. Following the curtailment of spent nuclear fuel reprocessing in 1992, the HLW treatment methods were re-evaluated to establish a path forward for producing a final waste form from the liquid sodium bearing wastes (SBW) and the HLW calcine. An Environmental Impact Statement and Record of Decision will be issued in 1999 to specify the HLW treatment method. Until that time, the baseline treatment method is assumed to be calcination, which will continue through 2012. The calcination process has been operated since 1963, but increasingly strict regulatory requirements will probably require significant upgrades to the facility for continued operation. A draft waste treatment plan was issued in September 1997 that was based on information developed for the 2006 Plan and a presentation to EM-1 during a visit to the Idaho National Engineering and Environmental Laboratory in September 1997. Based on the assumptions in that plan, all of the SBW (existing and future) could not be calcined by the end of 2012 as required by the Idaho Settlement Agreement. Since September, projections for significant improvements in waste generation, waste blending and evaporation, and calcination were incorporated into the Tank Farm modeling. This optimized modeling shows that all of the SBW can be calcined by the end of 2012 as required by the Idaho Settlement Agreement.

This Tank Farm plan discusses the use of each of the eleven HLW tanks and shows that two tanks can be emptied, allowing them to be Resource Conservation and Recovery Act closed by 2006. In addition, it describes the construction of each tank and vault, gives the chemical concentrations of the contents of each tank, based on historical input and some sampling, and discusses the regulatory drivers important to Tank Farm operation. It also discusses new waste generation, the computer model used for the Tank Farm planning, the operating schedule for each tank, and the schedule for when each tank will be empty and closed. 


\section{CONTENTS}

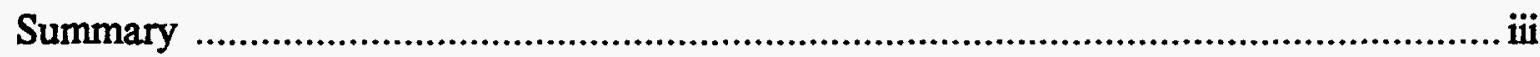

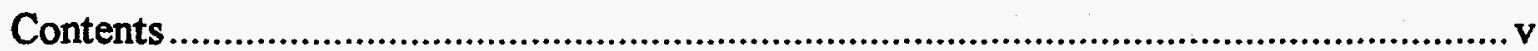

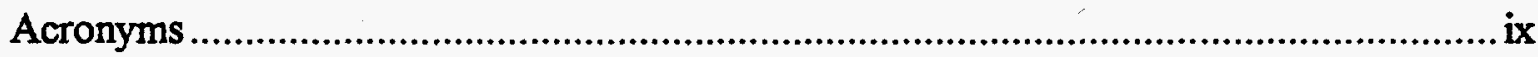

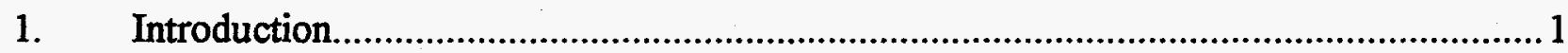

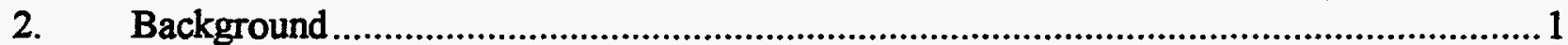

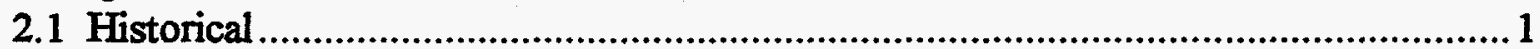

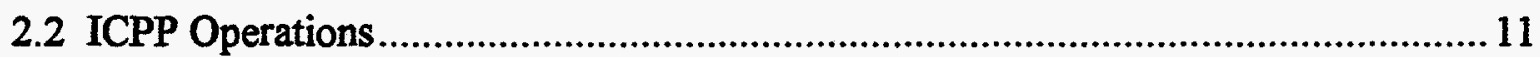

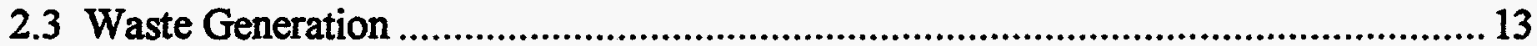

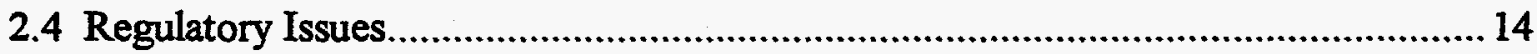

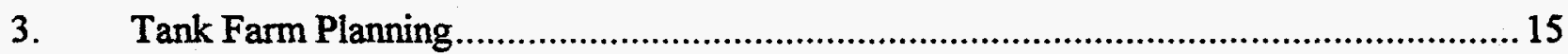

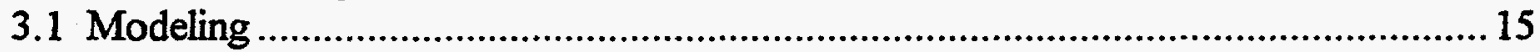

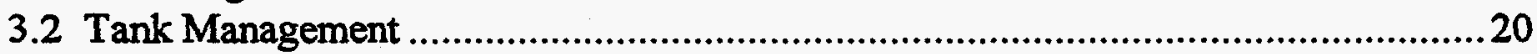

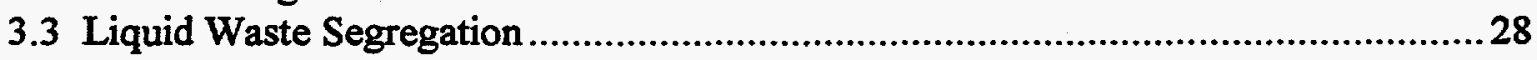

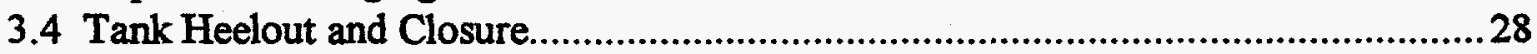

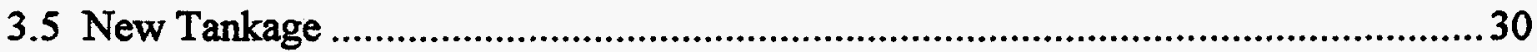

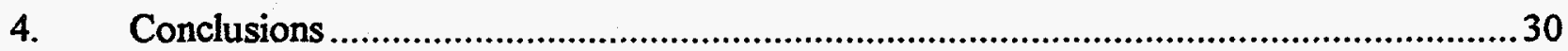

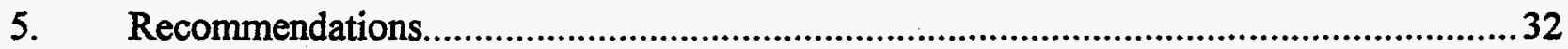

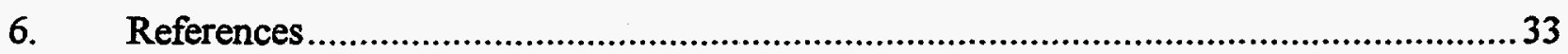

Appendix A - Tank Farm Waste Concentrations

Appendix B - Detailed Waste Tank Operations for 2006 Plan Case

Appendix C - Detailed Waste Tank Operations for the December 1997 Case

Appendix D - Historical Operations of the Tank Farm

Appendix E - Waste Segregation Plan 


\section{FIGURES}

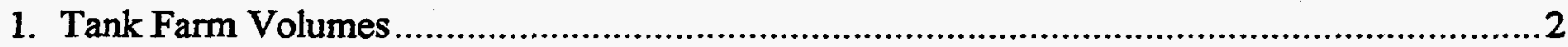

2. Typical First-Cycle Liquid Waste Tank at ICPP .......................................................... 3

3. Octagonal Poured-in-Place Vault for WM-180 .................................................... 4

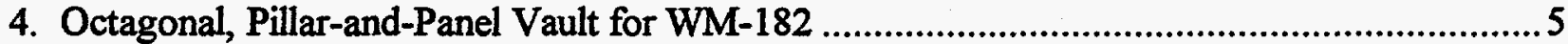

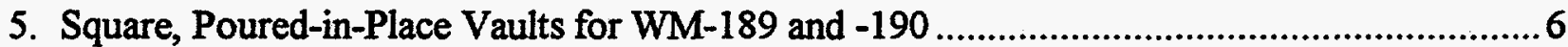

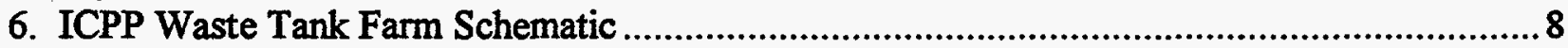

7. Projected NWCF Operations Schedule ................................................................... 17

8. Waste Inventory for ICPP Tank Farm Liquid for the 2006 Plan Case..............................21

9. Waste Inventory for ICPP Tank Farm Liquid for December 1997 Case..............................23

10. Tank Farm Heelout and Closure Schedule .............................................................. 31

TABLES

1. Summary of Waste Tank Design Information..............................................................

2. High Level Waste Treatment Milestones FY-1997 to FY-2012 .................................... 10

3. Typical Liquid Waste Chemical Composition........................................................ 12 


\title{
ACRONYMS
}

\author{
API \\ APS \\ CBI \\ CSSF \\ DOE \\ EM \\ EPA \\ FY \\ HLLW \\ HLLWE \\ HLW \\ ICPP \\ ID \\ INEEL \\ LET\&D \\ LMITCO \\ MACT \\ NEPA \\ NON \\ NOx \\ NWCF \\ ORR \\ PEW \\ PEWE \\ RCRA \\ RHIF \\ ROD \\ SBW \\ SNF \\ STP \\ VOG \\ WCF \\ 2006 Plan \\ American Petroleum Institute \\ Atmospheric Protection System \\ Chicago Bridge \& Iron Company \\ Calcined Solids Storage Facility \\ Department of Energy \\ Environmental Management \\ Environmental Protection Agency \\ Fiscal year (October 1 through September 30) \\ High-level liquid waste \\ High-level liquid waste evaporator \\ High-level waste \\ Idaho Chemical Processing Plant \\ Idaho Operations Office \\ Idaho National Engineering and Environmental Laboratory \\ Liquid Effluent Treatment and Disposal \\ Lockheed Martin Idaho Technologies Company \\ Maximum Achievable Control Technology \\ National Environmental Policy Act \\ Notice of Noncompliance \\ Nitrogen Oxides \\ New Waste Calcining Facility \\ Operational Readiness Review \\ Process Equipment Waste \\ Process Equipment Waste Evaporator \\ Resource Conservation and Recovery Act \\ Remote Handled Immobilization Facility \\ Record of Decision \\ Sodium bearing waste \\ Spent Nuclear Fuel \\ Site Treatment Plan \\ Vessel Off gas \\ Waste Calcining Facility \\ The INEEL Environmental Management Accelerating Cleamup: \\ Focus on 2006, Discussion Draft, PLN-177, June 1997
}




\section{ICPP Tank Farm Planning Through 2012}

\section{INTRODUCTION}

Essentially all of the high level waste (HLW) at the Idaho National Engineering and Environmental Laboratory (INEEL) exists at the Idaho Chemical Processing Plant (ICPP). It was produced from 1953 to 1992 during the reprocessing of spent nuclear fuel (SNF) from many different types of reactors. The reprocessing produced radioactive liquid waste that was further processed to a granular solid form by a process called calcination. The waste management plan for the ICPP, for many years, was basically to continue to reprocess SNF and calcine the waste for the foreseeable future. In April 1992, the U. S. Department of Energy (DOE) announced that spent fuel would no longer be reprocessed to recover enriched uranium and called for a shutdown of the reprocessing facilities at the ICPP. That decision significantly changed the planned waste management activities at the ICPP. Instead of planning for a future of continued reprocessing and the associated waste processing, the planning now must focus on accelerated treatment of the existing waste so the contaminated facilities can be shut down in an orderly fashion that continues to meets all regulatory requirements. The purpose of this report is to present the baseline plan for operation of the ICPP waste Tank Farm and a potential alternative for achieving the requirements laid out in the Idaho Settlement Agreement.

Because of the complexity of the overall waste management processes at the ICPP, other systems in addition to the Tank Farm are discussed to understand the factors affecting the Tank Farm. These other systems include the New Waste Calcining Facility (NWCF), Liquid Effluent Treatment and Disposal (LET\&D), and the High-Level Liquid Waste Evaporator (HLLWE). Since the Tank Farm is used to store hazardous wastes, its operation is subject to Resource Conservation and Recovery Act (RCRA) rules. This further increases the complexity of operation and closure.

\section{BACKGROUND}

\subsection{Historical}

Irradiated nuclear fuel has been stored and reprocessed at the INEEL since 1953 using facilities located at the ICPP. The reprocessing recovered uranium- 235 and krypton- 85 for the DOE and its predecessor organizations. The resulting radioactive waste exists in both liquid and solid (calcine) forms.

Two types of liquid waste have been stored; they are high level liquid waste (HLLW, sometimes termed non-sodium bearing waste) and sodium bearing waste (SBW). The HLLW was generated as a direct result of reprocessing SNF and the SBW was generated from incidental activities, such as decontamination, associated with operation of the ICPP. Although the liquid SBW is stored and treated in the same manner as the HLLW, it is actually a mixed transuranic waste. In April 1992, DOE announced that spent nuclear fuel would no longer be reprocessed and called 
for a shutdown of the reprocessing facilities at the ICPP. Since that time, no more HLLW has been (or will be) generated. The production of SBW is dependent on how much and what type of work is done at the ICPP in the future, especially in the area of decontamination and decommissioning. At the end of Fiscal Year 1997 (FY-97) there were approximately 147,000 gallons of HLLW (or non-sodium bearing waste) and 1,400,000 gallons of SBW stored in the ICPP Tank Farm (Figure 1). Tank WM-188 holds the remaining HLLW inventory.

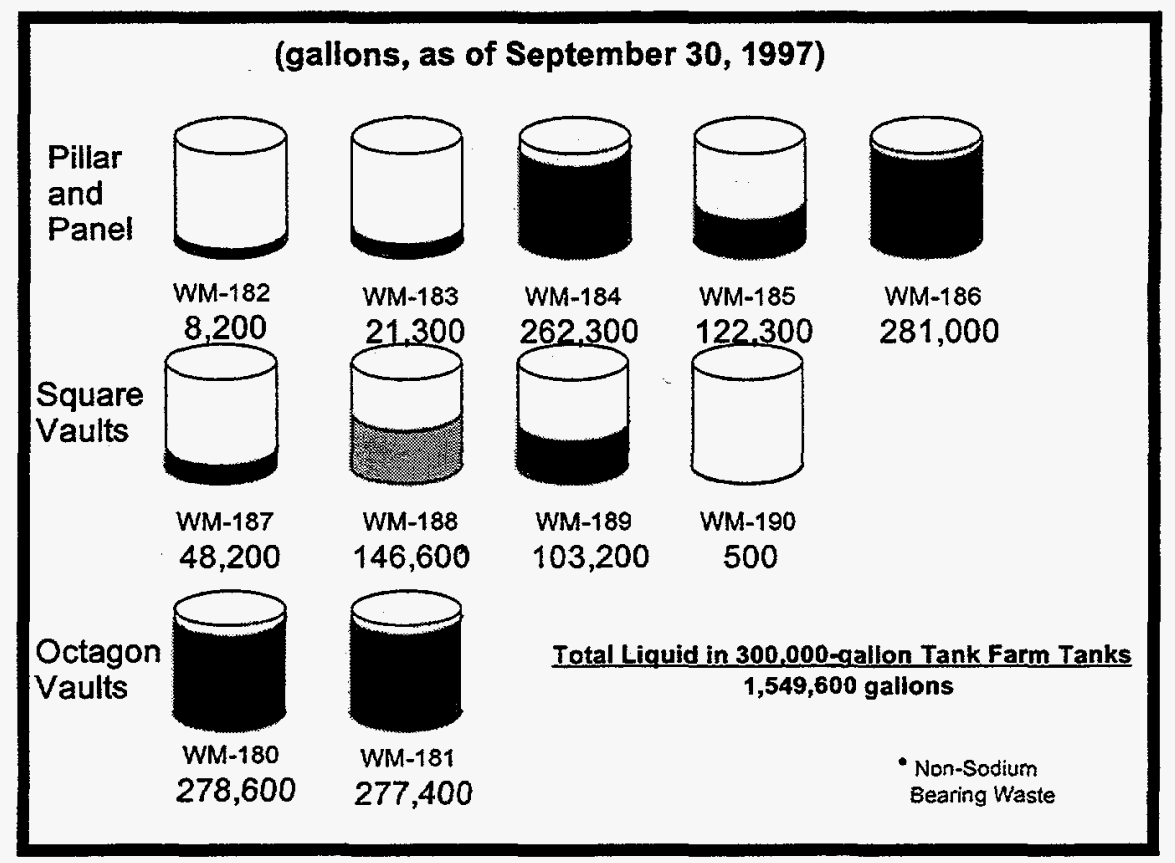

Figure 1. Tank Farm Volumes.

All of the liquid waste is stored in the ICPP Tank Farm, which consists of eleven 300,000-gallon stainless steel tanks housed in underground concrete vaults (Figure 2). All of the tanks are similar in design, but the vault designs are significantly different. The ICPP began operations in the early 1950s with two liquid waste tanks (WM-180 and WM-181) which were constructed from 1950 to 1953. These two tanks have vaults that are monolithic, reinforced concrete in an octagonal shape (Figure 3). As the scope of the ICPP operations increased, additional tanks were put into service. Tanks WM-182 through WM-186 were constructed from 1953 to 1957. These five tanks are also contained in octagonal vaults, but these are of pre-fabricated pillar and panel construction (Figure 4). The four newest large liquid waste tanks, WM-187 through WM-190, were constructed from 1959 to 1965 and are housed in a four-sectioned, monolithic, reinforced concrete vault (Figure 5). All of these tanks were designed and built to the standards at the time of construction and have served their designed function. The design of the vaults is important because the pillar and panel construction is not considered as robust as the monolithic construction and the unlined concrete in all of the vaults does not meet RCRA secondary containment requirements. Although liquid waste leaks have occasionally occurred in associated valves and piping, liquid waste leaks from waste tanks have never occurred. Even though some of the tanks are over 40 years old, based on corrosion monitoring results, they are sound and are expected to continue their reliable service for the additional 10-20 years required of them. Table 1 provides construction details and Figure 6 shows the Tank Farm layout. 


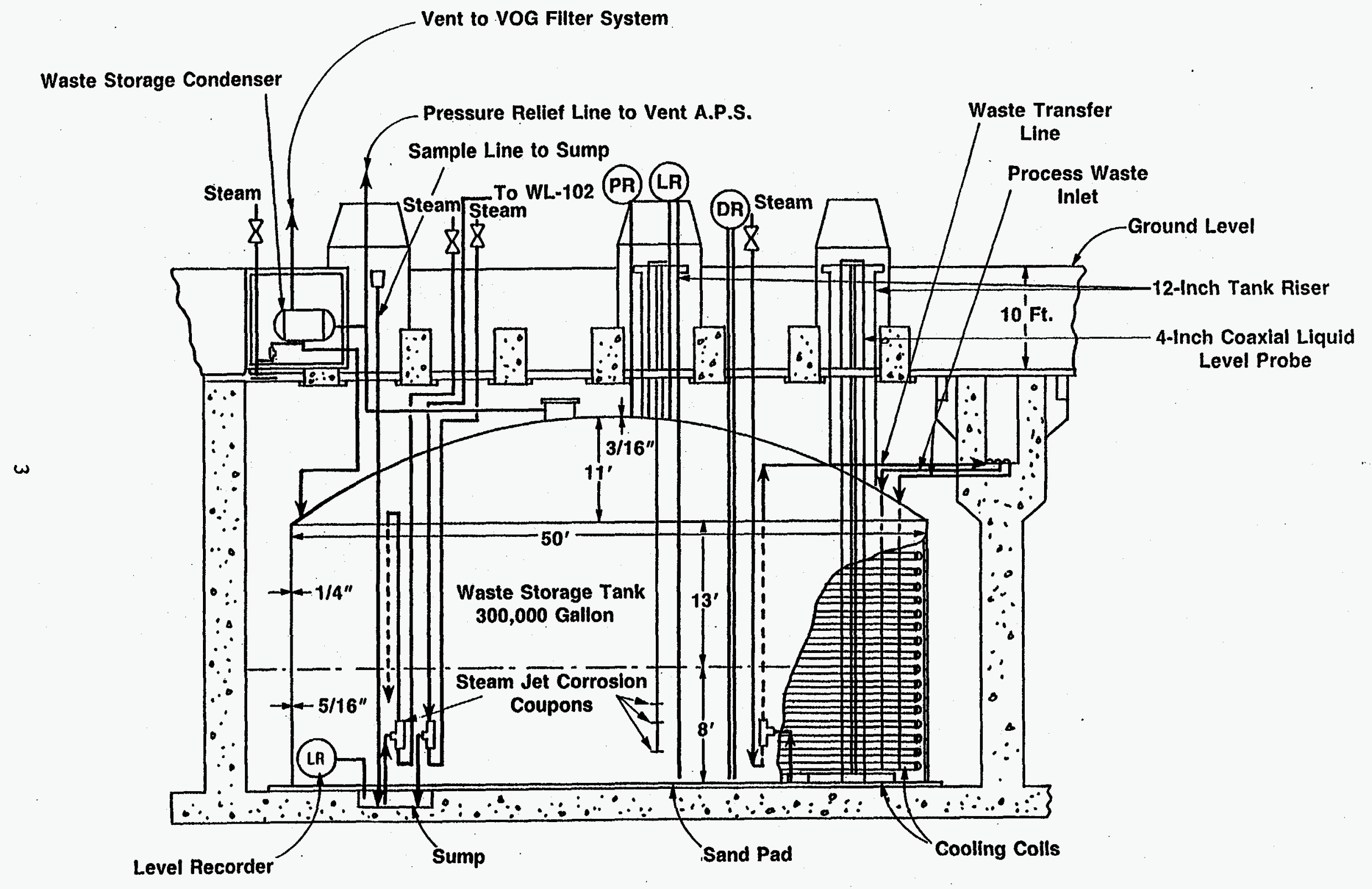

Typical First-Cycle Liquid Waste Tank at ICPP 


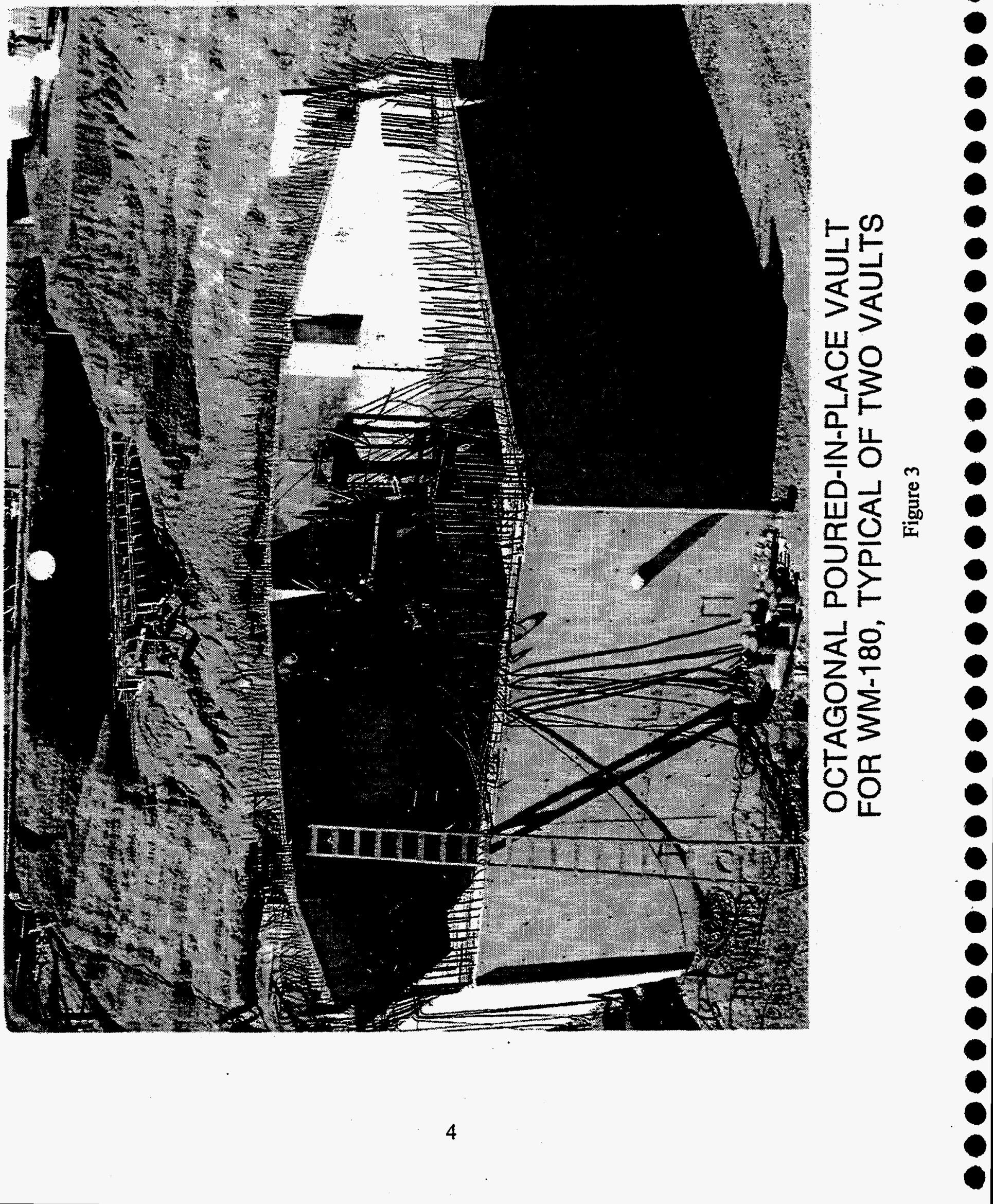




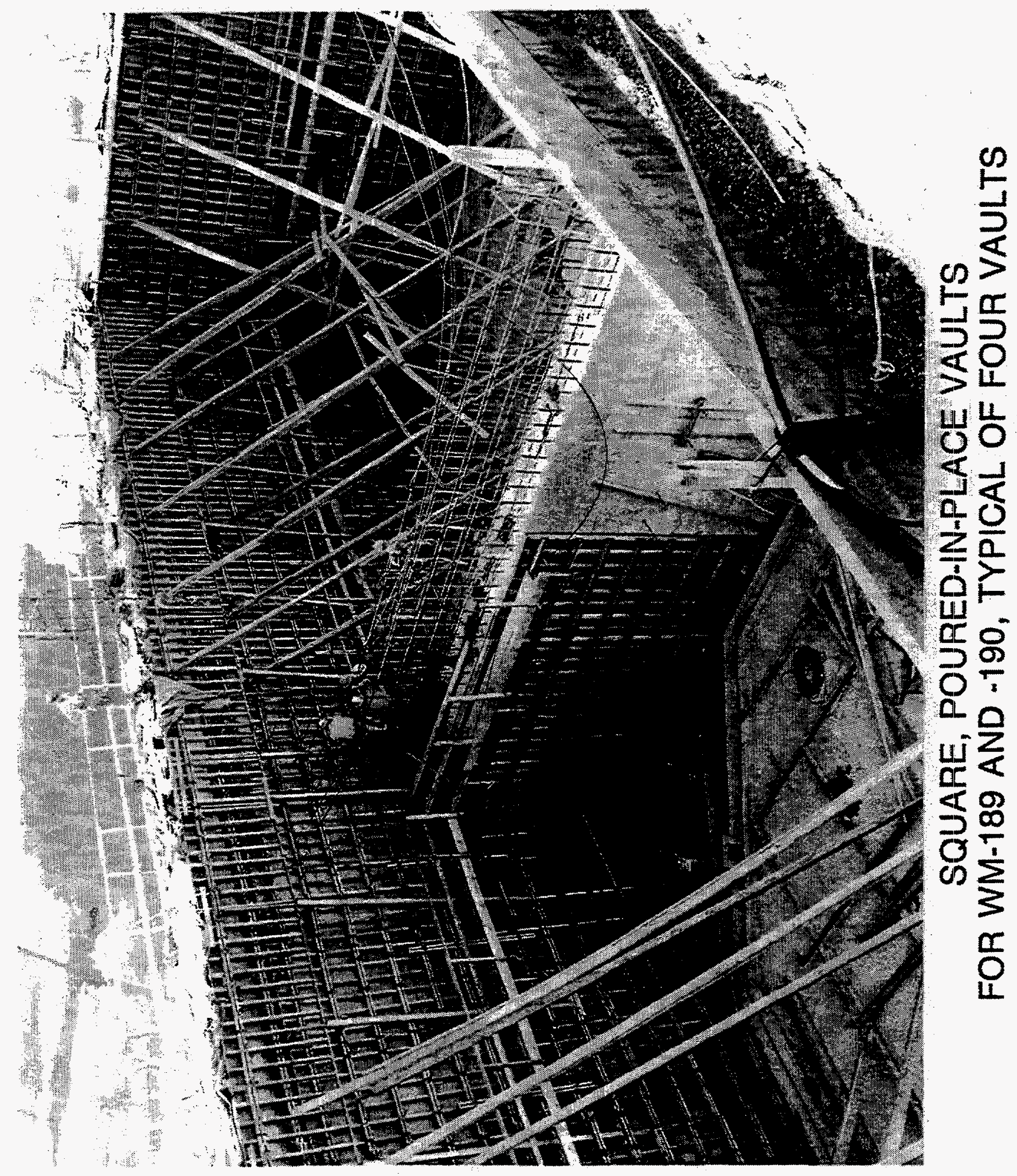




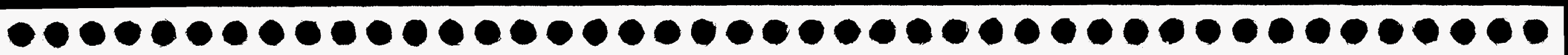

Table 1. Summary of Waste Tank Design Information.

\begin{tabular}{|c|c|c|c|c|c|c|c|c|c|c|c|}
\hline & WM-180 & WM-181 & WM-182 & WM-183 & WM-184 & WM-185 & WM-186 & WM-187 & WM-188 & WM-189 & WM-190 \\
\hline Design Organization & Foster-Wheeler & Foster-Wheeler & Blaw-Knox & Blaw-Knox & Blaw-Knox & Fluor Corp. & Fluor Corp. & Fluor Corp. & Fluor Corp. & Fluor Corp. & Fluor Corp. \\
\hline Tank Subcontractor & CBI & CBI & CBI & CBI & CBI & CBI & CBI & $\begin{array}{l}\text { Hammond } \\
\text { Iron }\end{array}$ & $\begin{array}{l}\text { Hammond } \\
\text { Iron }\end{array}$ & $\begin{array}{l}\text { Industrial } \\
\text { Contractors }\end{array}$ & $\begin{array}{l}\text { Industrial } \\
\text { Contractors }\end{array}$ \\
\hline Years Constructed & $1951-1952$ & $1951-1952$ & $1954-155$ & $1954-1955$ & 1954-1955 & 1957 & $1955-1957$ & $1958-1959$ & $1958-1959$ & 1964 & 1964 \\
\hline Initial Service Date & 1954 & 1953 & 1955 & 1958 & 1958 & 1959 & 1962 & 1959 & 1963 & 1966 & Spare \\
\hline Design Codes & Unknown & Unknown & API-12C & API-12C & API-12C & API-12C & API-12C & API-12C & API-12C & API-650 & API-650 \\
\hline Cooling Coils & Yes & No & Yes & Yes & No & Yes & No & Yes & Yes & Yes & Yes \\
\hline Tank Diameter (feet) & 50 & 50 & 50 & 50 & 50 & 50 & 50 & 50 & 50 & 50 & 50 \\
\hline $\begin{array}{l}\text { Tank Height To } \\
\text { Springline (feet) }\end{array}$ & 23 & 23 & 21 & 21 & 21 & 21 & 21 & 21 & 21 & 21 & 21 \\
\hline Tank Capacity (gal) & 318,000 & $.318,000$ & 300,000 & 300,000 & 300,000 & 300,000 & 300,000 & 300,000 & 300,000 & 300,000 & 300,000 \\
\hline $\begin{array}{l}\text { Lower Tank } \\
\text { Thickness (inches) }\end{array}$ & 0.3125 & 0.3125 & 0.3125 & 0.3125 & 0.3125 & 0.3125 & 0.3125 & 0.3125 & 0.3125 & 0.3125 & 0.3125 \\
\hline $\begin{array}{l}\text { Upper Tank } \\
\text { Thickness (inches) }\end{array}$ & 0.25 & 0.25 & 0.25 & 0.25 & 0.25 & 0.25 & 0.25 & 0.25 & 0.25 & 0.25 & 0.25 \\
\hline $\begin{array}{l}\text { Corrosion Allowance } \\
\text { (mils) }\end{array}$ & Unknown & Unknown & 125 & 125 & 125 & 125 & 125 & 125 & 125 & 125 & 125 \\
\hline $\begin{array}{l}\text { Type of Stainless } \\
\text { Steel }\end{array}$ & 347 & 347 & $304 \mathrm{~L}$ & $304 \mathrm{~L}$ & $304 \mathrm{~L}$ & $304 \mathrm{~L}$ & 304L & $304 \mathrm{~L}$ & $304 \mathrm{~L}$ & $304 \mathrm{~L}$ & 304L \\
\hline $\begin{array}{l}\text { Design Liquid } \\
\text { Specific Gravity }\end{array}$ & 1.3 & 1.3 & 1.4 & 1.4 & 1.4 & 1.4 & 1.4 & 1.4 & 1.4 & 1.4 & 1.4 \\
\hline
\end{tabular}




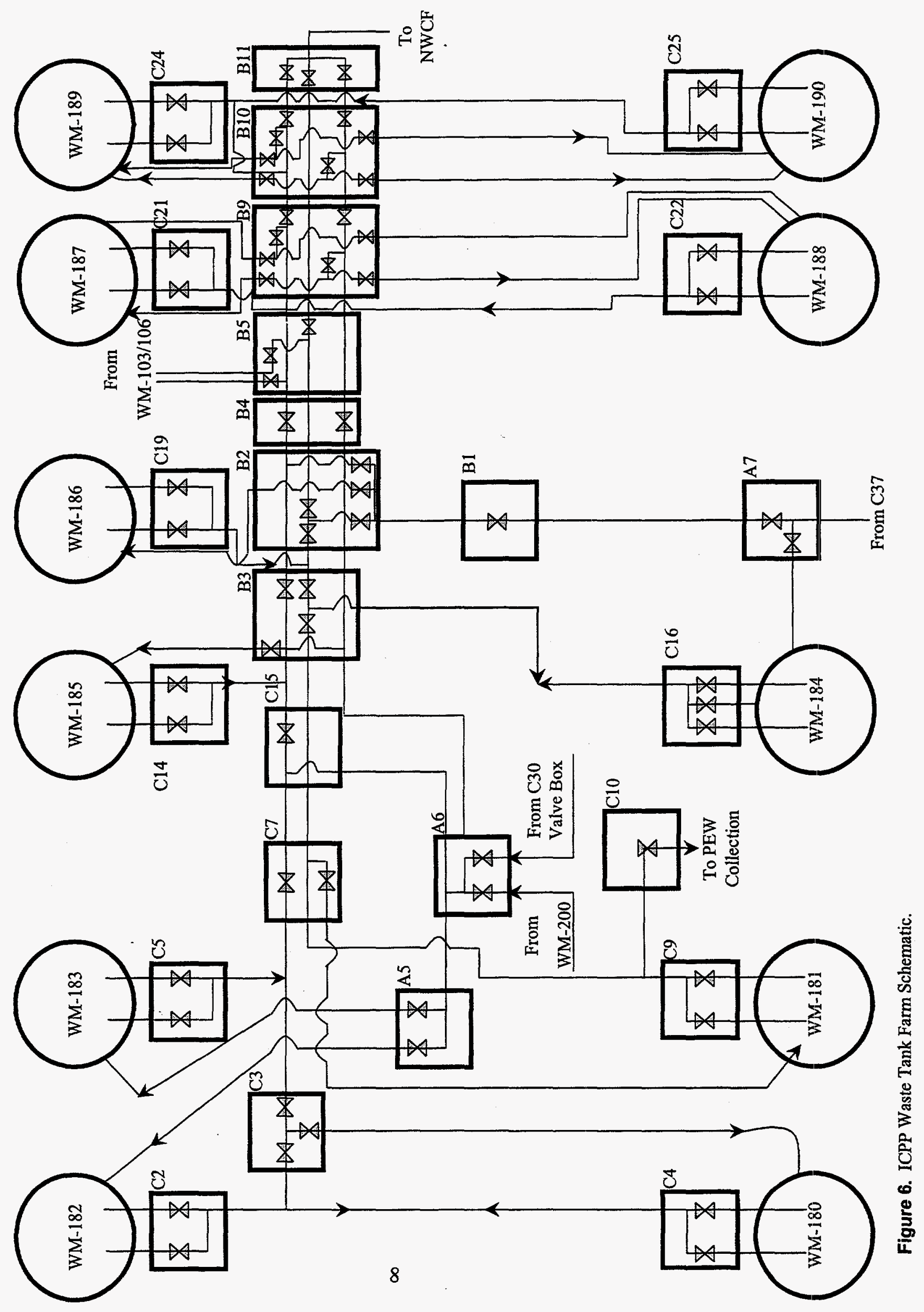


The two major waste operations currently employed for ICPP liquid wastes are evaporation and calcination. Evaporation is performed by a thermosyphon evaporator and is used to remove unneeded water from the waste for more efficient storage and improved calcinability. The calcination process has been used since 1963 to solidify HLLW. Calcination evaporates the remaining water from the waste and converts the remaining materials to granular solids. This operation not only makes waste storage more efficient due to the volume decrease (historically about a 7 to 1 reduction), but also makes the waste much less corrosive, which is very important for long-term storage. The calcine solids from this process are stored in bin sets. There are approximately $3910 \mathrm{~m}^{3}$ of calcine stored at the ICPP. If all existing and future liquid wastes are solidified, approximately $2000 \mathrm{~m}^{3}$ more calcine will be produced. Careful development, testing, and process control are used to assure the calcine sent to the bin sets remains free flowing to assure retrievability. Sampling of calcine in Bin Set 2 during 1978 showed that the calcine had indeed remained free flowing after approximately ten years of storage. Based on these results, calcine is expected to be readily retrievable to allow further treatment.

The major legal drivers associated with management of ICPP HLLW are shown in Table 2. Although all are important, those of greatest concern are:

- Calcine all remaining non-sodium bearing high level waste by June 30, 1998

- Commence calcination of SBW by June 1,2001

- Cease use of the waste tanks contained in pillar and panel vaults by March 31, 2009

- $\quad$ Complete calcination of SBW by December 31, 2012

These four drivers came about as a result of the tank vaults' lack of adequate secondary containment mentioned above. Since the pillar and panel tanks are of the greatest concern because of the additional potential seismic problem, the date for their retirement comes earlier than for the other tanks. 
Table 2. High Level Waste Treatment Milestones FY-1997 to FY-2012.

\begin{tabular}{||l|l|l||}
\hline DATE & REQUIREMENT & SOURCE $^{\text {a }}$ \\
\hline 31 OCT 96 & Commence operation of the HLLW evaporator & Set. Agree. E3 \\
\hline 1 JUL 97 & $\begin{array}{l}\text { Solicit proposals for feasibility studies for treatment of calcined } \\
\text { waste }\end{array}$ & Set. Agree. E6 \\
\hline 31 DEC 97 & $\begin{array}{l}\text { Operate the HLLW evaporator to reduce tank farm liquid waste } \\
\text { volume by no fewer than 330,000 gallons } \\
\text { Calcine all remaining non-sodium bearing liquid high-level } \\
\text { waste }\end{array}$ & Set. Agree. E3 \\
\hline 31 DEC 99 & $\begin{array}{l}\text { Commence negotiating a plan and schedule for calcined waste } \\
\text { treatment }\end{array}$ & Set. Agree. E6 \\
\hline 1 JUN 01 & $\begin{array}{l}\text { Commence calcination of sodium-bearing liquid high-level } \\
\text { wastes }\end{array}$ & Set. Agree. E5 \\
\hline 31 MAR 2009 & $\begin{array}{l}\text { Cease use of waste tanks contained in pillar and panel vaults } \\
\text { NON Consent } \\
\text { Order }\end{array}$ \\
\hline 31 DEC 2009 & Issue record of decision for calcined waste treatment & Set. Agree. E6 \\
\hline 1 DEC 2012 & $\begin{array}{l}\text { Submit application for a RCRA Part B permit for calcined waste } \\
\text { treatment }\end{array}$ & Set. Agree. E6 \\
\hline
\end{tabular}

a. The $\mathrm{E}$ followed by a number in this column refers to the specific Settlement Agreement section and paragraph.

Over two dozen studies have been completed since 1993 to determine the preferred method for treating the ICPP HLW inventory. References 1 and 2 are examples of the types of studies performed. These studies concluded that to meet consent order requirements and minimize lifecycle costs of the waste treatment process, two major actions should occur. The first action would be to continue calciner operation. The second action would be to construct and operate, as soon as possible, a new treatment facility to immobilize current as well as future wastes. The new process is termed the Remote Handled Immobilization Facility (RHIF). This process would treat both liquid and calcine. It would consist of process steps to retrieve and dissolve calcine, separate liquid from undissolved solids, separate radionuclides, vitrify and interim store the high activity waste fraction, and grout and interim store or dispose of the low activity fraction.

The current baseline plan for treating the high-level waste, is presented in The INEEL Environmental Management Accelerating Cleanup: Focus on 2006, Discussion Draft (this document was originally known as the Ten-Year Plan) (Reference 3). The plan calls for continuing the calcination process through 2012 to empty the Tank Farm. To reduce treatment costs, newly generated liquid wastes that are sufficiently low in radioactivity will be segregated and directly grouted without additional treatment. Higher activity liquids will continue to be 
calcined. Even after calcination is completed, liquid waste will still be generated from decontamination, decommissioning, and off-gas treatment activities.

The plan calls for collecting the newly generated liquid waste in new RCRA-compliant tanks from 2012 to 2020 and treating the newly generated liquid waste and existing calcine in the RHIF that operates from 2020 to 2035. As during the calcination treatment phase, newly generated liquid wastes that are sufficiently low in radioactivity will be segregated and directly grouted. With this schedule, calcine treatment would be complete in 2035 so that the high-level waste would be ready to be shipped to a geologic repository. The HLW canisters would ultimately be disposed of in a federal geologic repository such as the one being considered at Yucca Mountain. The low-activity grout would be disposed of in the emptied Tank Farm tanks and calcine storage bins. This baseline plan may be modified by the National Environmental Policy Act (NEPA) activity, which is in progress.

\subsection{ICPP Operations}

An extensive liquid waste management system is in place at the ICPP. The major processing and storage units consist of the Tank Farm, the Process Equipment Waste Evaporator (PEWE), the LET\&D Facility, the NWCF, the HLLWE, and the Calcined Solids Storage Facilities (CSSF).

Radioactive and hazardous wastes generated from present ICPP operations are generally concentrated in the PEWE prior to storage in the Tank Farm or occasionally sent directly to the Tank Farm. Acid in the PEWE overheads is separated for recycle by the LET\&D fractionators. The HLLWE is used to further concentrate wastes stored in the Tank Farm and to prepare them for calcination in NWCF. In the NWCF, the liquid wastes are sprayed into a hot $\left(500^{\circ} \mathrm{C}\right)^{\mathrm{a}}$ fluidized bed. The water and volatile chemicals quickly evaporate and the remaining chemicals are converted to a solid granular form, which is then stored in the CSSF.

Table 3 shows typical chemical compositions for the HLLW that has been stored in the Tank Farm. The zirconium and aluminum reprocessing wastes were readily calcined due to their high concentration of dissolved metal ions. SBW, which is nearly 100 times higher in sodium and potassium content, cannot be calcined directly because the sodium and potassium form compounds that melt at calcination and bin storage temperatures. Melting of the calcine would cause the calcine to agglomerate in the fluidized bed or CSSF; this would shut down the calcination process or prevent retrieval from the CSSF and further processing to a final waste form. In the past, the NWCF has processed SBW by blending it with fuel reprocessing wastes (approximately three volumes of reprocessing waste to each volume of SBW). The blending diluted the sodium and potassium sufficiently for successful calciner operation. Since the ICPP is no longer reprocessing spent fuel, no more reprocessing waste will be generated. Tank WM188 contains the last of the reprocessing waste and once it is emptied, no more blending can occur. Because of this, calcination of the remaining Tank Farm wastes will proceed more slowly than in the past because the SBW will have to be blended with non-radioactive materials, such as

\footnotetext{
This temperature may be increased to $600^{\circ} \mathrm{C}$ in the future to increase the processing rate of SBW.
} 
Table 3. Typical Liquid Waste Chemical Composition.

\begin{tabular}{|c|c|c|c|c|c|}
\hline Major Species & Units & Zirconium & Fluorinel & Sodium Bearing & Aluminum \\
\hline Acid $\left(\dot{\mathrm{H}}^{+}\right)$ & Molar & 1.4 & 1.5 & 1.28 & 0.81 \\
\hline Aluminum (Al) & Molar & 0.68 & 0.43 & 0.57 & 1.5 \\
\hline Zirconium (Zr) & Molar & 0.41 & 0.31 & & \\
\hline Boron (B) & Molar & 0.19 & 0.15 & 0.017 & \\
\hline Cadmium (Cd) & Molar & & 0.05 & 0.001 & \\
\hline Sodium $(\mathrm{Na})$ & Molar & 0.017 & 0.02 & 1.50 & 0.06 \\
\hline Potassium (K) & Molar & 0.003 & & 0.17 & \\
\hline Chromium (Cr) & Molar & 0.015 & 0.015 & & \\
\hline Iron $(\mathrm{Fe})$ & Molar & 0.007 & 0.005 & 0.002 & 0.01 \\
\hline $\operatorname{Tin}(\mathrm{Sn})$ & Molar & 0.005 & 0.004 & & 5.40 \\
\hline Mercury (Hg) & Molar & & & 0.0013 & 0.02 \\
\hline Fluoride $(\mathrm{F})$ & Molar & 3.20 & 2.10 & 0.04 & \\
\hline Chloride (Cl) & $\mathrm{mg} / \mathrm{L}$ & & 50 & 1000 & \\
\hline Nitrate $\left(\mathrm{NO}_{3}\right)$ & Molar & 2.30 & 1.90 & 4.50 & 5.40 \\
\hline Sulfate $\left(\mathrm{SO}_{4}\right)$ & Molar & & 0.035 & 0.043 & \\
\hline Uranium $(\mathrm{U})$ & $\mathrm{mg} / \mathrm{L}$ & 1.30 & 6.5 & 66.4 & \\
\hline Undissdolved Solids & $\mathrm{g} / \mathrm{L}$ & 2.0 & 2.0 & 2.4 & \\
\hline Specific Gravity & $\mathrm{g} / \mathrm{m} \bar{L}$ & 1.20 & 1.15 & 1.25 & 1.28 \\
\hline
\end{tabular}


aluminum nitrate, for successful calcination. The current estimated chemical and radionuclide compositions of the Tank Farm wastes, based on historical processing and some sample analyses, are provided in Appendix A.

The liquid waste stored in the Tank Farm has been maintained in the acid condition and, because of this, solids precipitation has not occurred and the waste is a clear (although colored) liquid. This liquid has been routinely transferred from tanks to the calcining facility with no significant problems; this same success in transferring liquid wastes is expected for processing the remaining Tank Farm wastes. Since the wastes are stable and contain very few precipitated solids, sampling and analysis are relatively easy when compared to sampling mixtures of solids, sludge, and liquid which commonly exist in waste tanks at the other DOE sites; however, the sampling and analyses are still time consuming and expensive. All of the liquid wastes have been sampled and the general chemical and radionuclide compositions have been determined. Obtaining the detailed chemical characterizations required by RCRA is in progress and will take several years to complete.

Ultimately, the Tank Farm wastes and calcine must be converted to forms suitable for permanent disposal. The process to treat the waste has yet to be selected. Alternatives under consideration include: continued calcination with long-term bin storage of the calcine (No Action Alternative); immobilization of the calcine into either a glass, glass-ceramic, or cementitious form (Non Separations Alternatives); or dissolution of the calcine and subsequent separation of the waste into high- and low-activity waste streams followed by immobilization of the waste streams (Separations Alternatives). An Environmental Impact Statement and Record of Decision will be issued in 1999, which will select the HLW treatment method.

\subsection{Waste Generation}

Historically, the major waste stream stored in the Tank Farm was from spent nuclear fuel reprocessing. When reprocessing was terminated in 1992, a common misconception, based on questions asked during various HLW Program presentations, was that waste production would cease and the Tank Farm could be rapidly emptied. In actuality, fuel reprocessing was only one of several operations at the ICPP that produced waste. Waste continues to be produced by plant operations such as, fuel storage, sample analyses, off-gas cleanup, Tank Farm and other facilities' sumps, the filter leach process, equipment and facility decontamination, RCRA well sampling, and facility deactivation. In addition, the ICPP can receive liquid waste from other areas within the INEEL with DOE-Idaho Operations Office (ID) approval. However, even though liquid continues to be produced, since fuel is not being processed, essentially no additional radionuclides are being introduced into the ICPP liquid waste management system. Therefore, the radionuclide inventory in the liquid and the associated risk are continually decreasing due to radioactive decay and conversion of the radioactive liquids to calcine solids.

The DOE has challenged the HLW Program to significantly reduce liquid waste generation that goes to the Tank Farm. To meet this challenge Lockheed Martin Idaho Technologies Company (LMITCO) produced a waste minimization plan (Reference 4) where they committed to a 35\% reduction in generated waste volume for the next five years. This plan provides the detailed 
assumptions and volumes used for simulation of waste generation in this report. The waste minimization plan was updated in August 1997 (Reference 5).

\subsection{Regulatory Issues}

Due to aging of the tanks and support facilities and more stringent requirements in the areas of secondary containment and seismic stability, a project was initiated in 1989 to replace the ICPP Tank Farm. The Notice of Noncompliance (NON) issued by the Environmental Protection Agency (EPA) on January 28, 1990, supported the DOE decision to construct replacement tanks by contending that the eleven tanks in the ICPP Tank Farm and much of their associated valves and piping were not in compliance with secondary containment requirements. Specifically, the concrete vaults are unlined and if a tank leaked, the acidic waste would attack and could eventually dissolve a hole through the vault wall or floor.

The pillar and panel construction is not considered as structurally robust as the monolithic designs and may not meet current seismic design standards (Figures 3, 4, and 5 show construction of the three vault types) ${ }^{b}$. The NON Consent Order, signed April 3, 1992, outlined a strict compliance schedule for the completion of several tasks that would ultimately result: in the required permanent cessation of use of the five pillar and panel tank vaults containing Tanks WM-182 through WM-186 on or before March 31, 2009. Cease use for the remaining six monolithic vaults containing Tanks WM-180, WM-181, and WM-187 through WM-190 would occur on or before June 30,2015 , among other provisions.

The Idaho Settlement Agreement, signed October 17, 1995 (Reference 6), requires all SBW to be calcined by December 31, 2012. Although there is some thought that this requirement effectively moves the cease-use date for the last six tanks ahead two and one-half years from the June 30, 2015 date, the tanks could potentially be used for some other purpose, such as newly generated liquid waste storage, until 2015. Additional regulatory details are provided in Regulatory Analysis and Proposed Path Forward for the INEL HLW Program (Reference 7). The Site Treatment Plan, Reference 8 , also specifies treatment requirements (such as schedule) for the Tank Farm waste.

The NWCF was proposed during the Site Treatment Plan (STP) negotiations to continue operating under Part A RCRA Interim Status until 2012 as part of the 1992 NON. From

\footnotetext{
$\mathrm{b}$ The waste tank vaults surrounding the eleven Tank Farm tanks consist of three separate designs. The pillar and panel vaults are the vaults enclosing tanks WM-182 to WM-186. These vaults are precast concrete construction. Sixteen columns are distributed around the octagonal vault perimeter. Six-inch thick vertical precast wall panels are clipped to these columns. The monolithic vaults enclose tanks WM-180, WM-181, and WM-187 through WM-190. The vaults enclosing tanks WM-180 and WM-181 are octagonal in plan and were constructed completely of cast-inplace, reinforced concrete. Tanks WM-187- through WM-190 are laid out on a 2 X 2 grid and are enclosed by a single, rectangular, reinforced concrete vault with partition walls separating the tanks. The exterior and partition walls are integral with the mat.
} 
February 1992 through early 1995, Radian Corporation was contracted to determine and develop, if required, off-gas sampling methods, none of which was successful due to the high concentration of nitrogen oxides (NOx) in the off-gas. Sampling was unsuccessful even at 300$500 \mathrm{ppm} \mathrm{NOx}$ in the main stack because the NOx forms $\mathrm{HNO}_{3}$ in the buffer solutions, which destroys the sample and/or equipment. A method acceptable to the regulators to sample NWCF emissions per the RCRA Part B requirements has not been developed to date. In addition, neither the liquid wastes nor the calcine have been fully characterized per RCRA criteria. Resolution of these issues is required in order to obtain a RCRA Part B permit.

One of the major regulatory requirements which has been recently identified is Maximum Achievable Control Technology (MACT). The MACT rule is expected to be promulgated in Calendar Year 1998 (October 1998 is assumed for the purposes of this study) and the regulators will require NWCF to meet MACT. If the NWCF is required to meet the MACT rule, the following are evident:

- The NWCF will most likely be able to continue operation through 1998 to complete processing of the non-SBW as required by the Settlement Agreement.

- While operation after 1998 may be in jeopardy, DOE may be able to negotiate operation through 2001 ( 36 month compliance), or even 2002 if a 12-month extension is granted.

Modifications to the facility required to meet the MACT rule include installation of secondary combustion equipment, NOx removal, emissions monitors, and systems to cool the offgas after the secondary burner. Mercury removal from the feed, scrubbing solution, or offgas would also be required. Process controls for certain parameters are also required. If any of the parameters were exceeded, this system would shut off the feed and require the NWCF to come back to normal before feed could be restarted. These modifications are expected to require significant capital expenditure. Reference 9 provides the details of the requirements and schedule for implementing MACT.

\section{Tank Farm Planning}

\subsection{Modeling}

\section{Tank Farm Plan Model}

The High-Level Waste Program uses simulation modeling to aid in strategic planning and alternatives analysis. The model used in the development of this plan consists of a discrete event simulation employing object oriented design features. The objects which have been modeled consist of the various processing and storage objects used for managing the wastes, reducing the liquid volume through evaporation, and conversion of the liquid waste to a suitable solid waste form. The process objects used in the model for managing the waste in this plan are the NWCF and the HLLWE. The storage objects consist of the eleven tanks in the Tank Farm. 
The variables used in the model consist of processing parameters and throughput rate information gained from numerous laboratory and pilot plant studies, other detailed process and mass balance models, and historical data. Future projections of liquid waste generation have been developed from studies of current waste generation practices and feasible improvements to minimize both sources and volumes requiring storage and processing.

Overall program requirements have been identified at a high level; these requirements were derived primarily from the Settlement Agreement and the Site Treatment Plan. The requirements include those of a legal, regulatory, technical, and fiscal nature. Process and facility modification projects have been identified in order to satisfy some of the requirements. These projects have been evaluated and feasibility studies initiated where appropriate. Schedules have also been developed for implementing the required projects. Schedules and other planning assumptions have been incorporated into the modeling. The major assumptions are presented in the next section. The modeling for liquid waste management within the Tank Farm has generated the graphs for the various cases as discussed in this plan. The functions of receipt, storage, and processing are reflected in tank volumes shown in the figures subsequently presented. The individual case details were also extracted from the modeling results.

\section{Tank Farm Plan Modeling Assumptions}

\section{Schedule:}

The Schedule for NWCF Operations and projects is shown in Figure 7.

- NWCF Campaign cycle 9 months on / 3 months off

A new processing schedule was developed using a more active approach at running the calciner. The schedule is based on a core of 9-month calciner campaigns alternated with 3month turnaround periods for maintenance and modifications.

- MACT compliance will be required with an expected promulgation date of October 1998

A long period, of approximately 7 years, void of processing was required due to the assumption that MACT compliance will be required. The project duration to achieve compliance is constrained by the DOE funding cycle (typically 4 years) and by construction experience estimates (nearly 6 years) for a project of this size and complexity. It was assumed that the NWCF was shut down 3 years ${ }^{c}$ after the expected promulgation date (October 1998) and would not restart until after the MACT Compliance and HighTemperature modifications projects are completed in March of FY-2008. It is further

\footnotetext{
${ }^{c}$ The 3-year assumption may be overly optimistic. A more conservative assumption is that NWCF would be required to shut down for modifications within one year of MACT Rule promulgation. This scenario was not specifically modeled. However, a shutdown within one year of promulgation could cause as much as a 2-year delay in completion of calcination activities and the December 31, 2012 deadline to complete calcination of SBW would likely be missed.
} 


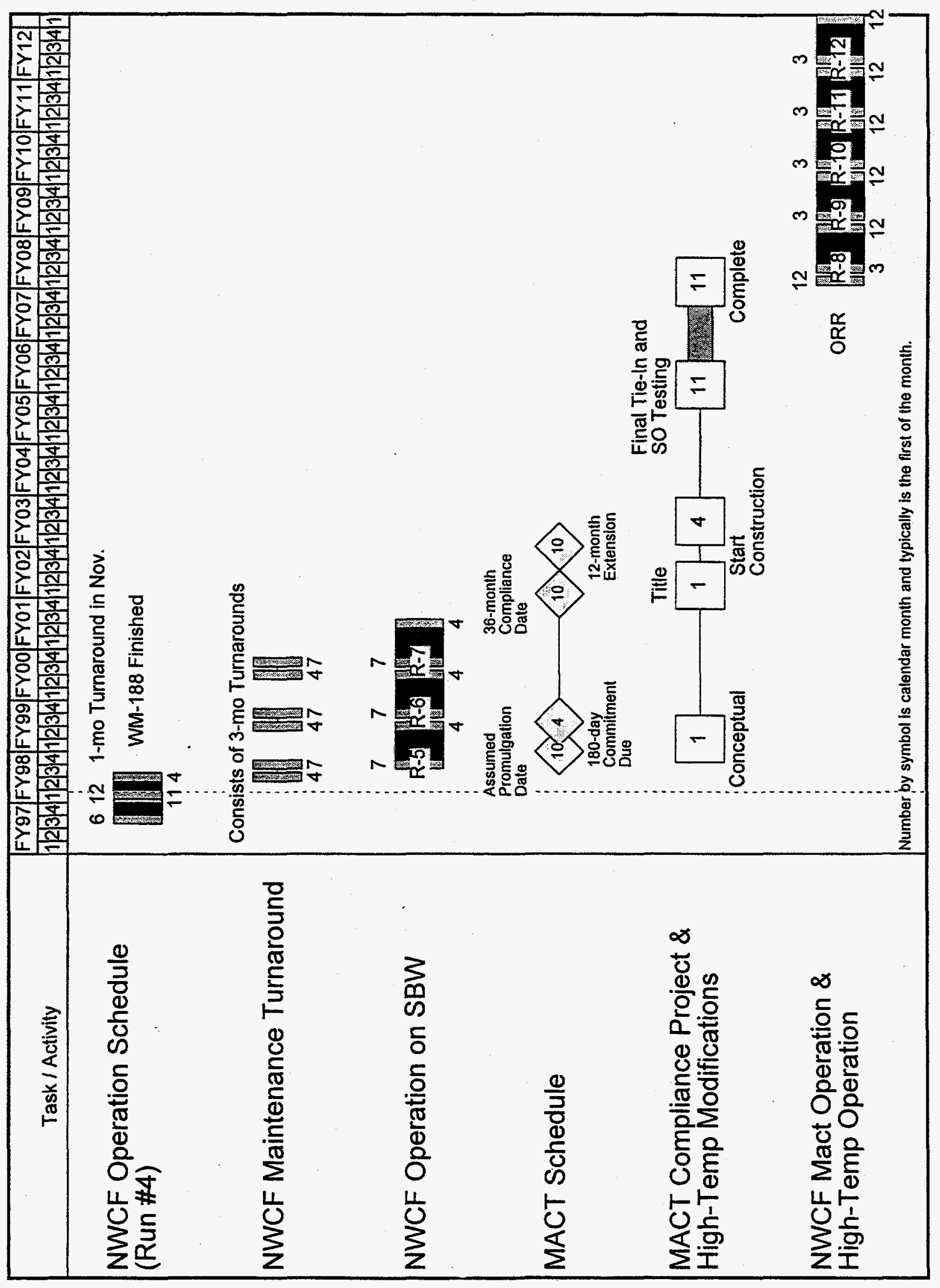

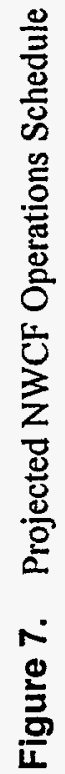


assumed that these modifications, combined with a trial burn at the beginning of operation, would complete requirements for a RCRA Part B permit.

- High-Temperature Modifications will be done to improve throughput for the NWCF.

The High-Temperature modification project is assumed to be accomplished in the same period as the MACT Compliance Project.

\section{New Waste Calcining Facility:}

A more active approach at running the calciner was developed and is reflected in the operating schedule, as described above. The new approach is to run shorter campaigns ( 9 months) with shorter, deliberately planned maintenance turnarounds ( 3 months) rather than running for as long as possible until a shutdown is absolutely required. This approach is currently being employed and is expected to result in less facility downtime and decreased waste generation due to NWCF maintenance activities. This approach was made possible because NWCF maintenance tasks no longer have to compete with maintenance and readiness activities for fuel processing facilities.

A gross feed rate and three net feed rates are assumed for waste processing based on different waste compositions and blending requirements. These rates are dependent on HLLWE operating assumptions for blending and concentrating wastes. An efficiency factor, based on historical performance, is used to reflect the percentage of time the facility is projected to operate at flowsheet rates. The volume of process liquid recycle to the feed and the other chemical additions constitute the difference between the gross feed rate and net feed rate to the calciner.

These assumptions are:

- Gross feed rate:

- Net waste feed rates:

- On-stream Factor:

- Percent recycle:
180 gallons per hour

$57 \mathrm{gal} / \mathrm{hr}$ for WM-188 HLLW, $32 \mathrm{gal} / \mathrm{hr}$ for normal SBW, $57 \mathrm{gal} / \mathrm{hr}$ for high-temperature SBW calcination

$75 \%$

$20 \%$

\section{Tank Farm Tanks and Inventory:}

- The inventory of stored liquid is as of September 30, 1997.

- Tank WM-188 contains the only HLLW; the remaining tanks contain SBW.

- Tank WM-180 is considered concentrated; all the other tanks' contents can be evaporated through the HLLWE, either individually or as a blend with another tank for a nominal 2:1 reduction in volume.

- Tank WM-182 is used to store segregated Type 2 waste through 2002 and Tank WM-190 is used to store Type 2 waste beyond that time. 


\section{High-Level Liquid Waste Evaporator:}

Increased attention to blending and concentration of wastes through the HLLWE was done. Thus more tanks are assumed to be dilute and evaporation will reduce the volume requiring calcination. Several tanks are assumed to be blended, but will require sampling and analysis for the final determination. In the past, WM-183 was blended with WM-189 and transferred to WM-188. This waste is being calcined now and is the last remaining HLW. The following are assumed:

- HLLWE operation during the 3-month NWCF downtimes.

- WM-185 blended with WM-187 and concentrated

- WM-181 blended with WM-184 and concentrated

- WM-183 concentrated without blending

- WM-186 concentrated without blending

- Newly generated Type 2 waste concentrated without blending

\section{Process Equipment Waste Evaporator:}

The Process Equipment Waste (PEW) evaporator system concentrated dilute waste streams in a batch wise operation. Administrative limitations have been imposed which have been challenged in the name of efficiency. Better operational throughput has been demonstrated and will be pursued. Though most projections are assumed to be on the order of $20: 1$ or $30: 1$, volume reduction of greater than $50: 1$ has been achieved.

\section{Liquid Waste Generation Projections:}

The liquid waste generation projections are based on baselines and goals, which have been established through team reviews with input by individuals responsible for the sources. Tracking and evaluation of the generated volumes coupled with innovative efforts to minimize future quantities has resulted in improvements in the projections. In 1996, a review team was assembled to examine the previous waste projections and was commissioned to establish goals for waste minimization efforts. A report was issued in July 1996 to document the goals (Reference 4). In September a new baseline was established to compare the goals against for performance measurement. The goals represented basically a 35\% reduction from the baseline. In 1997, a new analysis was done which established a new baseline and goals for minimization (Reference 5). The 1997 report values are more aggressive than the 1996 goals and baseline. These projections reflect advances across the ICPP by:

- eliminating waste at the source,

- processing wastes more efficiently through the PEW system,

- improved utilization of the HLLWE,

- innovative waste management within the Tank Farm for flushing tank heels,

- and the new NWCF processing approach and schedule (which were influential in lowering the volume projections returned to the Tank Farm from calciner operations). 
The 2006 Plan Case is based on the 1996 goals projections, Reference 4, whereas the December 1997 Case is based on the 1997 goals established in Reference 5. The new waste generation projections coupled with the new NWCF operating schedule have resulted in an overall change of $37 \%$ reduction in input from the 2006 Plan case to the December 1997 Case presented in this plan.

The wastes consist of two types and will be managed as two levels of concentration (thus four separate categories). Concentrated waste that is not deemed viable for further evaporation will be kept separate from dilute waste. Dilute waste may be stored in the Tank Farm separately and then processed through the HLLWE to both reduce the storage volume in the Tank Farm and to process more efficiently through the calciner. Concentrated and dilute waste of both types may exist:

- Type 1 wastes will require calcination.

- Type 2 wastes may be segregated and processed through some other means such as direct grouting or may be calcined.

\section{Waste volume to be processed:}

Overall changes result in a $23 \%$ reduction in the volume of waste, which must be processed through the Tank Farm in order to empty the tanks by December 2012. This $23 \%$ is based on the former estimate of 2.15 million gallons, which is a combination of existing inventory plus future generation. The new estimate is 1.66 million gallons, which is a combination of the existing inventory, reduced further by evaporation, plus lower future generation.

\subsection{Tank Management}

The basis for the Tank Farm Plan is the HLW treatment baseline plan as described in the 2006 Plan. In simple terms, the plan is to continue NWCF operation through approximately mid FY2001, upgrade the calciner to meet permitting and MACT requirements, perform start-up testing including a trial burn, and then operate the calciner until the Tank Farm is empty. The detailed NWCF operating schedule is provided in Figure 7.

The initial modeling (referred to as the 2006 Plan Case) for the Tank Farm was based on the waste generation projections from Reference 4 and historically used assumptions for waste blending and evaporation and for calciner turnaround periods. The results of this modeling are shown in Figure 8. (Detailed information on waste volume in individual tanks, as a function of time, for the 2006 Plan Case is provided in Appendix B.) At the end of 2012, approximately two tanks of liquid waste would remain in storage. This clearly would not meet the Settlement Agreement requirement to complete calcination of SBW by 2012 (calcination would actually complete in 2016) and would be unacceptable as a baseline plan for waste management at the ICPP.

To meet the 2012 Settlement Agreement requirement, more aggressive modeling assumptions were developed for waste blending, waste evaporation, and calciner operations. In addition, the 


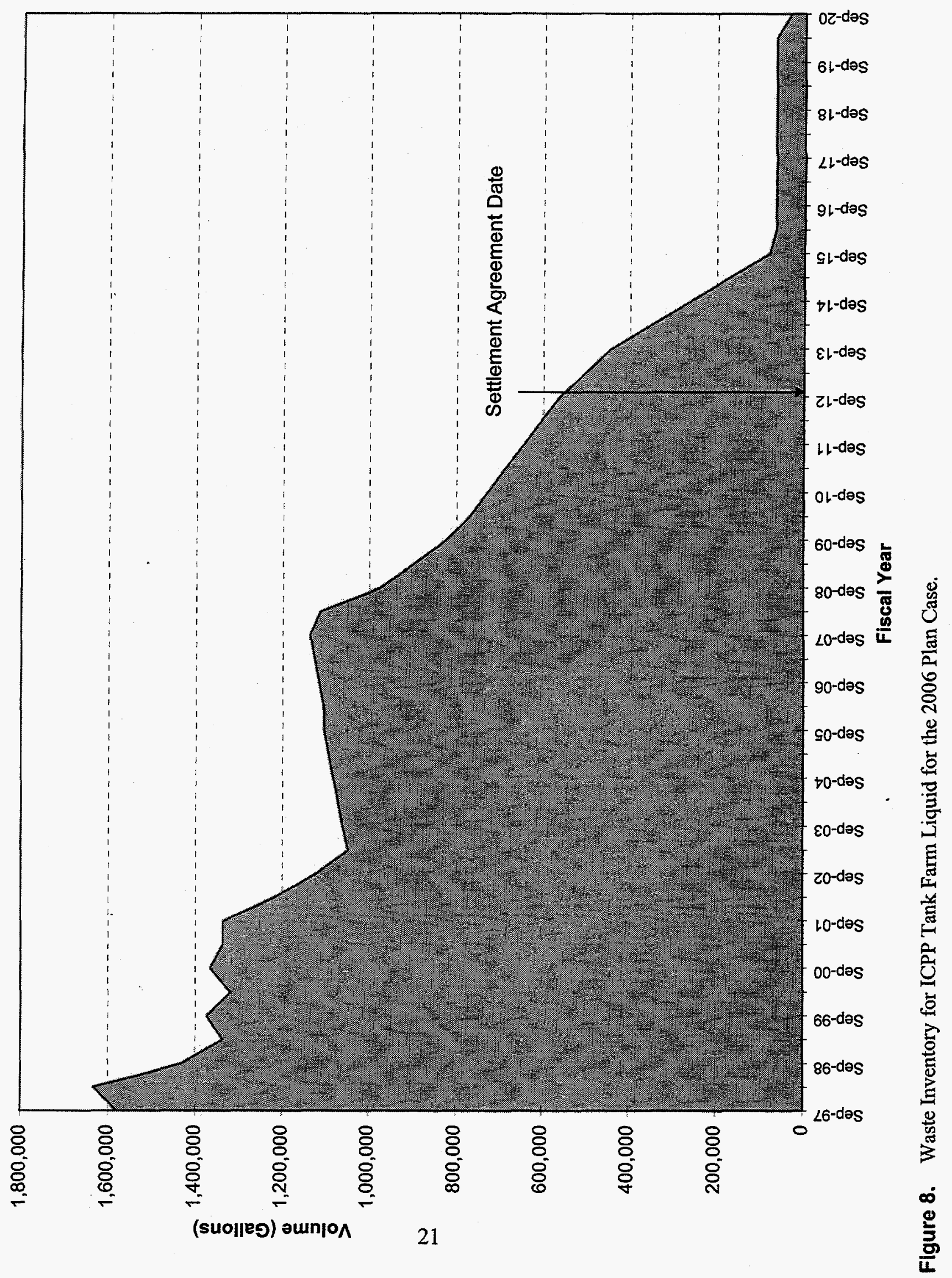


more aggressive waste minimization projections from Reference 5 were used in place of those from Reference 4. To further aid in the reduction of waste volume, it was assumed that Type 2 wastes (those not requiring calcination) could be treated by an alternate process, such as grouting. The results of this modeling (referred to as the December 1997 Case) are shown in Figure 9. All of the SBW is calcined by the end of 2011, which meets the Settlement Agreement requirement. (Detailed information on waste volume in individual tanks, as a function of time, for the December 1997 Case is provided in Appendix C.)

Since the December 1997 Case meets regulatory requirements and should be achievable with careful planning and sustained funding, all further planning details in this report are based on it. This case is the basis for the December 1997 PBS submission to DOE-HQ and is the proposed HLW planning baseline.

Each waste tank in the Tank Farm is unique in construction, history of use, and composition of waste. Each of these issues must be considered when developing a detailed operational plan. The following provides a summary of each tank's situation. Appendix D contains detailed graphs showing individual tank volumes and waste type as a function of time from when the tank was put in service to the present.

\section{WM-180}

This is one of the two oldest Tank Farm tanks at the ICPP and was put into service in 1954. It is contained in an octagonal, poured-in-place reinforced concrete vault that meets current seismic requirements. The tank is 50 feet in diameter. It is quite similar to the other Tank Farm tanks except that it is constructed of 347 stainless steel, rather than 304L, and its wall is 23 feet high rather than 21 feet high. This extra wall height gives this tank a nominal volume of 318,000 gallons rather than 300,000 gallons, but the operating volume is not normally allowed to exceed 285,000 gallons $^{\mathrm{d}}$. The tank is equipped with cooling coils.

The inlet piping does not meet RCRA secondary containment requirements; because of this, transfers to the tank are minimized and require special administrative approvals. The tank has been filled three times and has contained aluminum fuel reprocessing raffinate and SBW (Figure D1). The tank currently contains SBW that has been sampled and analyzed sufficiently to determine a calcination flowsheet. The waste is high in sodium and probably cannot be further concentrated. Once the tank is emptied, it will probably not be reused due to the inlet piping not having adequate secondary containment. The waste can be calcined at any time. Figure $\mathrm{Cl}$ shows the planned operations for Tank WM-180.

\footnotetext{
d The volume of liquid stored in a tank is limited to 285,000 gallons so that the contents of a leaking tank plus $5 \%$ transfer jet dilution can all fit into the 300,000-gallon spare tank.
} 


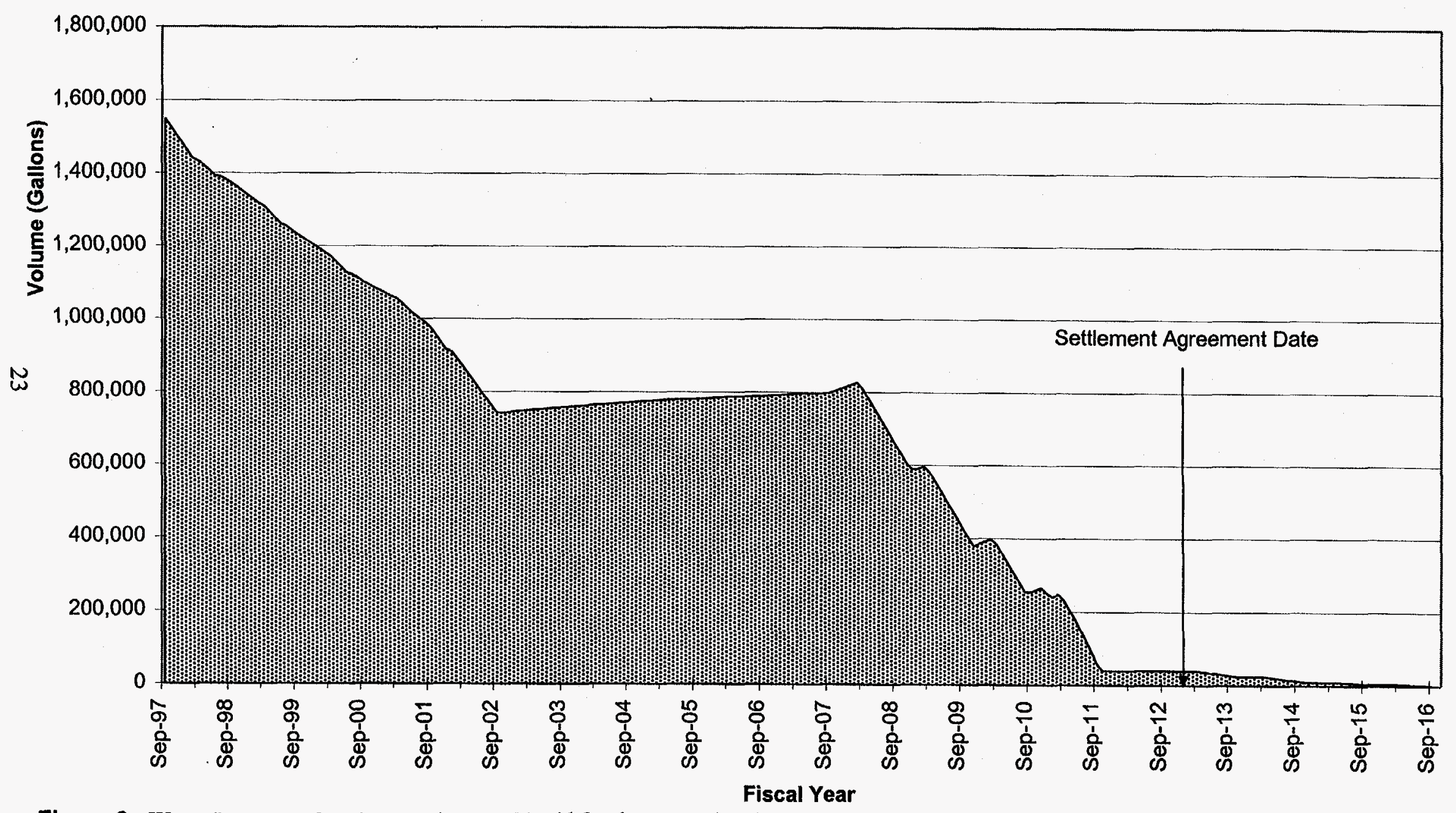

Figure 9. Waste Inventory for ICPP Tank Farm Liquid for the December 1997 Case. 


\section{WM-181}

This is one of the two oldest Tank Farm tanks at the ICPP and was put into service in 1953. It is contained in an octagonal, poured-in-place reinforced concrete vault that meets current seismic requirements. The tank is 50 feet in diameter. It is quite similar to the other Tank Farm tanks except that it is constructed of 347 stainless steel, rather than $304 \mathrm{~L}$, and its wall is 23 feet high rather than 21 feet high. This extra wall height gives this tank a nominal volume of 318,000 gallons rather than 300,000 gallons, but the operating volume is not normally allowed to exceed 285,000 gallons. The tank does not contain cooling coils. The inlet piping does not meet RCRA secondary containment requirements; because of this, transfers to the tank are minimized and require special administrative approvals. The tank has been filled four times and has contained only SBW waste (Figure D2). The tank currently contains SBW that has been sampled and analyzed sufficiently to determine a calcination flowsheet. This waste will be blended with WM184 and/or WM-186 waste, depending on future sample analyses, and concentrated in the HLLWE prior to calcination. This evaporation will take place after the WM-187/WM-185 waste evaporation. Once the tank is emptied, it will probably not be reused due to the inlet piping not having adequate secondary containment. Figure C2 shows the planned operations for Tank WM181.

\section{WM-182}

This tank was put into service in 1955. It is contained in an octagonal, pillar-and-panel concrete vault that is not as structurally robust as a monolithic design. The tank is 50 feet in diameter, is constructed of 304L stainless steel, and has a side wall that is 21 feet high. The tank has a nominal volume of 300,000 gallons, but the operating volume is not allowed to exceed 285,000 gallons. The piping meets RCRA secondary containment requirements and there are no restrictions on waste transfers to or from the tank. (The dimensions, material of construction, and piping configuration, described in the three preceding sentences, are the same for the remaining tanks addressed in this section.) The tank is equipped with cooling coils. The tank has been filled four times and has contained both aluminum and zirconium fuel reprocessing raffinates (Figure D3). The tank was emptied to heel level and the HLW heel was flushed from the tank and replaced with a SBW heel. The plan projects that approximately 4000 gallons will yet be transferred to WM-183 or WM-187, then the heel will be flushed further to reduce the radioactivity level and then the tank will be used for storing segregated ${ }^{e}$ Type 2 waste (waste that does not necessarily require calcination). This tank will be the first to be closed in conformance with RCRA in 2005. WM-182 and WM-183 will be closed together due to their interconnected piping that makes independent closure impractical, but also simplifies isolation of the tanks. These two tanks will be the most difficult to close. Successful closure of these two tanks should convince regulators that the method could also be used on the other tanks. Figure C3 shows the planned operations for Tank WM-182.

\section{WM-183}

This tank was put into service in 1958. It is contained in an octagonal, pillar-and-panel concrete vault that is not as structurally robust as a monolithic design. The tank is equipped with cooling

\footnotetext{
${ }^{\mathrm{e}}$ Waste segregation is discussed in Section IIIC. and Appendix E.
} 
coils. The tank has been filled three times and has contained aluminum fuel reprocessing raffinates, high fluoride decontamination solutions, and PEW evaporator and HLLWE (WC-114) bottoms (Figure D4). WM-183 has contained the greatest variety of wastes and will likely have more precipitated solids on its bottom than any other tank. This tank will continue to receive PEW evaporator bottoms until full. RCRA closure will occur along with WM-182 in approximately 2006. At that time (or earlier) its contents will be evaporated and transferred to WM-187 and the tank will be closed. Figure C4 shows the planned operations for Tank WM183.

\section{WM-184}

This tank was put into service in 1958. It is contained in an octagonal, pillar-and-panel concrete vault that is not as structurally robust as a monolithic design. The tank does not contain cooling coils. The tank has been filled once and has contained only PEW evaporator bottoms (Figure D5). Approximately 20,000 gallons freeboard has been retained in this tank for unplanned transfers. The waste in this tank will probably be evaporated, but must first be resampled to determine if the uranium content is too high for HLIWE limits. It is assumed to be evaporated along with WM-181 and the concentrate solution sent to WM-188 and WM-187. Once this tank is emptied, it will not be refilled. Figure C5 shows the planned operations for Tank WM-184.

\section{WM-185}

This tank was put into service in 1959. It is contained in an octagonal, pillar-and-panel concrete vault that is not as structurally robust as a monolithic design. The tank is equipped with cooling coils. The tank has been filled six times and has contained both aluminum and zirconium fuel reprocessing raffinates as well as high fluoride decontamination waste and $\mathrm{PEW}$ evaporator bottoms (Figure D6). The blending of WM-185 and WM-187 followed by concentration in the HLLWE and transfer to WM-189, which was occurring in January 1997 when the HLLWE was shut down, will continue to completion. When this is complete, WM-185 will contain approximately 100,000 gallons that will be fed to the NWCF without blending. When empty, this tank can be used as the designated spare tank if WM-190 is put into service; however, it will not be refilled under normal service. Figure C6 shows the planned operations for Tank WM- 185 .

\section{WM-186}

This tank was put into service in 1962. It is contained in an octagonal, pillar-and-panel concrete vault that is not as structurally robust as a monolithic design. The tank does not contain cooling coils. The tank has been filled two times and has contained aluminum reprocessing raffinate and PEW evaporator bottoms (Figure D7). The SBW in WM-186 is dilute and will require evaporation prior to calcination. Once this tank is emptied, it will not be refilled. Figure C7 shows the planned operations for Tank WM-186.

\section{WM-187}

This tank was put into service in 1959. It is contained in a square reinforced concrete vault that meets current seismic requirements. The tank is equipped with cooling coils. The tank has been filled five times and has contained both aluminum and zirconium fuel reprocessing raffinates as well as high fluoride decontamination waste and PEW evaporator bottoms (Figure D8). The SBW remaining in WM-187 is dilute and will be blended with WM-185 and concentrated, as 
described above, prior to calcination. Once it is emptied, it will be used to collect HLLWE concentrates. This tank must remain available through 2012. WM-187 will be RCRA closed together with WM-188, -189 , and -190 after 2012. Figure C8 shows the planned operations for Tank WM-187.

\section{WM-188}

This tank was put into service in 1963. It is contained in a square reinforced concrete vault which meets current seismic requirements. The tank is equipped with cooling coils. This tank has been filled five times and has contained zirconium fuel reprocessing raffinates as well as high fluoride decontamination waste and PEW evaporator bottoms (Figure D9). The blended waste remaining in WM-188 is the last of the HLW in the Tank Farm. Once it is emptied, WM-188 will be used to collect the concentrated waste from HLLWE operations blending WM-181 and WM-184 and wastes returned from NWCF operations. This tank must remain available through 2012 and will be RCRA closed along with the other square-vaulted tanks after 2012. Figure C9 shows the planned operations for Tank WM-188.

\section{WM-189}

This tank was put into service in 1966. It is contained in a square reinforced concrete vault which meets current seismic requirements. The tank is equipped with cooling coils. This tank has been filled five times and has contained zirconium fuel reprocessing raffinates as well as high fluoride decontamination waste and PEW evaporator bottoms (Figure D10). The waste currently in WM-189 is the HLLWE concentrate from the WM-185/-187 blend. This operation will continue to completion when the HLLWE begins operation again. This concentrate will be the next feed to NWCF when WM-188 is emptied. Once WM-189 is emptied, it will be used to collect HLLWE concentrate and PEW evaporator bottoms. This tank must remain available through 2012 and will be RCRA closed along with the other square-vaulted tanks after 2012. Figure C10 shows the planned operations for Tank WM- 189.

\section{WM-190}

This tank was never put into service, but was retained as the designated spare tank for use in emergencies. Over many years, approximately 7000 gallons of accumulated vault sump water and HLLW, that leaked through closed valves, collected in the tank. This waste was pumped from the tank in 1982 (Figure D11). The tank is currently estimated to contain only 500 gallons of solution. The tank is contained in a square reinforced concrete vault that meets current seismic requirements. The tank is equipped with cooling coils. This tank will be kept empty as long as possible to retain maximum use flexibility in future Tank Farm operations. This tank must remain available through 2012 and will be RCRA closed along with the other squarevaulted tanks after 2012. Use of this tank for segregation of Type 2 waste after 2002 was assumed in the December 1997 Case. Figure C11 shows the planned operations for Tank WM190.

\section{Detailed Tank Farm Operation Scenario for the December 1997 Case}

- December 1997 to April 1998 - Calcine waste from Tank WM-188 and empty it to heel level. 
- April 1998 to July 1998 - NWCF maintenance turnaround. Concentrate a blend of wastes from WM-185 and WM-187 in the HLLWE and send concentrate to WM-189. Begin blend of WM-181 and WM-184 and send concentrate to WM-188.

- July 1998 to April 1999 - Calcine waste from Tank WM-189 and WM-185.

- April 1999 to July 1999 - NWCF maintenance turnaround. Concentrate a blend of wastes from WM-181 and WM-184 in the HLLWE and send concentrate to WM-188.

- July 1999 to April 2000 - Calcine waste from Tank WM-185 and WM-180. September 1999-WM-185 will be empty through NWCF operation.

- April 2000 to July 2000 - NWCF maintenance turnaround. Concentrate waste from Tank WM-181 and WM-184 in the HLLWE and send concentrate to WM-188.

- July 2000 to April 2001 - Calcine waste from Tank WM-180. April 2001-WM-180 will be empty through NWCF operation.

- April 2001 to December 2007 - No calciner operation. MACT regulatory requirements will result in calciner shutdown in 2001 and the major facility modifications required to satisfy MACT and other permitting requirements will not be complete until 2007.

- April 2001 to August 2001 - Concentrate waste from Tanks WM-181 and WM-184 in the HLLWE and send concentrate to WM-187. August 2001-WM-181 and WM-184 will be empty through HLLWE operation.

- August 2001 to February 2002 - Concentrate waste from Tank WM-183 in the HLLWE and send concentrate to WM-187. February 2002-WM-183 will be empty through HLLWE operation.

- February 2002 to August 2002 - Concentrate waste from Tank WM-186 in the HLLWE and send concentrate to WM-189. August 2002 - WM-186 will be empty through HLLWE operation.

- August 2002 to November 2002- Concentrate segregated (Type 2) waste from Tank WM-182 in the HLLWE and send concentrate to WM-190. November 2002-WM-182 will be empty through HLLWE operation.

- November 2002 to December 2007-no evaporation or calcination in this period. Waste will be collected in WM-189 and WM-190 (Type 2). MACT compliance, High Temperature Modification Project, and Part B permit completed.

- December 2007 to March 2008 - NWCF start-up activities (Operational Readiness Review (ORR), emission test, cold operations, etc. $)^{\mathrm{f}}$

- March 2008 to December 2008 - Calcine waste from Tank WM-187.

- December 2008 to February 2009 - NWCF maintenance turnaround.

- March 2009 to December 2009 - Calcine waste from Tank WM-188.

- December 2009 to March 2010 - NWCF maintenance turnaround. No HLLWE operation.

- March 2010 to December 2010 - Calcine waste from Tank WM-189 and WM-188. September 2010 WM-189 will be empty through NWCF operation.

- December 2010 to March 2011 - NWCF maintenance turnaround. Evaporate the balance of dilute wastes from WM-187 to WM-188. February 2011 WM-187 will be empty through HLLWE operation.

\footnotetext{
${ }^{f}$ This schedule assumes the normal 12-18 month downtime following the emission test will be waived by the regulators and that operation concurrent with the evaluations will be allowed
} 
- March 2011 to November 2011 - Calcine waste from Tank WM-188 and WM-190. June 2011 WM-188 empty through NWCF operation. November 2011 WM-190 empty through NWCF operation.

The results of this scenario are shown in Figure 9. At the end of FY-2011, there is no waste in storage in the Tank Farm. This scenario completes the 2012 Settlement Agreement milestone approximately a year ahead of schedule.

\subsection{Liquid Waste Segregation}

Wastes generated at the INEEL, which ultimately are stored in the ICPP Tank Farm, can be divided into two waste types (Type 1 or Type 2) depending on the source and the required follow-on treatment. The Type 1 wastes are low activity liquid wastes that are generated during treatment of wastes associated with the past fuel reprocessing operations. These wastes require calcination or radionuclide separation for treatment to empty these wastes from the Tank Farm (e.g. HLLWE concentrate from evaporation of the sodium bearing waste now stored in the Tank Farm and wastes returned to the Tank Farm from NWCF operations).

The Type 2 wastes are low activity liquid wastes that are generated by operations that are not associated with the treatment of wastes resulting from past fuel reprocessing operations. These wastes do not require calcination or radionuclide separation and could be grouted directly (e.g. liquid wastes from the fuel storage basin water treatment and wastes from non-ICPP facilities).

Since the Settlement Agreement deadline to calcine all SBW by 2012 may be difficult to meet, it is desirable to remove as much of the waste load as possible from the calciner. One method of doing this is to segregate the Type 2 waste and treat it by a process other than calcination, such as grouting. Because these wastes are presently being generated and will continue to be generated, a Waste Segregation Plan was developed, which starts the waste segregation as soon as possible. It provides the optimum waste segregation, which will enhance waste minimization efforts and allows flexibility to maximize waste processing to empty the Tank Farm in accordance with the Settlement Agreement. It provides several years accumulation of feed for grouting (or other treatment) that would otherwise have to be either calcined or separated if it was blended with the Type 1 waste as is presently done. This segregation will not impact or limit any waste treatment options. The HLLWE and NWCF could continue to be used, the new planned waste treatment facilities could be used, or different plans could be developed for the future waste treatment. The waste segregation plan (see Appendix E for a copy of the plan) outlines a method of collecting and segregating the two waste types as they are generated, processed, and stored.

\subsection{Tank Heelout and Closure}

A detailed tank heelout and closure plan has not been developed, since many of the issues must be negotiated with the regulators as part of the approval process for the closure plan. However, the basic plan is well understood:

- Empty each tank of waste as much as possible using existing installed equipment. 
- Adjust and/or flush the heel using chemicals, water, or low-activity waste, as necessary, so that it can be effectively immobilized (probably by grouting).

- Add non-radioactive grout to the tank.

- Pump as much of the liquid waste heel from the tank as possible as the grout displaces the heel.

- Cover the entire tank bottom with grout.

- Solidify any remaining liquid with dry grouting materials.

- Add a second grout layer to insure immobilization of all original tank contents.

- Fill the area between the tank and vault with clean grout, including the area above the tank to form a cap. This filling will be done in a controlled manner to prevent tank collapse.

- Complete RCRA closure for the tank.

This closure method results in any residual tank contents being immobilized in grout and then surrounded by a concrete shell. The void remaining inside the tank could then be filled with clean materials (such as grout), low-level radioactive materials (such as low activity waste grout), or even left empty.

Current plans call for grouting the heels in two tanks by 2006. Since permits, contracts, equipment, personnel, training, and procedures would be in place, it would be logical to continue to grout the heels in the remaining tanks as well. Using this assumption, Figure 10 shows the closure sequence and schedule for the eleven Tank Farm tanks. Appendix C graphs show an assumed 36,000 gallons of grout volume in each tank as a result of tank heelout activities. Tank WM-182 would be closed first because it is a pillar and panel vaulted tank and because it probably has less precipitated solids than most of the other tanks, since it has contained only HLW. Tank WM-183 would be closed second because it is tied into WM-182 with its piping requiring them to be closed more or less together. In addition, WM-183 probably contains the most possible precipitated solids since it has stored a greater assortment of wastes than any other tank and because of this, will be the most difficult tank to treat. Once these two tanks are closed, the procedures and equipment should be adequately developed for closure of the remaining tanks to proceed.

Following these two tanks, the remaining pillar and panel vaulted tanks would be closed sequentially. WM-180 and WM-181 would be closed next, since they are the oldest monolithically vaulted tanks. WM-187 through WM-190 would be closed last, since they are the newest monolithically vaulted tanks.

Two years are scheduled for closure of each tank, with a one-year overlap between tanks. The schedule for Tank WM-182 is longer to provide the extra time required for the initial technical development, regulatory requirements, project management, and operational systems. Once these items are provided initially, the long schedule is not required for the remaining tanks.

The schedule shown in Figure 10 was developed based on the requirements to close two tanks by 2006. However, the closure schedule for the pillar and panel vaulted tanks could be accelerated by as much as three years if the funding was accelerated. 


\subsection{New Tankage}

The current plan calls for constructing new RCRA compliant liquid waste tanks for storing newly generated waste that is produced after 2012. These tanks would also be used in conjunction with operation of the immobilization facility that is planned to come on line in 2020 . The system would consist of three tanks of 100,000-gallon capacity each. The tanks would be available for use by 2011 to provide for a smooth transition from using the existing tanks.

\section{Conclusions}

Using the assumptions embedded in the 2006 Plan Case as described in The INEEL Environmental Management Accelerating Cleanup: Focus on 2006, Discussion Draft, (June 1997), combined with the NWCF MACT upgrade schedule, all of the SBW would not be calcined by December 31, 2012 as required by the Idaho Settlement Agreement. Using the more aggressive assumptions embedded in the December 1997 Case as described in the body of this report, all of the SBW would be calcined in time to meet the Settlement Agreement.

In the December 1997 Case, the first tank (WM-182) would be closed in 2005 and closure of all eleven of the large HLW storage tanks would be complete by 2016. 


\section{0}

\begin{tabular}{|c|c|c|c|c|c|c|c|c|c|c|c|c|c|c|c|c|c|c|}
\hline Fiscal Year & 2000 & 2001 & 2002 & 2003 & 2004 & 2005 & 2006 & 2007 & 2008 & 2009 & 2010 & 2011 & 2012 & 2013 & 2014 & 2015 & 2016 & 2017 \\
\hline \multicolumn{19}{|l|}{ Tank WM-180 } \\
\hline \multirow{2}{*}{\multicolumn{19}{|c|}{ Tank WM-181 }} \\
\hline \multirow{2}{*}{\multicolumn{19}{|c|}{$\frac{\text { Tank WM-182 }}{\text { Tank WM-183 }}$}} \\
\hline \multirow{2}{*}{\multicolumn{19}{|c|}{\begin{tabular}{|l} 
Tank WM-183 \\
Tank WM-184
\end{tabular}}} \\
\hline & & & & & & & & & & & & & & & & & & \\
\hline \multicolumn{19}{|l|}{\begin{tabular}{|l} 
Tank WM-184 \\
Tank WM-185
\end{tabular}} \\
\hline \multicolumn{19}{|l|}{ Tank WM-186 } \\
\hline \multicolumn{19}{|l|}{ Tank WM-187 } \\
\hline \multirow{2}{*}{\multicolumn{19}{|c|}{\begin{tabular}{|l} 
Tank WM-188 \\
Tank WM-189
\end{tabular}}} \\
\hline \multirow{2}{*}{\multicolumn{19}{|c|}{\begin{tabular}{|l} 
Tank WM-189 \\
Tank WM-190 \\
\end{tabular}}} \\
\hline & & & & & & & & & & & & & & & & & & \\
\hline & & & & & & & & & & & & & & & & & & \\
\hline
\end{tabular}

Figure 10. Tank Farm Heelout and Closure Schedule. 


\section{Recommendations}

Because the December 1997 Case meets the Settlement Agreement and other compliance milestones and appears to be achievable, this plan should be followed for management of the INEEL HLW. The major elements of the plan which must be adhered to are:

- Operation of the calciner into the third quarter of FY-2001 before shutting down due to permitting/MACT requirements

- Operation of the calciner on a 9-month operating/3-month turnaround schedule

- Aggressive blending and concentration of all liquid wastes to maximize calciner effectiveness

- Implementation of high temperature modifications to the calciner to increase SBW throughput

- Upgrade of the calciner after 2001 to adhere to MACT requirements with hot startup in 2008

- Aggressive implementation of waste minimization plans as described in Reference 5

- Segregation of Type 2 waste followed by grouting (or other treatment) to reduce the waste load to the calciner 


\section{References}

1. W. B. Palmer, et al., ICPP Tank Farm Systems Analysis, WINCO-1192, Westinghouse Idaho Nuclear Company, Idaho Falls, Idaho, January 1994.

2. J. A. Murphy, et al., ICPP Radioactive Liquid and Calcine Waste Technologies Evaluation Final Report and Recommendation, INEL-94/0119, Idaho National Engineering Laboratory, Idaho Falls, Idaho, April 1995.

3. The INEEL Environmental Management Accelerating Cleanup: Focus on 2006, Discussion Draft, PLN-177, June 1997.

4. J. L. Tripp, Radioactive Liquid Waste Generation Goals at the ICPP, INEL-96/0246, Lockheed Martin Idaho Technologies Company, July 1996.

5. J. L. Tripp, Idaho Chemical Processing Plant Waste Minimization Plan, INEL/EXT-9700988, Lockheed Martin Idaho Technologies Company, August 1997.

6. Settlement Agreement between the Department of Energy (Thomas P. Grumbly), Naval Nuclear Propulsion Program (Bruce DeMars), and the State of Idaho (Phillip E. Batt). Consent Order signed October 17, 1995 by Edward J. Lodge.

7. T. Wichmann, N. Brooks, and M. Heiser, Regulatory Analysis and Proposed Path Forward for the Idaho National Engineering Laboratory High-level Waste Program - Revision 1, DOE/ID-10544, Idaho Falls, Idaho, October 1996.

8. Idaho National Engineering Laboratory Site Treatment Plan, DOE/ID-10519, Idaho Falls, Idaho, September 26, 1995.

9. Feasibility Study Report for NWCF MACT Compliance Facility, INEL/INT-97-00992, Lockheed Martin Idaho Technologies Company, November 1997. 


\section{APPENDIX A}

\section{TANK FARM WASTE CONCENTRATIONS}




\section{APPENDIX A}

\section{TANK FARM WASTE CONCENTRATIONS}

Table A1. Tank Farm Waste Chemical Concentrations A-2

Table A2. Tank Farm Waste Radionuclide Concentrations A-3

Table A3. Tank Farm Waste Actinide Concentrations. A-4 
Table A1. Tank Farm Waste Chemical Concentrations.

\begin{tabular}{|c|c|c|c|c|c|c|c|c|c|c|c|c|}
\hline WASTE TANK & & WM-180 & WM-181 & WM-182 & WM-183 & WM-184 & WM-185 & WM-186 & WM-187 & WM-188 & WM-189 & WM-190 \\
\hline DENSITY & $\mathbf{g} / \mathbf{m l}$ & 1.28 & 1.16 & 1.23 & 1.24 & 1.27 & 1.28 & 1.18 & 1.16 & 1.32 & 1.31 & \\
\hline $\operatorname{ACID}\left(\mathbf{H}^{+}\right)$ & M & 1.20 & 1.89 & 0.85 & 2.03 & 0.45 & 1.61 & 1.57 & 1.98 & 2.79 & 2.62 & 0.02 \\
\hline NITRATE $\left(\mathrm{NO}_{3}\right)$ & $\mathbf{M}$ & 4.80 & 3.87 & 4.26 & 5.52 & 4.87 & 5.29 & 3.08 & 3.37 & 6.16 & 6.47 & 0.02 \\
\hline ALUMINUM (Al) & M & 0.66 & 0.23 & 1.26 & 0.65 & 0.85 & 0.72 & 0.37 & 0.54 & 0.87 & 1.04 & \\
\hline BORON (B) & $\mathbf{M}$ & 0.011 & 0.016 & 0.009 & 0.014 & 0.007 & 0.018 & 0.021 & 0.013 & 0.039 & 0.027 & \\
\hline CADMIUM (Cd) & $\underline{M}$ & 0.0008 & 0.0055 & 0.0021 & 0.0015 & 0.0002 & $<0.002$ & 0.0018 & 0.0052 & 0.0095 & 0.0060 & \\
\hline CALCIUM (Ca) & $\underline{\mathbf{M}}$ & 0.036 & 0.046 & & 0.044 & 0.012 & 0.071 & 0.066 & 0.043 & 0.156 & 0.096 & \\
\hline CHLORIDE (Cl) & $\mathbf{M}$ & 0.0326 & 0.0126 & 0.0105 & 0.0116 & 0.0453 & 0.0316 & 0.0211 & 0.0022 & 0.0154 & 0.0220 & 0.0003 \\
\hline CHROMIUM (Cr) & $\underline{\mathbf{M}}$ & 0.004 & 0.003 & 0.001 & 0.017 & 0.002 & 0.005 & & 0.002 & 0.013 & 0.006 & \\
\hline FLUORIDE (F) & $\mathbf{M}$ & 0.004 & 0.094 & 0.084 & 0.056 & 0.042 & 0.168 & 0.042 & 0.232 & 0.318 & 0.350 & 0.007 \\
\hline IRON (Fe) & $\mathbf{M}$ & 0.019 & 0.013 & 0.021 & 0.061 & 0.021 & 0.022 & 0.019 & 0.020 & 0.056 & 0.035 & \\
\hline LEAD (Pb) & $\underline{\mathbf{M}}$ & 0.0015 & 0.0011 & & 0.0016 & 0.0012 & 0.0010 & & & 0.0012 & & \\
\hline MANGANESE (Mn) & $\mathbf{M}$ & & 0.014 & & 0.014 & 0.009 & 0.020 & & & & & \\
\hline MERCURY (Hg) & $\underline{\mathbf{M}}$ & 0.00102 & 0.0004737 & & 0.0028 & 0.0015789 & 0.0041 & & 0.0008 & 0.0078 & 0.0036 & \\
\hline MOLYBDENUM (Mo) & $\underline{\mathbf{M}}$ & & 0.0005 & & 0.0007 & 0.0005 & 0.0005 & & & & & \\
\hline NICKEL (Ni) & $\mathbf{M}$ & 0.0017 & 0.0013 & & 0.0072 & 0.0013 & 0.0016 & & & 0.0056 & & \\
\hline PHOSPHATE $\left(\mathrm{PO}_{4}\right)$ & $\mathbf{M}$ & & 0.006 & & & 0.025 & 0.003 & & & 0.0004 & & \\
\hline POTASSIUM (K) & $\underline{\mathbf{M}}$ & 0.19 & 0.15 & 0.003 & 0.10 & 0.14 & 0.20 & 0.17 & 0.02 & 0.15 & 0.15 & \\
\hline SODIUM (Na) & $\underline{\mathbf{M}}$ & 2.11 & 0.95 & 0.02 & 0.81 & 2.11 & 1.47 & 1.01 & 0.18 & 0.78 & 1.14 & \\
\hline SULFATE $\left(\mathrm{SO}_{4}\right)$ & $\underline{\mathbf{M}}$ & 0.034 & 0.025 & 0.029 & 0.069 & 0.075 & 0.045 & 0.035 & 0.011 & 0.037 & 0.031 & \\
\hline ZIRCONIUM (Zr) & $\underline{\mathbf{M}}$ & $<0.0012$ & 0.005 & 0.011 & $<0.0016$ & & 0.010 & & 0.024 & 0.027 & 0.032 & \\
\hline
\end{tabular}


Table A2. Tank Farm Waste Radionuclide Concentrations.

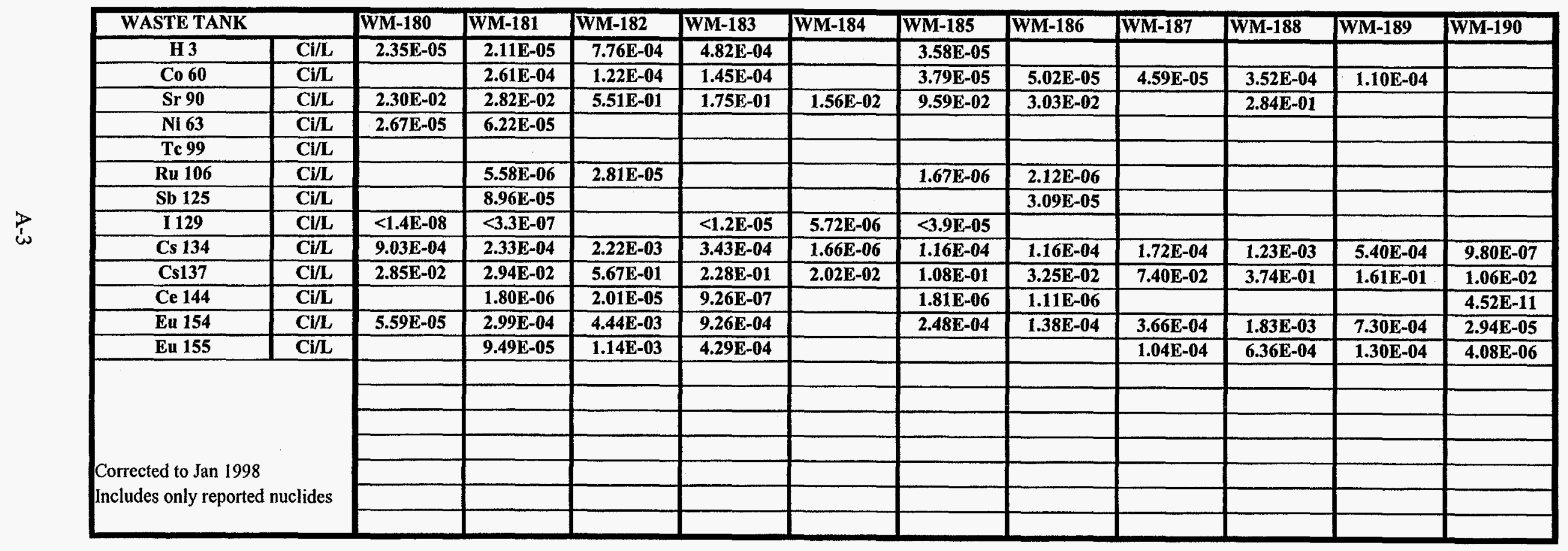


Table A3. Tank Farm Waste Actinide Concentrations.

\begin{tabular}{|c|c|c|c|c|c|c|c|c|c|c|c|c|}
\hline WASTE TANK & & WM-180 & WM-181 & WM-182 & WM-183 & |WM-184 & WM-185 & WM-186 & WM-187 & WM-188 & WM-189 & WM-190 \\
\hline U 234 & $\mathrm{Ci} / \mathrm{L}$ & $5.61 \mathrm{E}-07$ & 8.53E-07 & $1.98 \mathrm{E}-06$ & $6.28 \mathrm{E}-07$ & 8.23E-07 & $1.31 \mathrm{E}-06$ & $9.77 \mathrm{E}-07$ & $3.16 \mathrm{E}-08$ & $6.39 \mathrm{E}-07$ & $9.85 \mathrm{E}-07$ & \\
\hline U 235 & $\mathbf{C i} / \mathbf{L}$ & $1.54 \mathrm{E}-08$ & $2.14 \mathrm{E}-08$ & $5.73 \mathrm{E}-08$ & $2.65 \mathrm{E}-08$ & $2.26 \mathrm{E}-08$ & $2.74 \mathrm{E}-08$ & $2.27 \mathrm{E}-08$ & $7.11 \mathrm{E}-10$ & $2.59 \mathrm{E}-08$ & $2.07 \mathrm{E}-08$ & \\
\hline U 236 & $\mathrm{Ci} / \mathrm{L}$ & $7.36 \mathrm{E}-09$ & $7.56 \mathrm{E}-08$ & 2.13E-07 & $2.57 \mathrm{E}-08$ & $1.43 \mathrm{E}-08$ & $6.09 \mathrm{E}-08$ & $5.85 \mathrm{E}-08$ & $3.18 \mathrm{E}-09$ & $2.97 \mathrm{E}-08$ & $4.77 \mathrm{E}-08$ & \\
\hline U 238 & $\mathrm{Ci} / \mathrm{L}$ & $9.37 \mathrm{E}-09$ & 2.11E-08 & $1.08 \mathrm{E}-09$ & $3.00 \mathrm{E}-08$ & $9.16 \mathrm{E}-09$ & 2.47E-08 & $5.15 \mathrm{E}-08$ & 2.08E-12 & 2.77E-08 & $1.80 \mathrm{E}-08$ & \\
\hline Np 237 & $\mathrm{Ci} / \mathrm{L}$ & 4.34E-07 & $1.93 \mathrm{E}-07$ & $2.16 \mathrm{E}-06$ & 7.72E-07 & 4.60E-07 & $1.44 \mathrm{E}-05$ & 2.90E-07 & $5.67 \mathrm{E}-07$ & $1.61 \mathrm{E}-06$ & $1.11 \mathrm{E}-05$ & \\
\hline Pu 238 & $\overline{C i} / \mathrm{L}$ & 3.47E-04 & $6.15 \mathrm{E}-04$ & $2.57 \mathrm{E}-03$ & $6.59 \mathrm{E}-04$ & $6.59 \mathrm{E}-04$ & $8.39 \mathrm{E}-04$ & $2.32 \mathrm{E}-04$ & $1.99 \mathrm{E}-03$ & 3.77E-03 & $2.82 \mathrm{E}-03$ & \\
\hline Pu 239 & $\mathrm{Ci} / \mathrm{L}$ & $5.65 \mathrm{E}-05$ & $1.30 \mathrm{E}-05$ & $2.85 \mathrm{E}-04$ & $2.40 \mathrm{E}-04$ & $8.30 \mathrm{E}-05$ & $7.52 \mathrm{E}-05$ & $3.99 \mathrm{E}-05$ & $1.04 \mathrm{E}-05$ & 2.39E-04 & $6.62 \mathrm{E}-05$ & \\
\hline Pu 240 & $\mathrm{Ci} / \mathrm{L}$ & $1.69 \mathrm{E}-05$ & 3.65E-06 & $1.64 \mathrm{E}-05$ & $1.88 \mathrm{E}-05$ & $3.40 \mathrm{E}-05$ & $2.05 \mathrm{E}-05$ & $9.86 \mathrm{E}-06$ & 2.34E-06 & 2.11E-05 & $1.75 \mathrm{E}-05$ & \\
\hline Pu 241 & $\mathrm{Ci} / \mathrm{L}$ & $3.18 \mathrm{E}-04$ & $2.75 \mathrm{E}-04$ & $6.10 \mathrm{E}-04$ & $5.61 \mathrm{E}-04$ & $4.47 \mathrm{E}-04$ & $9.08 \mathrm{E}-04$ & $1.75 \mathrm{E}-04$ & $8.69 \mathrm{E}-04$ & $1.90 \mathrm{E}-03$ & $1.63 \mathrm{E}-03$ & \\
\hline $\mathrm{Pu} 242$ & $\mathrm{Ci} / \mathrm{L}$ & $1.27 \mathrm{E}-08$ & $8.63 \mathrm{E}-09$ & $1.94 \mathrm{E}-08$ & $5.53 \mathrm{E}-08$ & $1.00 \mathrm{E}-08$ & $2.44 \mathrm{E}-08$ & 4.17E-09 & $5.93 \mathrm{E}-09$ & $6.05 \mathrm{E}-08$ & $2.43 \mathrm{E}-08$ & \\
\hline Am 241 & $\mathrm{Ci} / \mathrm{L}$ & $5.59 \mathrm{E}-04$ & $2.08 \mathrm{E}-04$ & $5.02 \mathrm{E}-04$ & $7.48 \mathrm{E}-04$ & $2.20 \mathrm{E}-04$ & $5.59 \mathrm{E}-04$ & $2.10 \mathrm{E}-04$ & $4.58 \mathrm{E}-04$ & $1.42 \mathrm{E}-03$ & $9.14 \mathrm{E}-04$ & \\
\hline & & & & & & & & & & & & \\
\hline \multirow{3}{*}{\multicolumn{2}{|c|}{$\begin{array}{l}\text { Corrected to Jan } 1998 \\
\text { Includes only reported nuclides }\end{array}$}} & & & & & & & & & & & \\
\hline & & & & & & & & & & & & \\
\hline & & & & & & & & & & & & \\
\hline
\end{tabular}




\section{APPENDIX B}

\section{DETAILED WASTE TANK OPERATIONS FOR THE 2006 PLAN CASE}




\section{APPENDIX B}

\section{DETAILED WASTE TANK OPERATIONS FOR THE 2006 PLAN CASE}

Figure B1. Tank WM-180 Planned Operations ……….............................................

Figure B2. Tank WM-181 Planned Operations ...............................................................3

Figure B3. Tank WM-182 Planned Operations …………...............................................

Figure B4. Tank WM-183 Planned Operations ................................................................ B-5

Figure B5. Tank WM-184 Planned Operations .......................................................6-6

Figure B6. Tank WM-185 Planned Operations .............................................................

Figure B7. Tank WM-186 Planned Operations .............................................................8-8

Figure B8. Tank WM-187 Planned Operations ............................................................. B-9

Figure B9. Tank WM-188 Planned Operations ..............................................................B-10

Figure B10. Tank WM-189 Planned Operations .............................................................-11

Figure B11. Tank WM-190 Planned Operations ............................................................ 


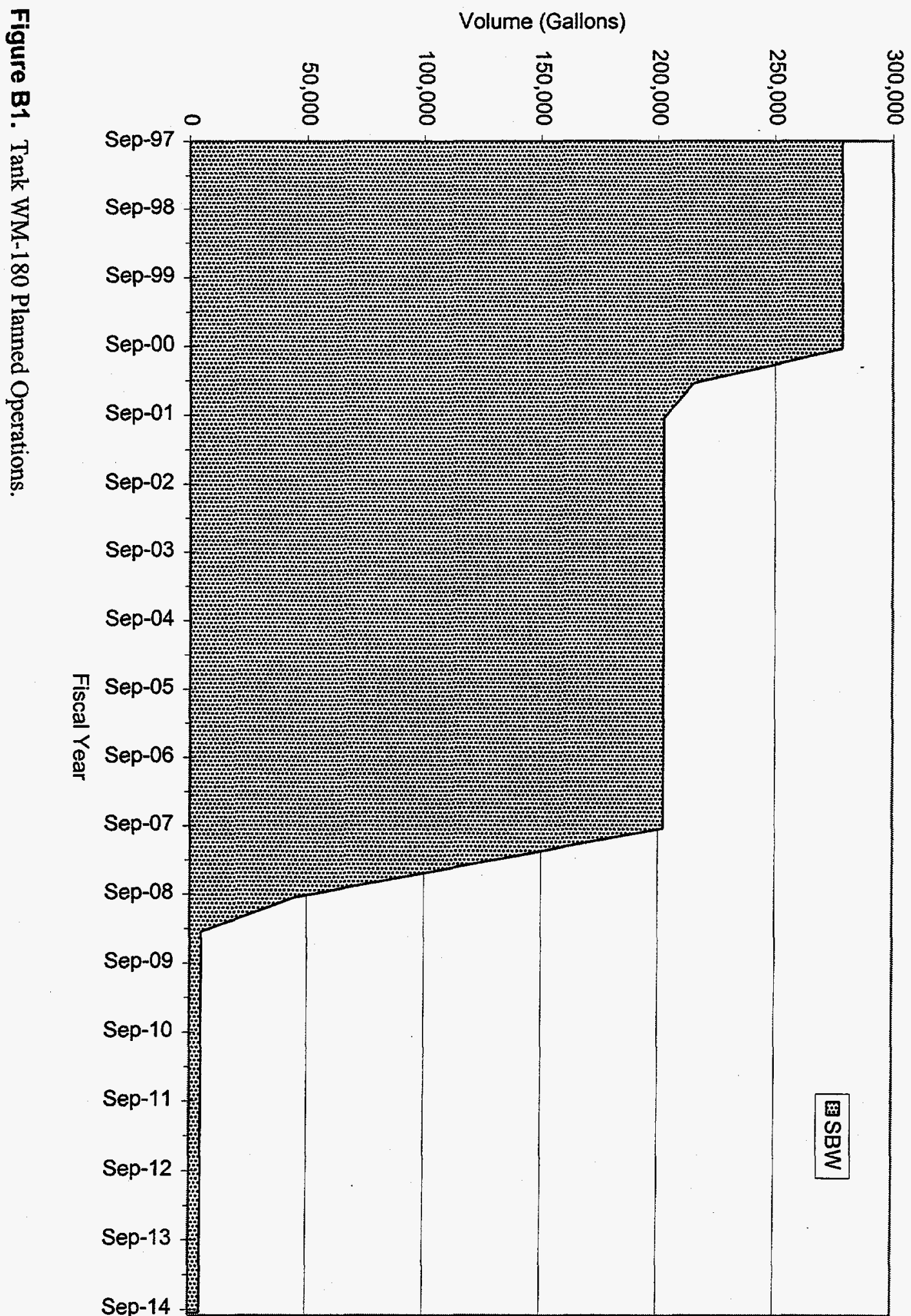




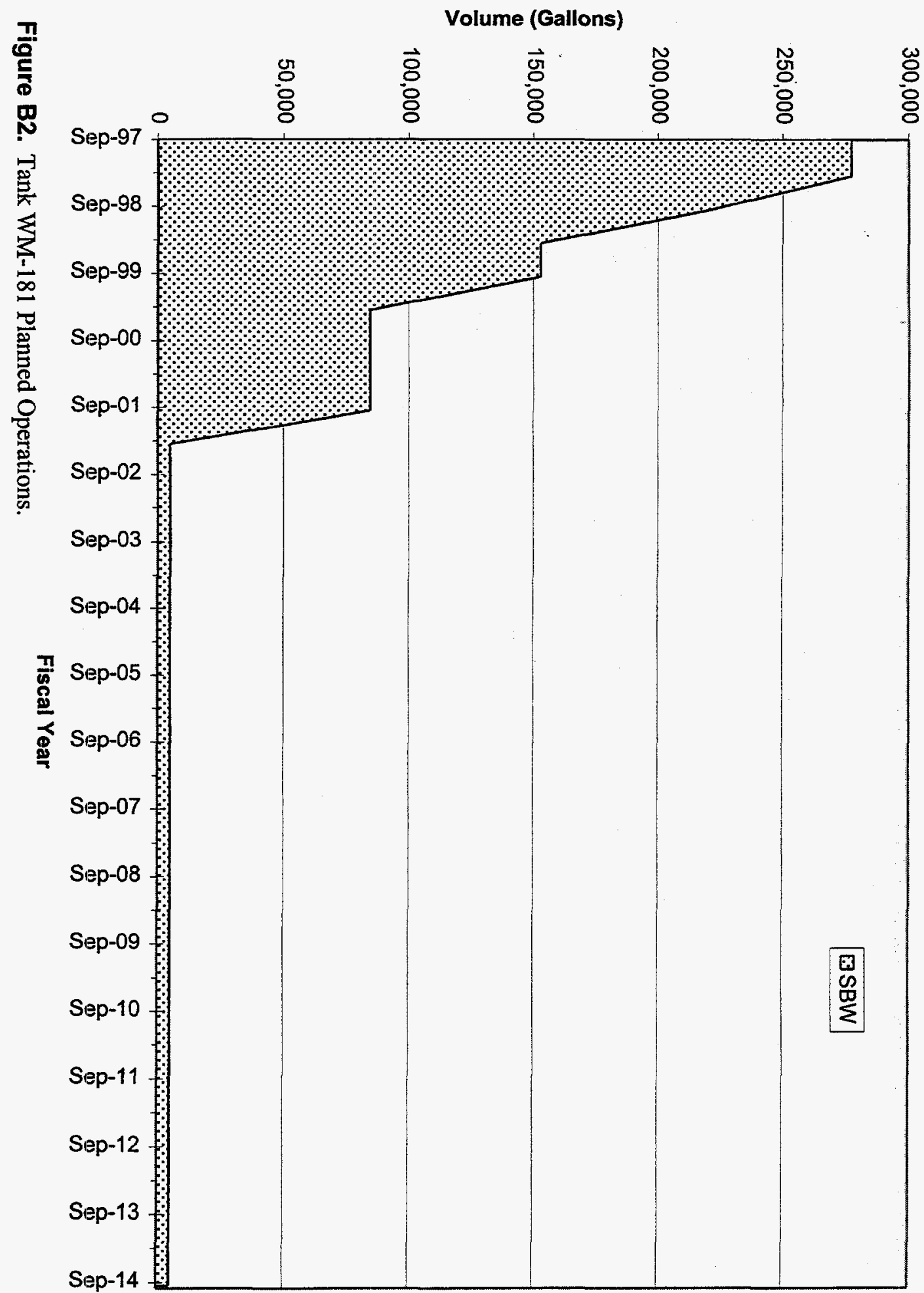




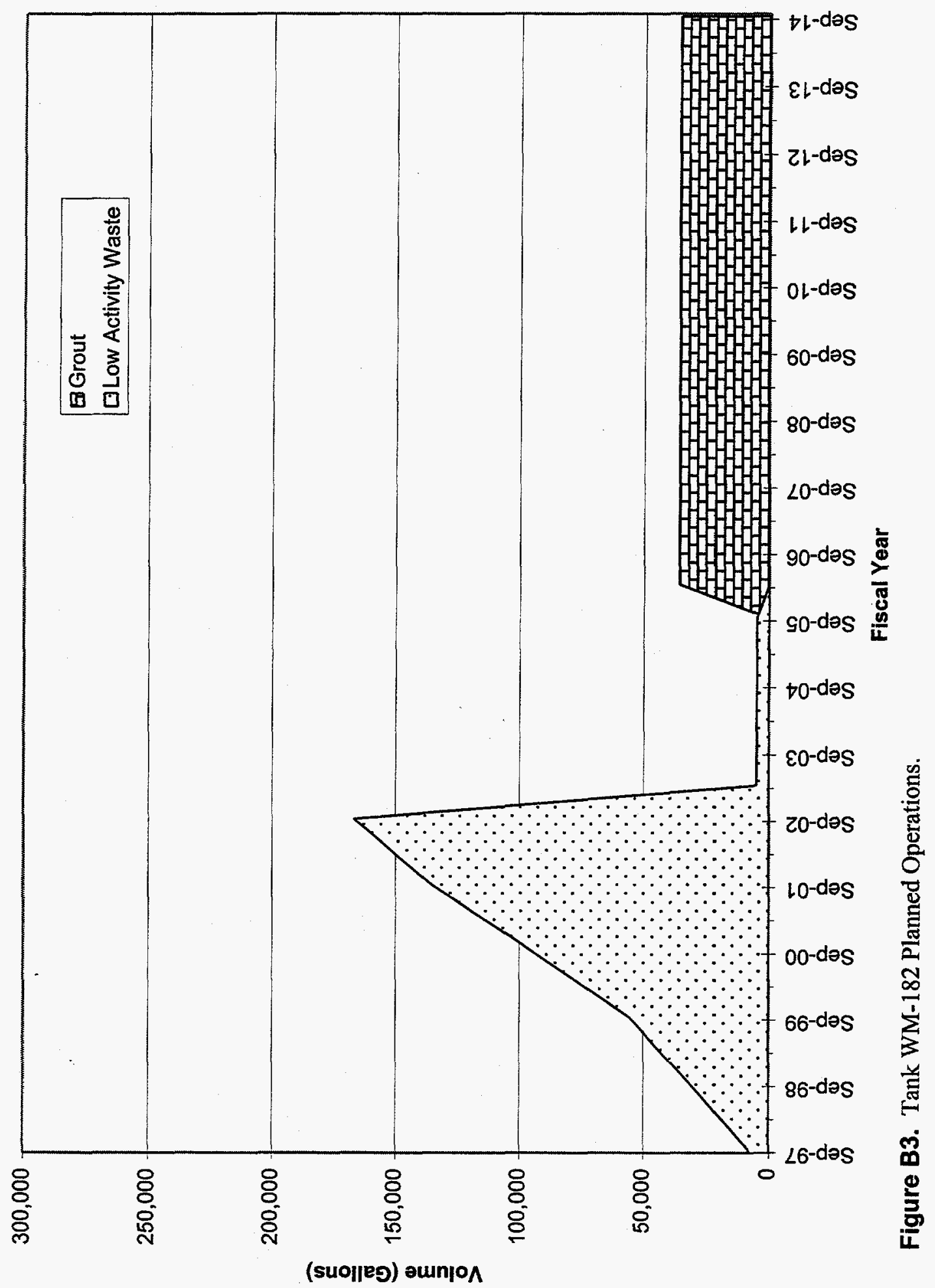




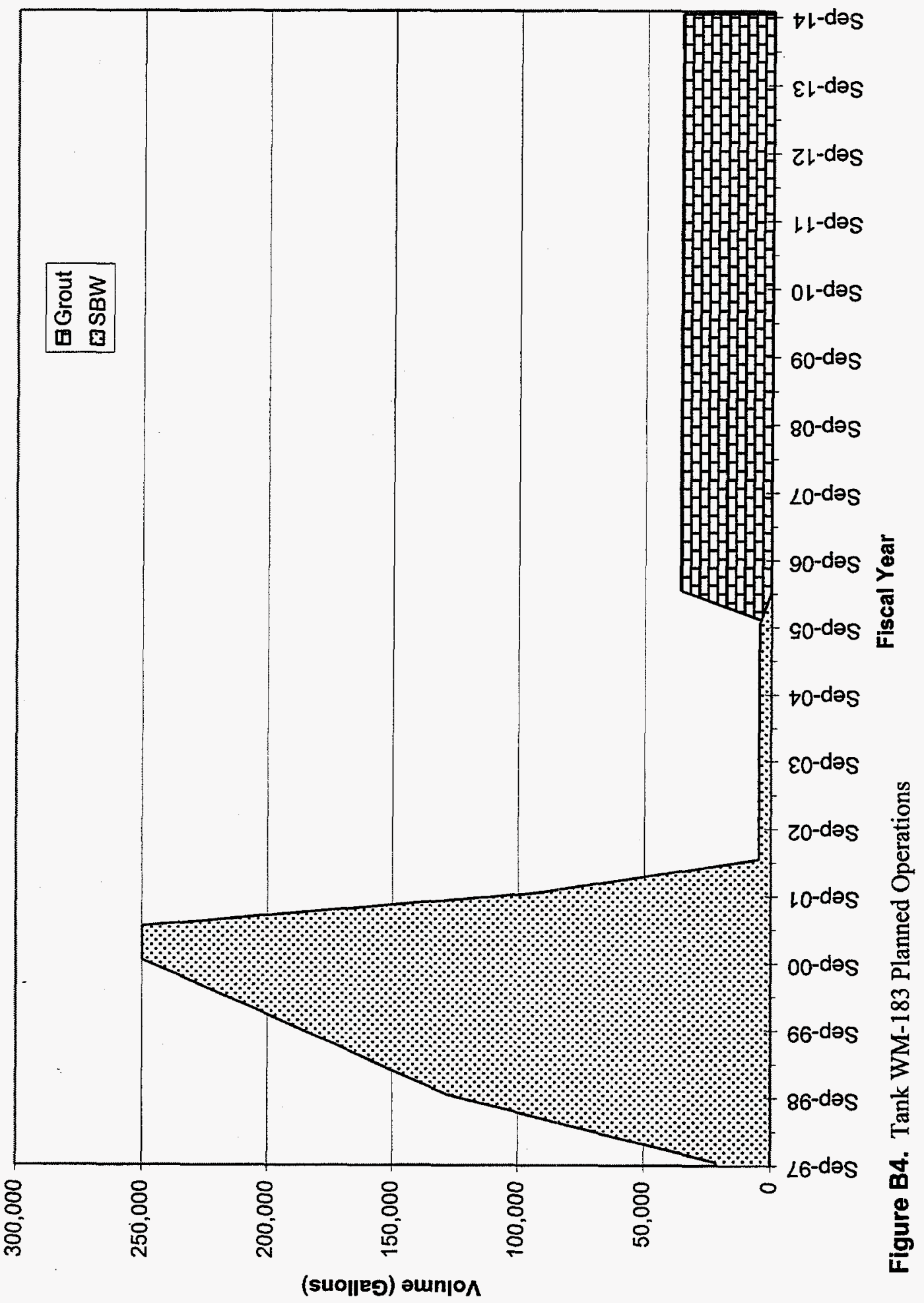




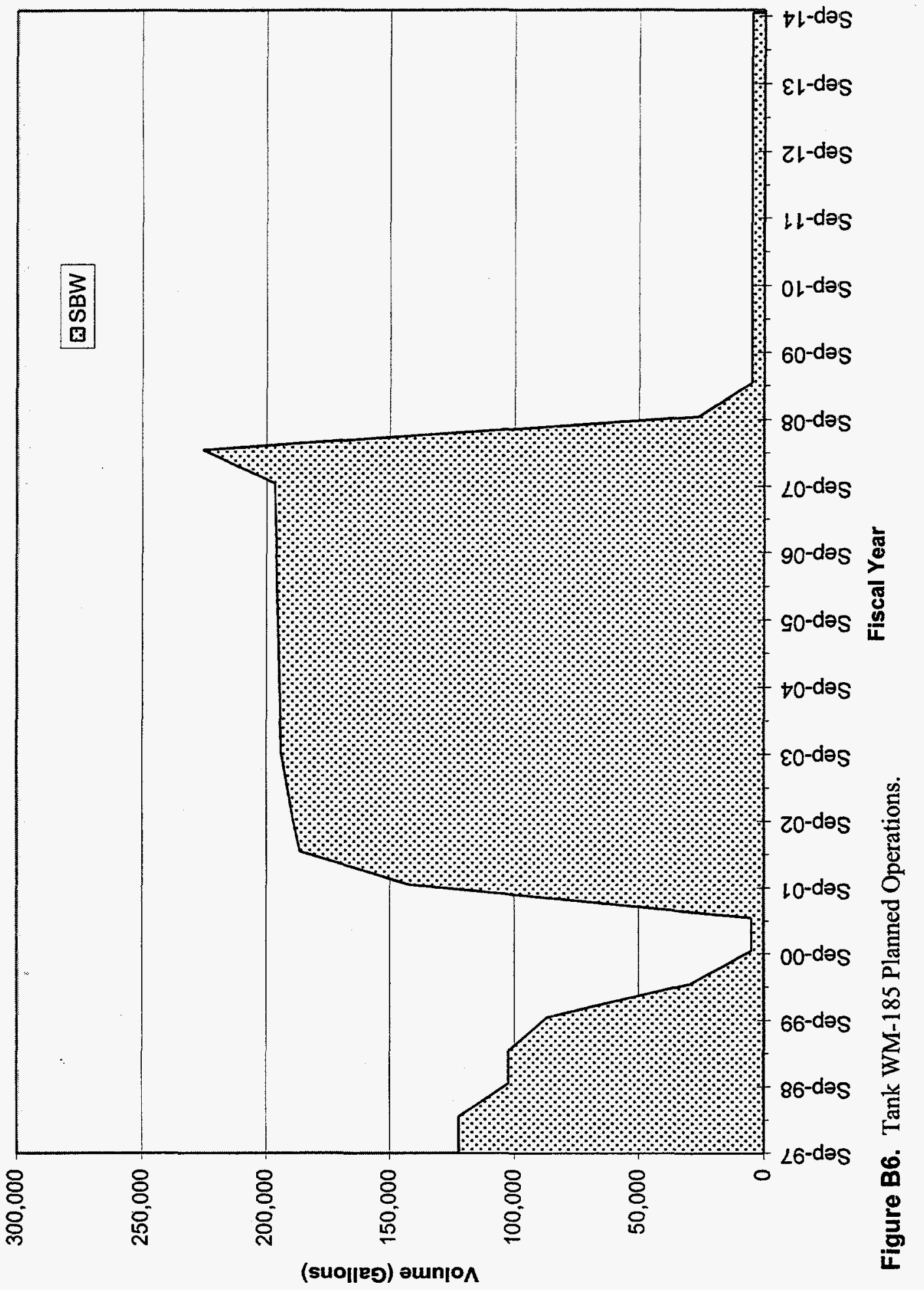




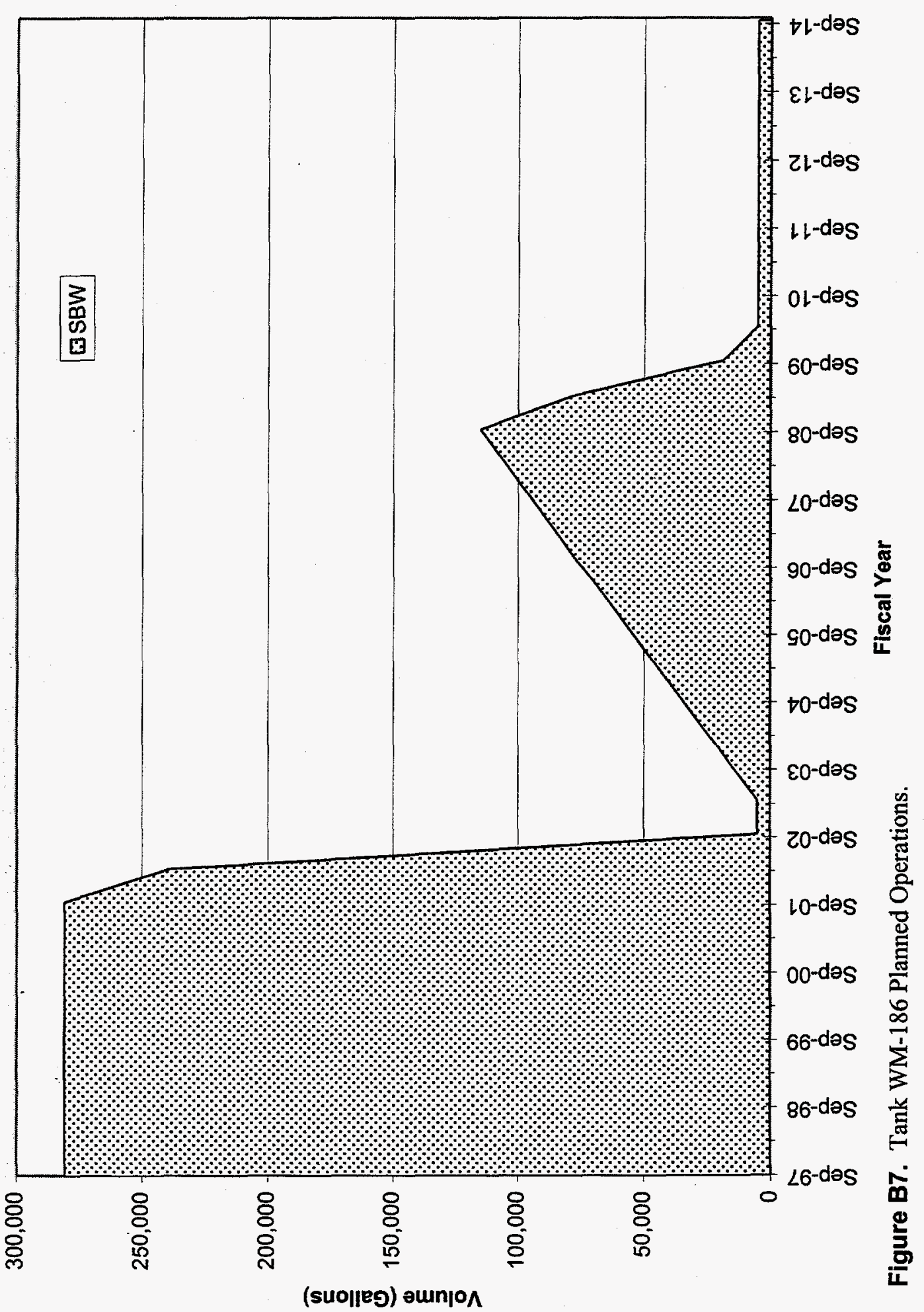

B-8 


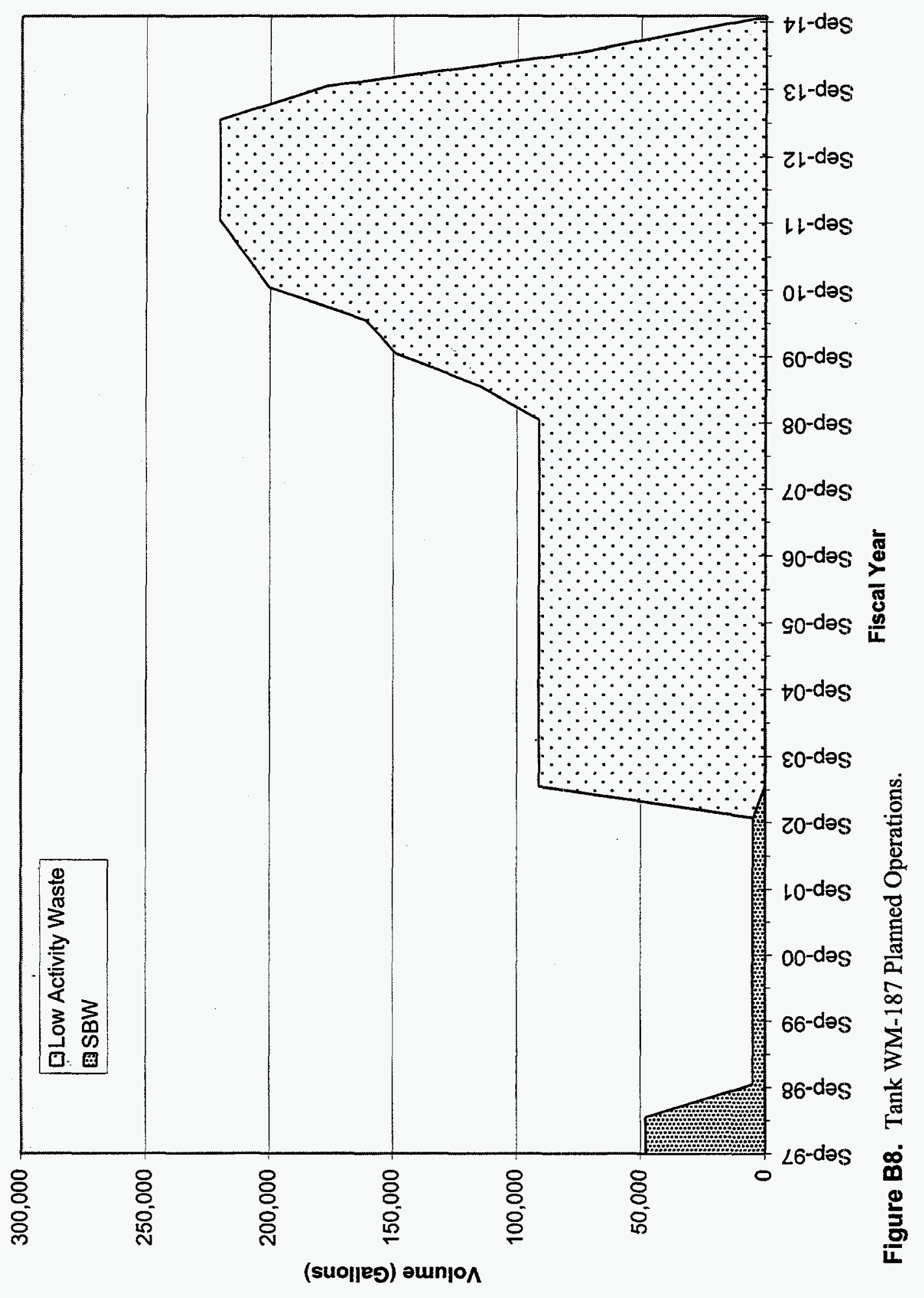




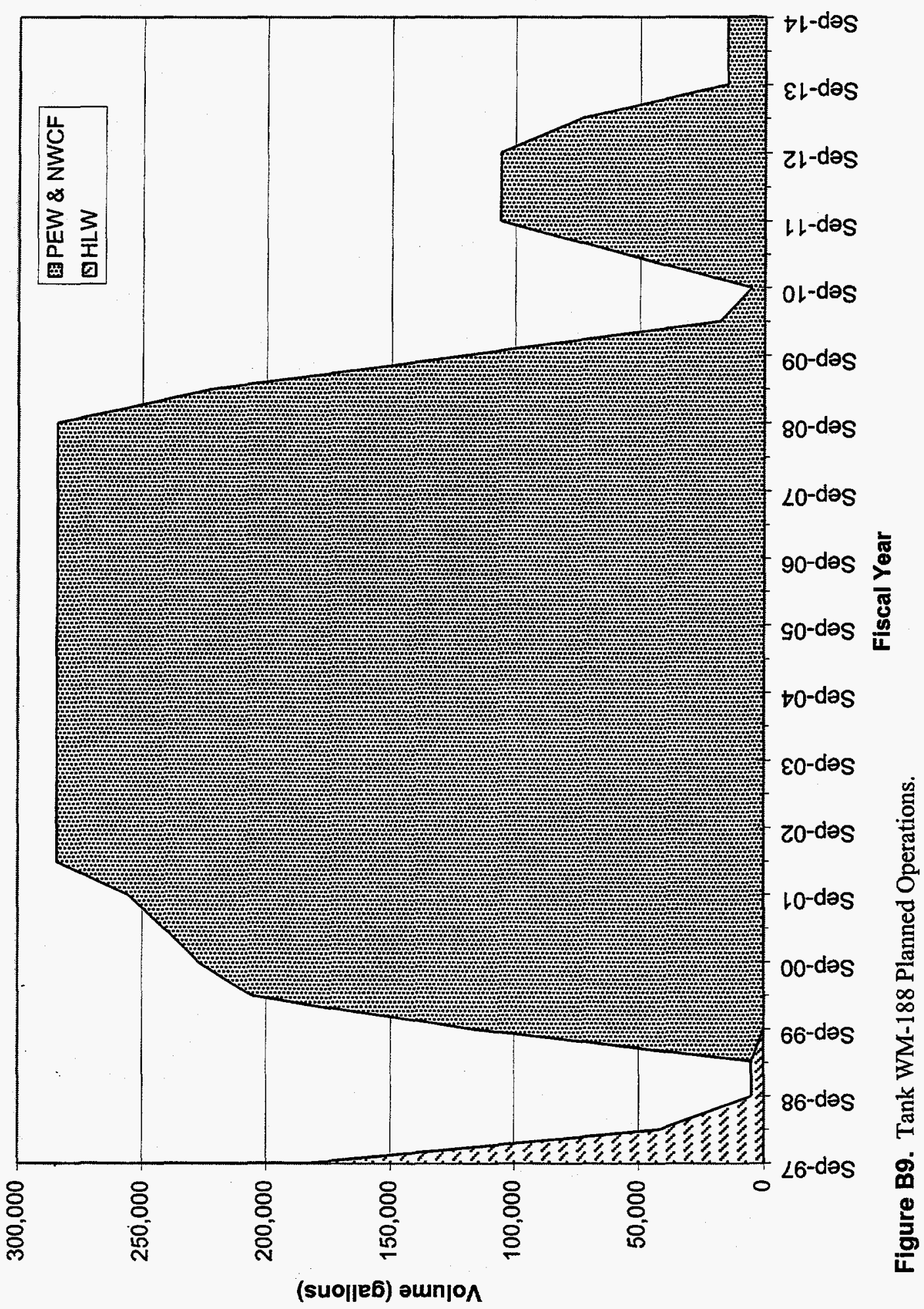

B-10 


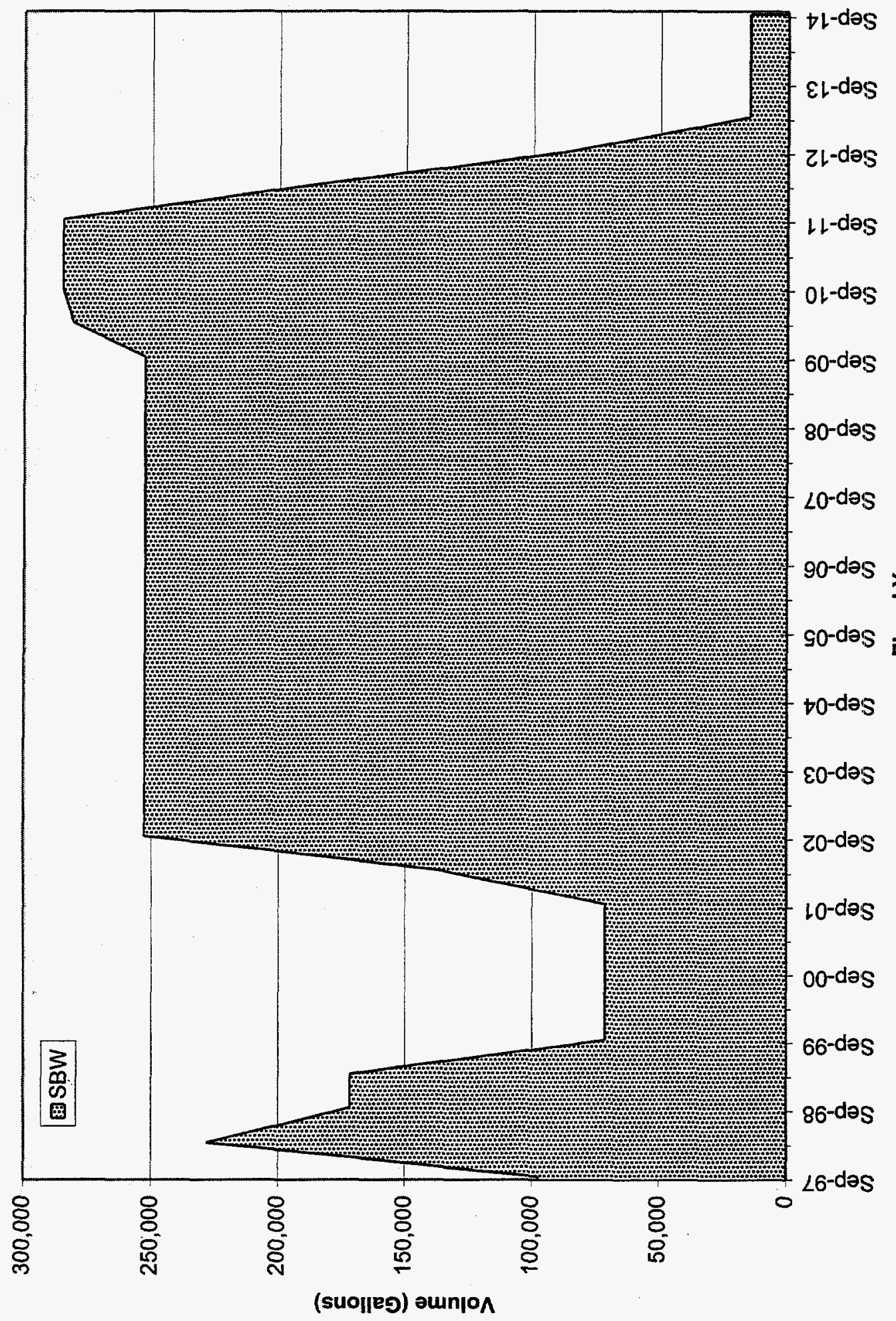

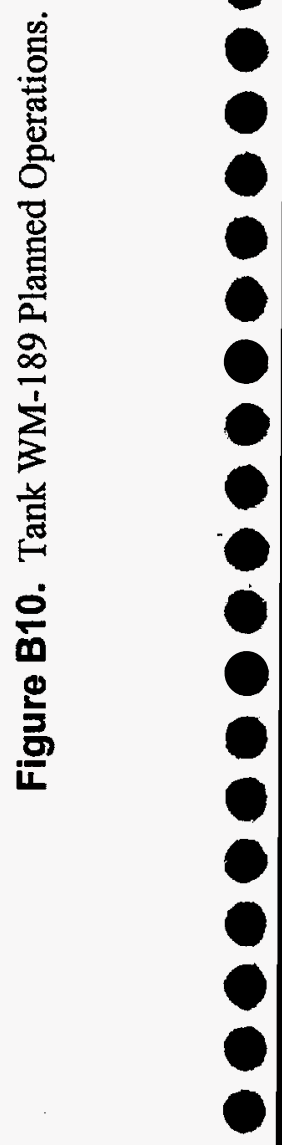




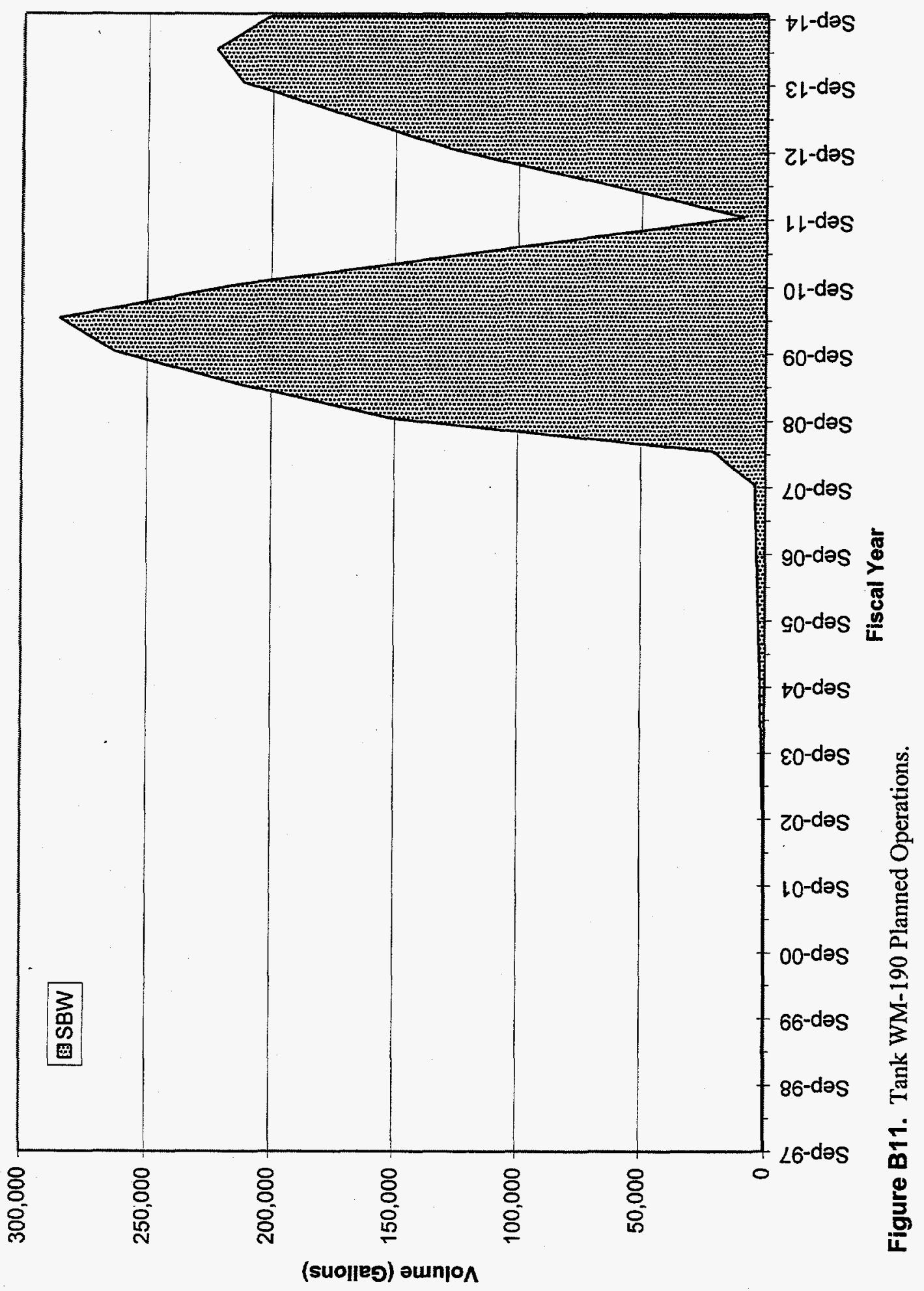

B-12 


\section{APPENDIX C}

\section{DETAILED WASTE TANK OPERATIONS FOR THE DECEMBER 1997 CASE}




\section{APPENDIX C}

\section{DETAILED WASTE TANK OPERATIONS FOR THE DECEMBER 1997 CASE}

Figure C1. Tank WM-180 Planned Operations ..............................................................

Figure C2. Tank WM-181 Planned Operations ..........................................................

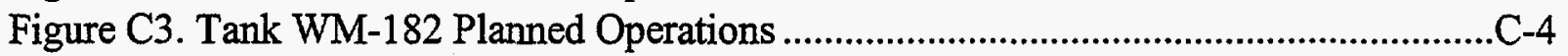

Figure C4. Tank WM-183 Planned Operations ................................................................5

Figure C5. Tank WM-184 Planned Operations ..............................................................6

Figure C6. Tank WM-185 Planned Operations ..................................................................

Figure C7. Tank WM-186 Planned Operations .................................................................

Figure C8. Tank WM-187 Planned Operations .................................................................9

Figure C9. Tank WM-188 Planned Operations ...............................................................10

Figure C10. Tank WM-189 Planned Operations ...............................................................11

Figure C11. Tank WM-190 Planned Operations .............................................................12 


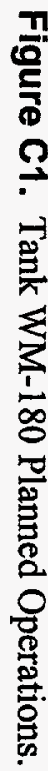

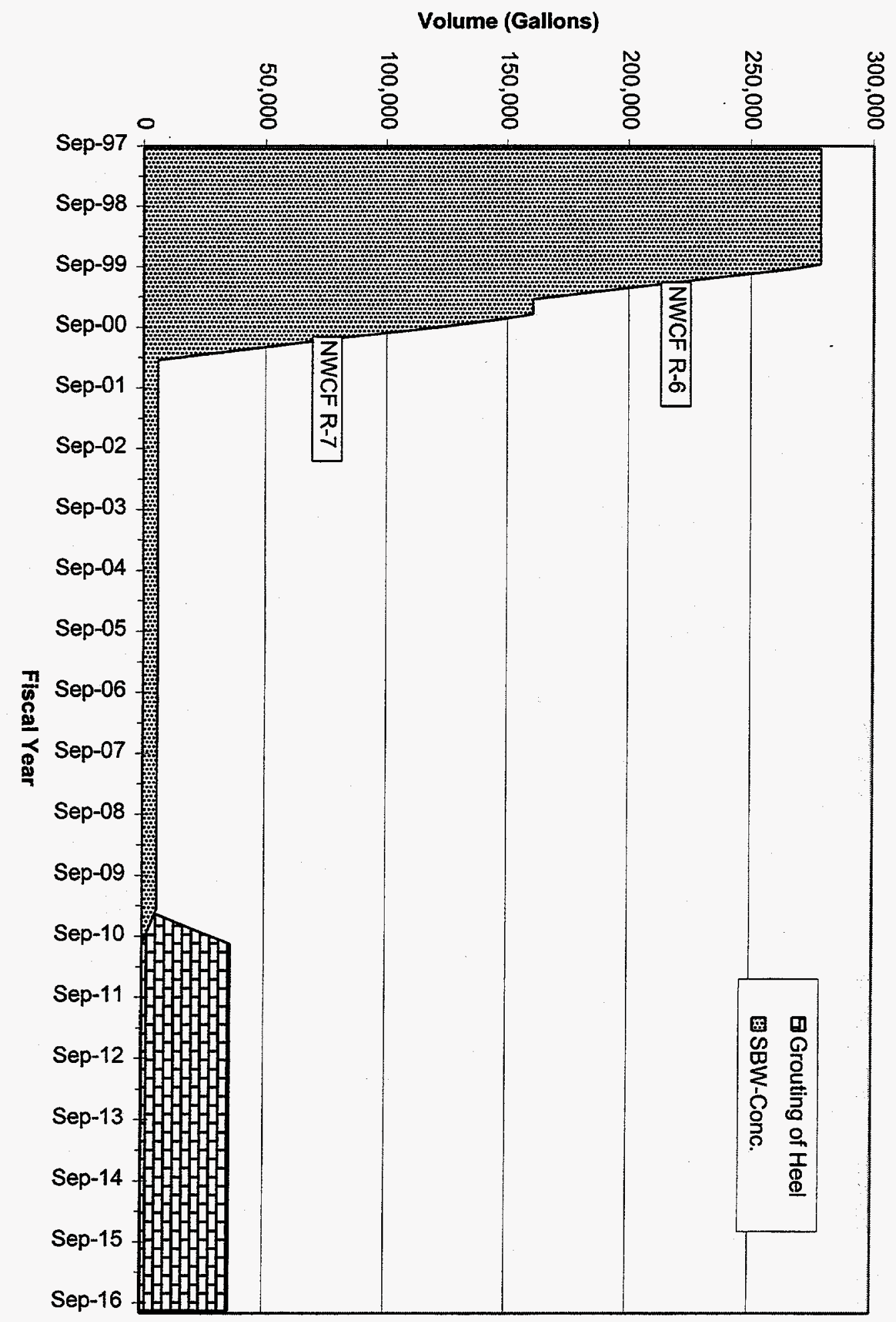




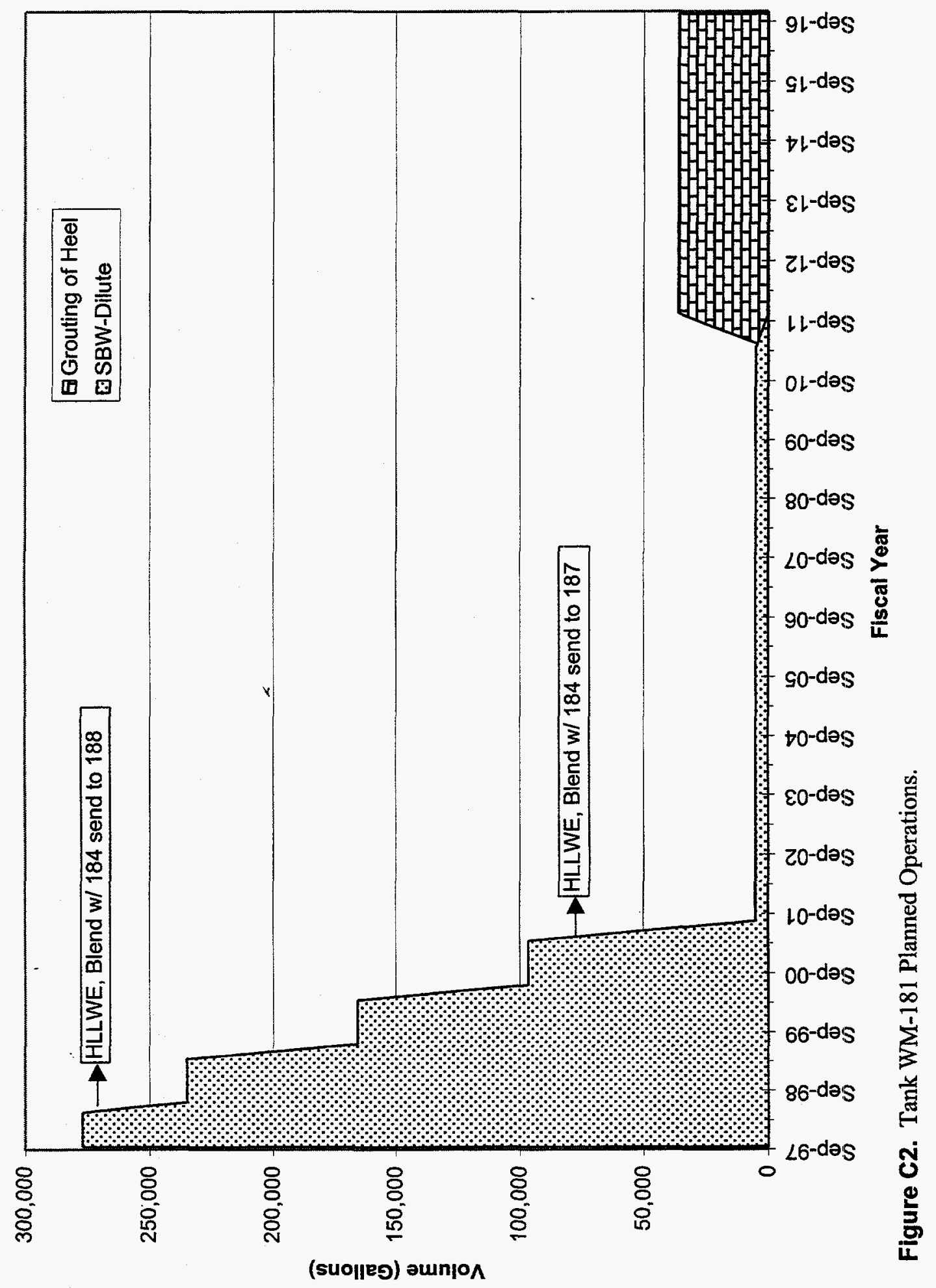




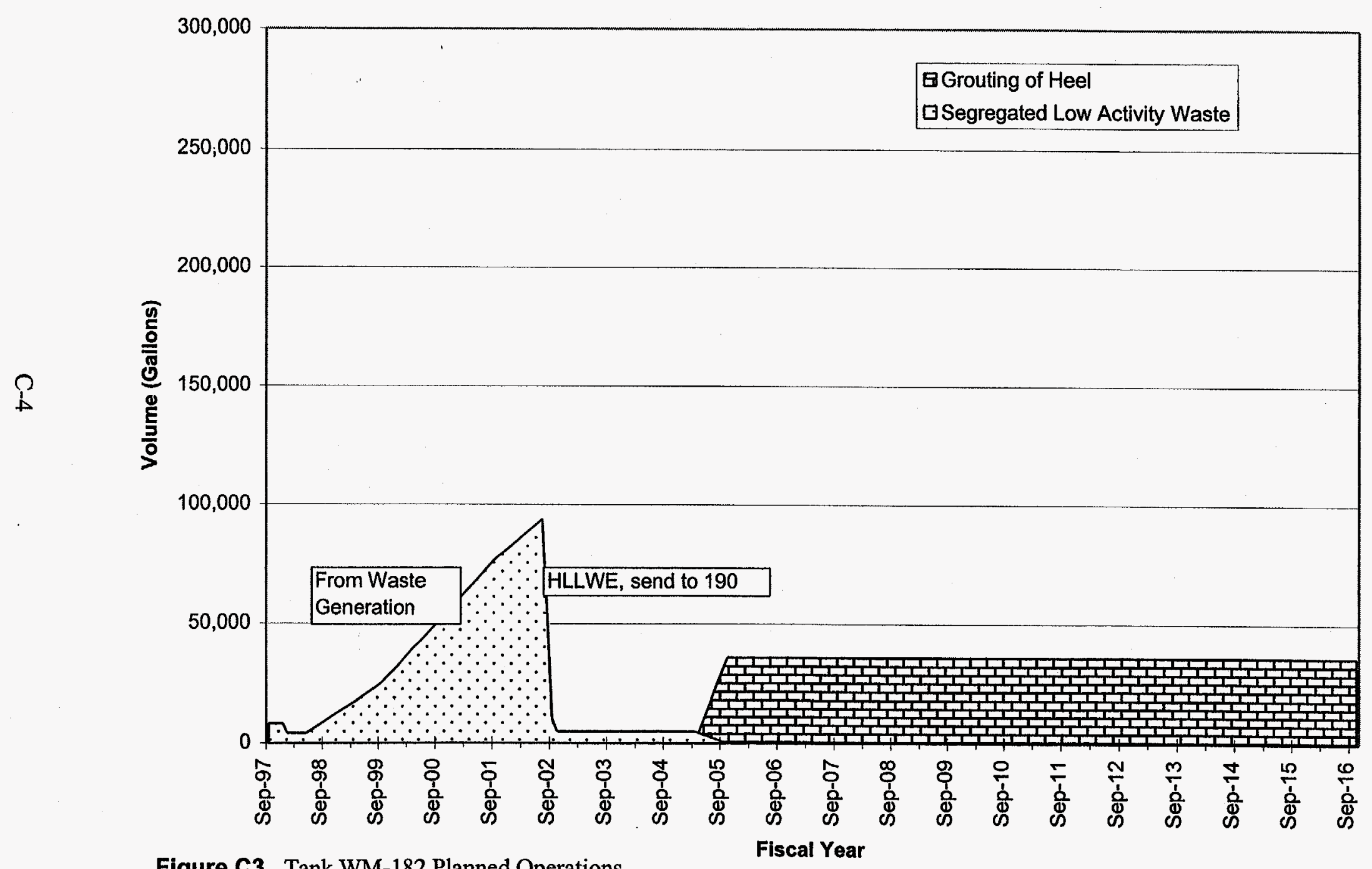

Figure C3. Tank WM-182 Planned Operations. 


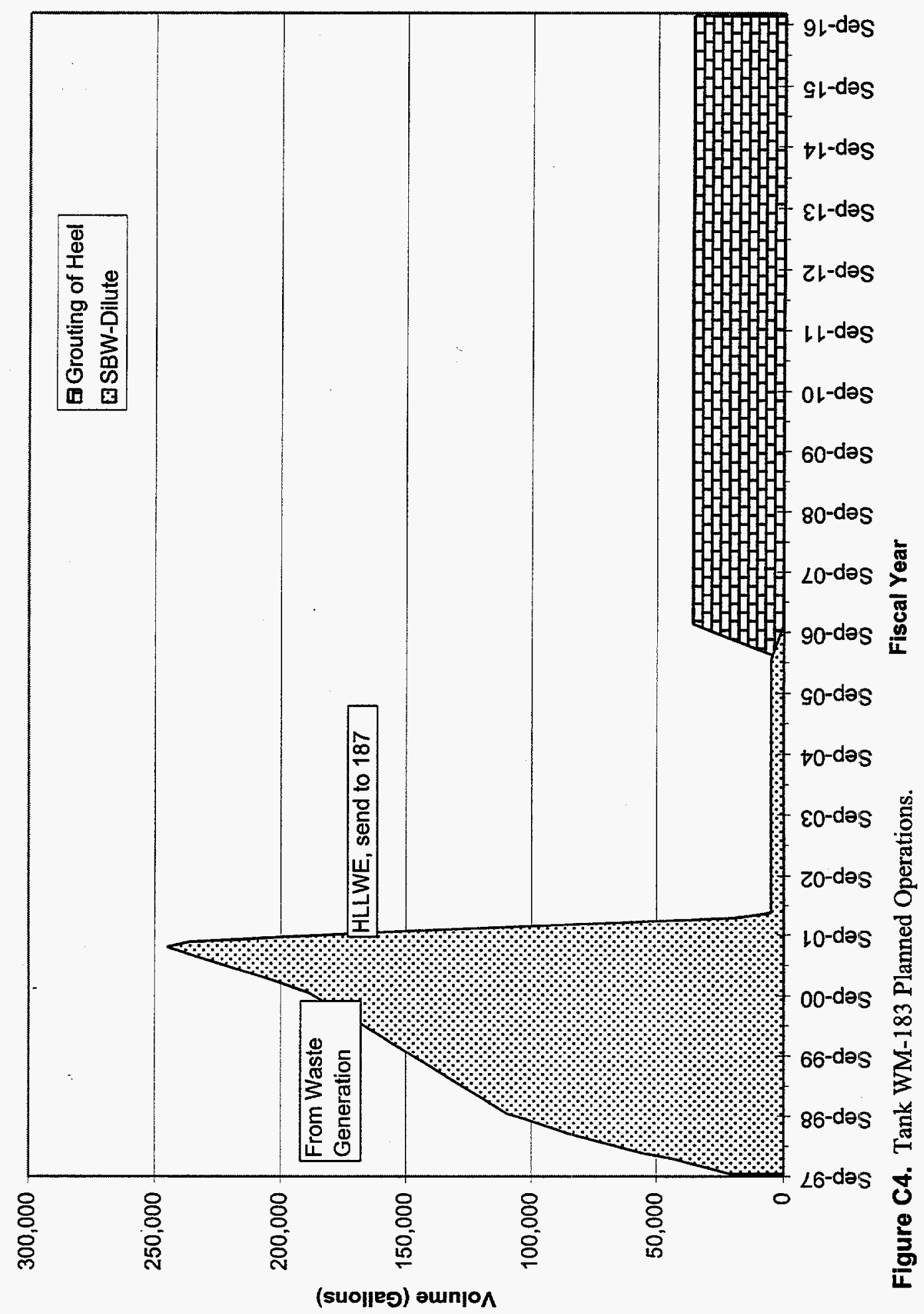




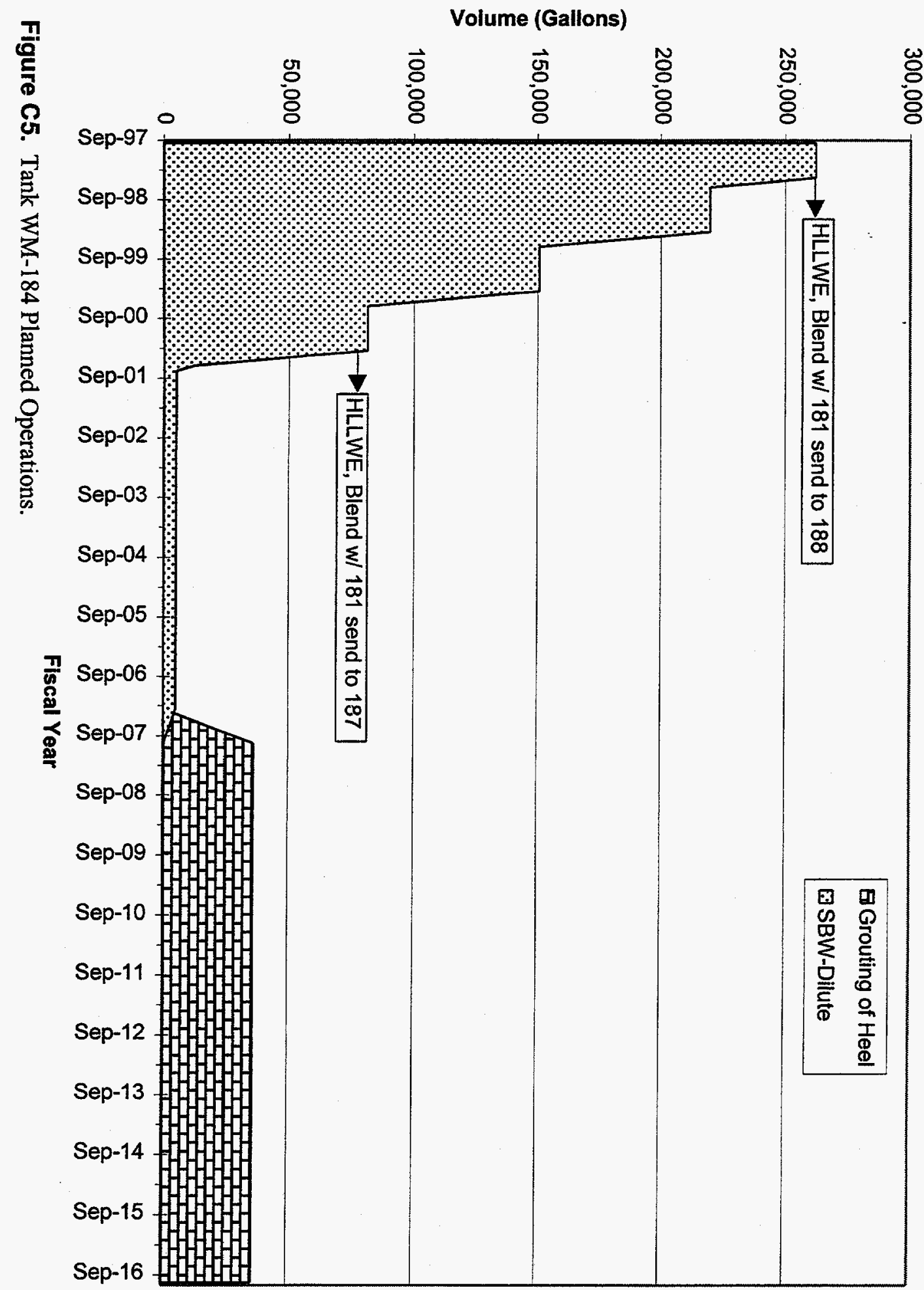




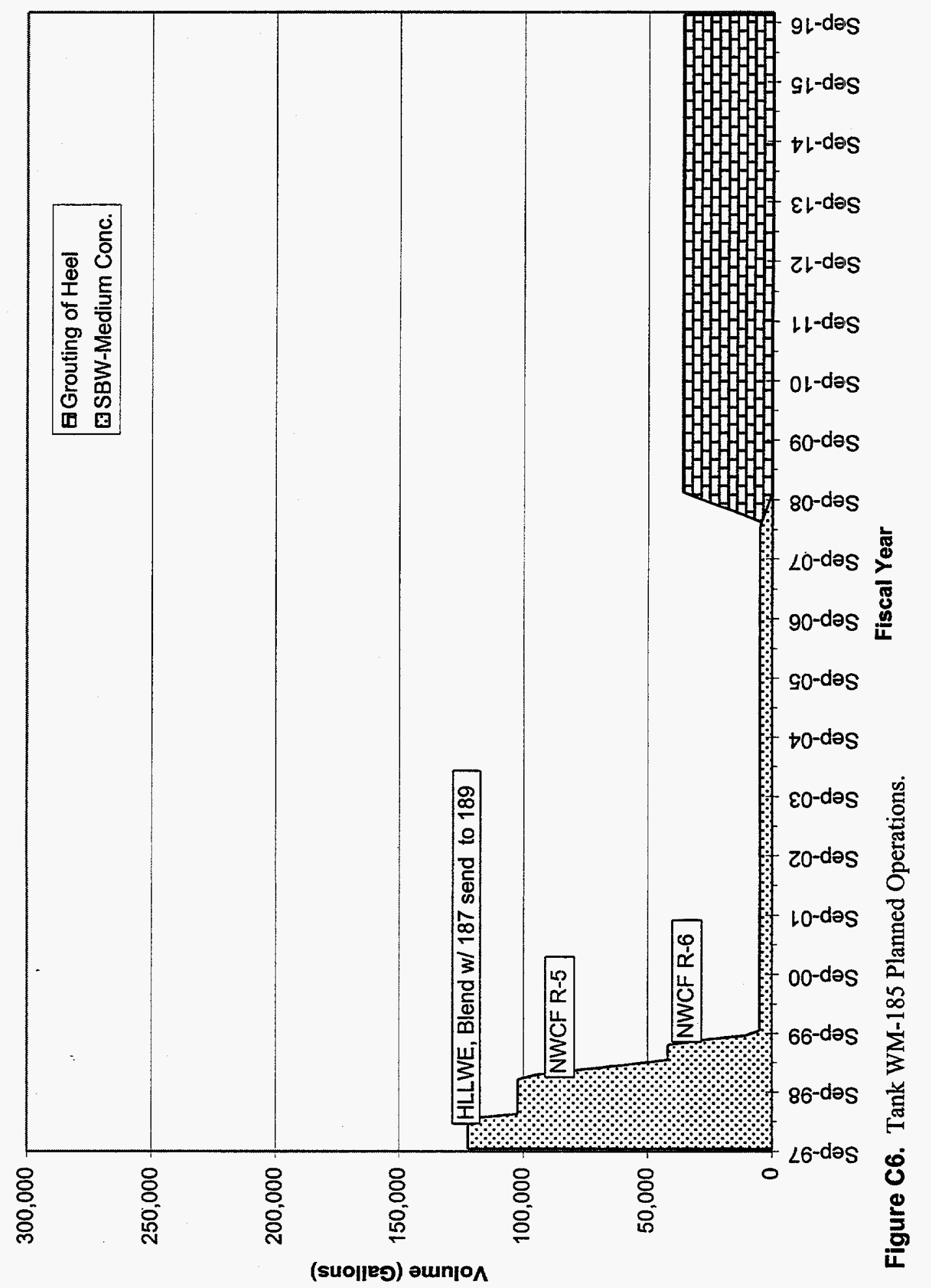




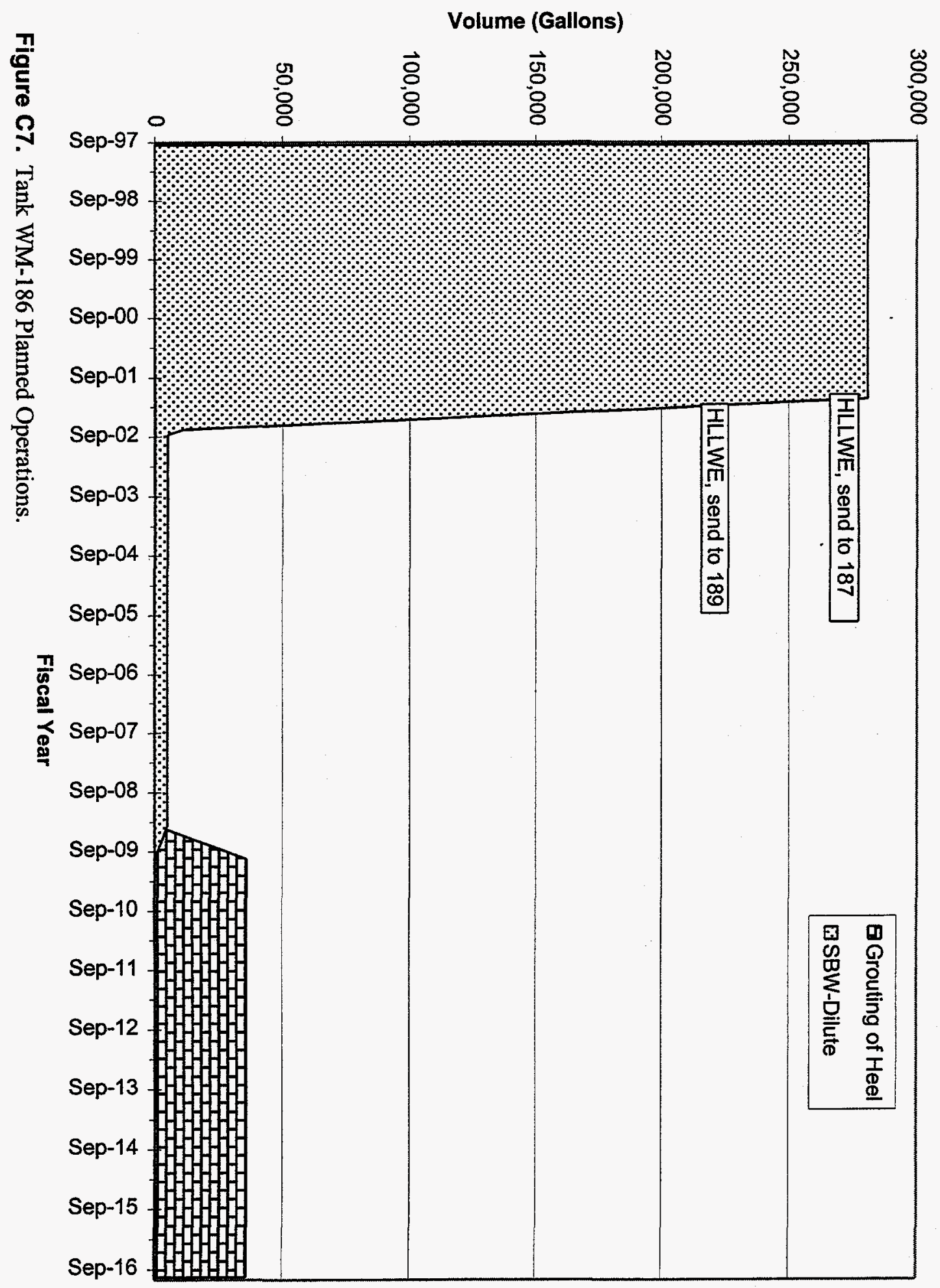




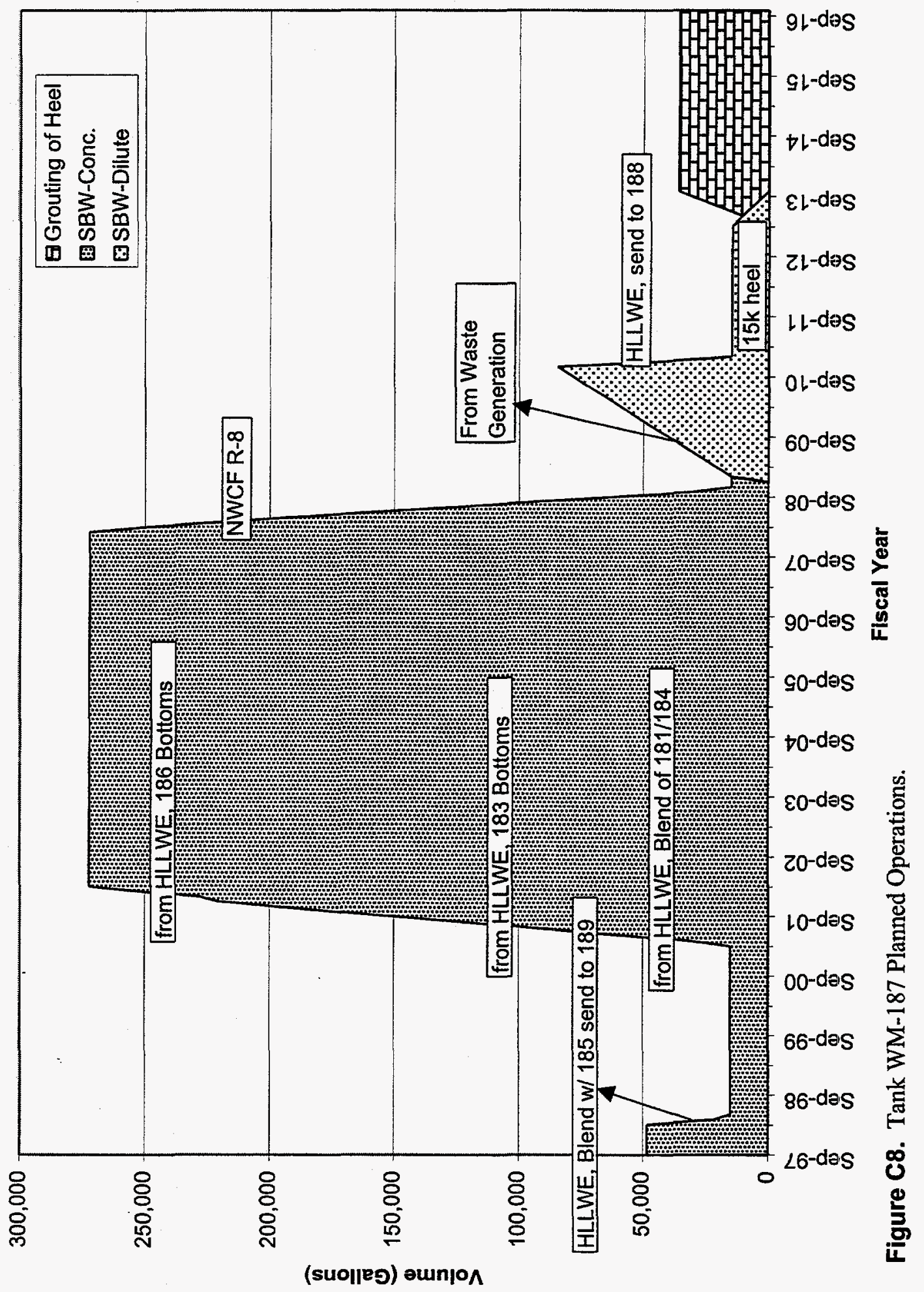




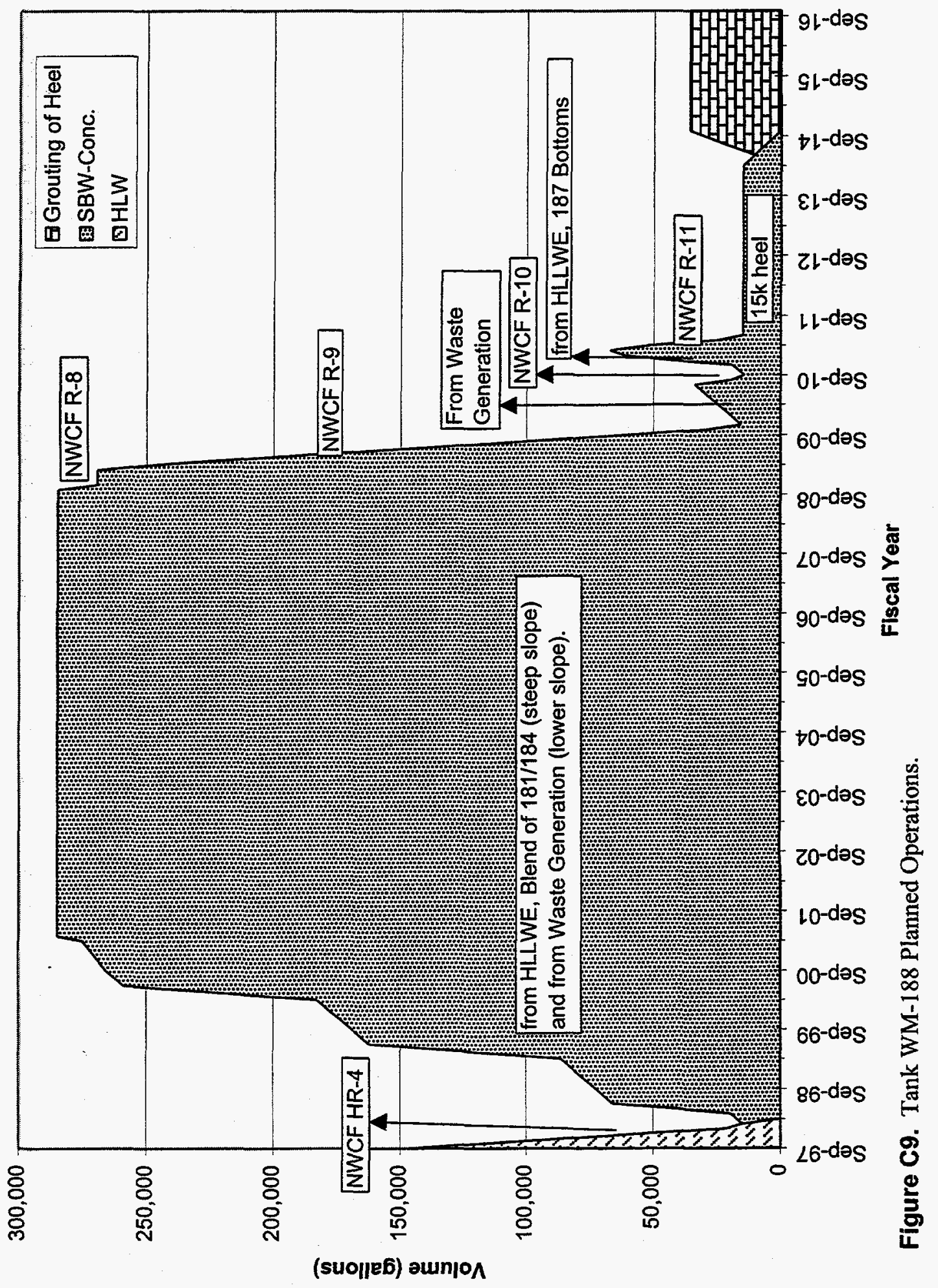

C-10 


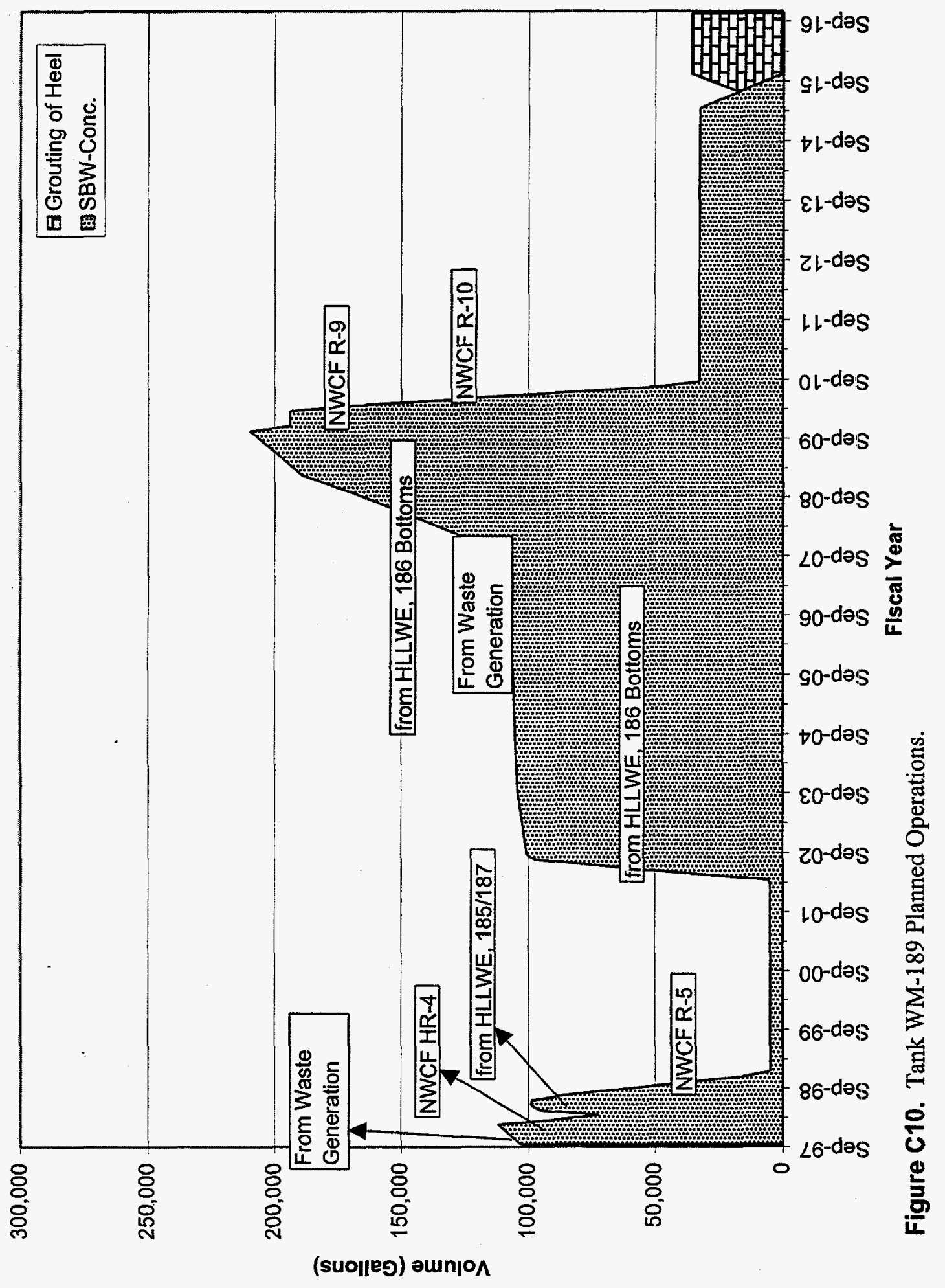




\section{ZI-O}

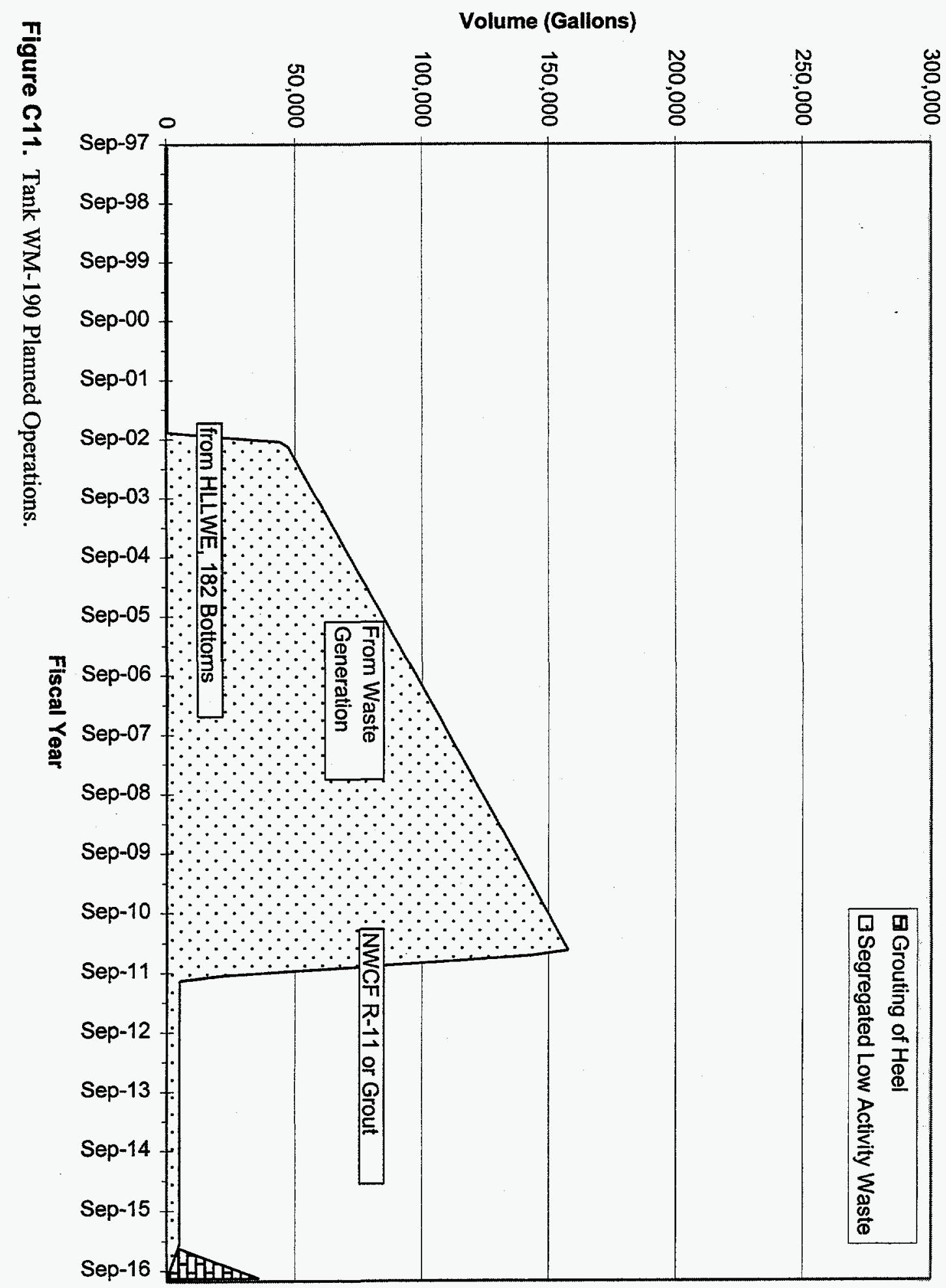

0

:

:

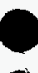

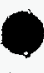

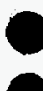

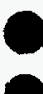

0

0

0

0

0

0

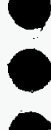

0

0

0

0

0

0

0

0

0

0

0

0

0
0
0
0
0
0
0
0
0
0
0
0 

APPENDIX D

HISTORICAL OPERATIONS OF THE TANK FARM 


\section{APPENDIX D}

\section{HISTORICAL OPERATIONS OF THE TANK FARM}

Figure D1. Historical Operations of Waste Tank WM-180 ......................................... D-2

Figure D2. Historical Operations of Waste Tank WM-181 ........................................ D-3

Figure D3. Historical Operations of Waste Tank WM-182 ........................................ D-4

Figure D4. Historical Operations of Waste Tank WM-183 ....................................... D-5

Figure D5. Historical Operations of Waste Tank WM-184 ........................................ D-6

Figure D6. Historical Operations of Waste Tank WM-185 ........................................... D-7

Figure D7. Historical Operations of Waste Tank WM-186 ........................................ D-8

Figure D8. Historical Operations of Waste Tank WM-187 ............................................ D-9

Figure D9. Historical Operations of Waste Tank WM-188 ........................................ D-10

Figure D10. Historical Operations of Waste Tank WM-189 …................................. D-11

Figure D11. Historical Operations of Waste Tank WM-190 ...................................... D-12 


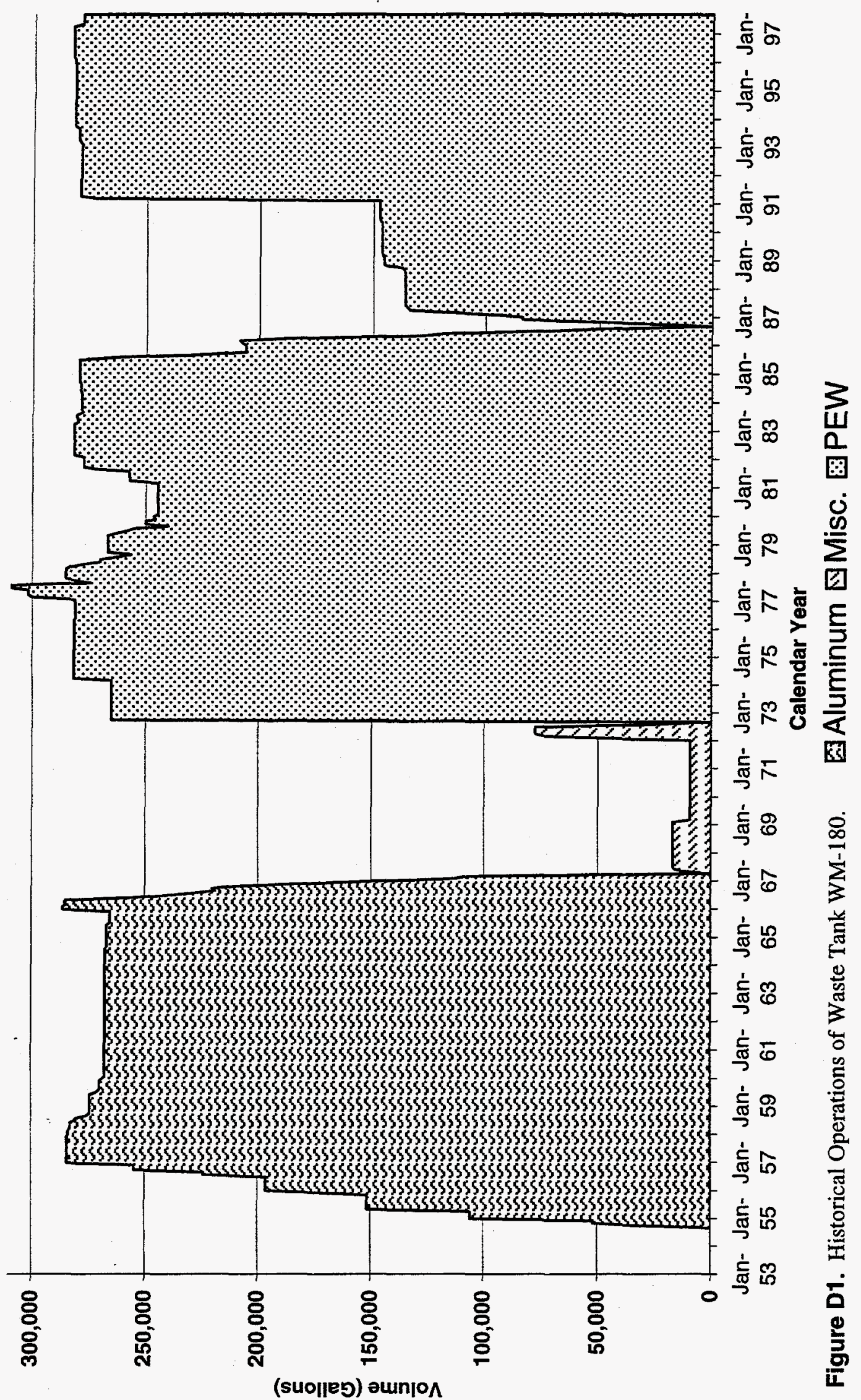




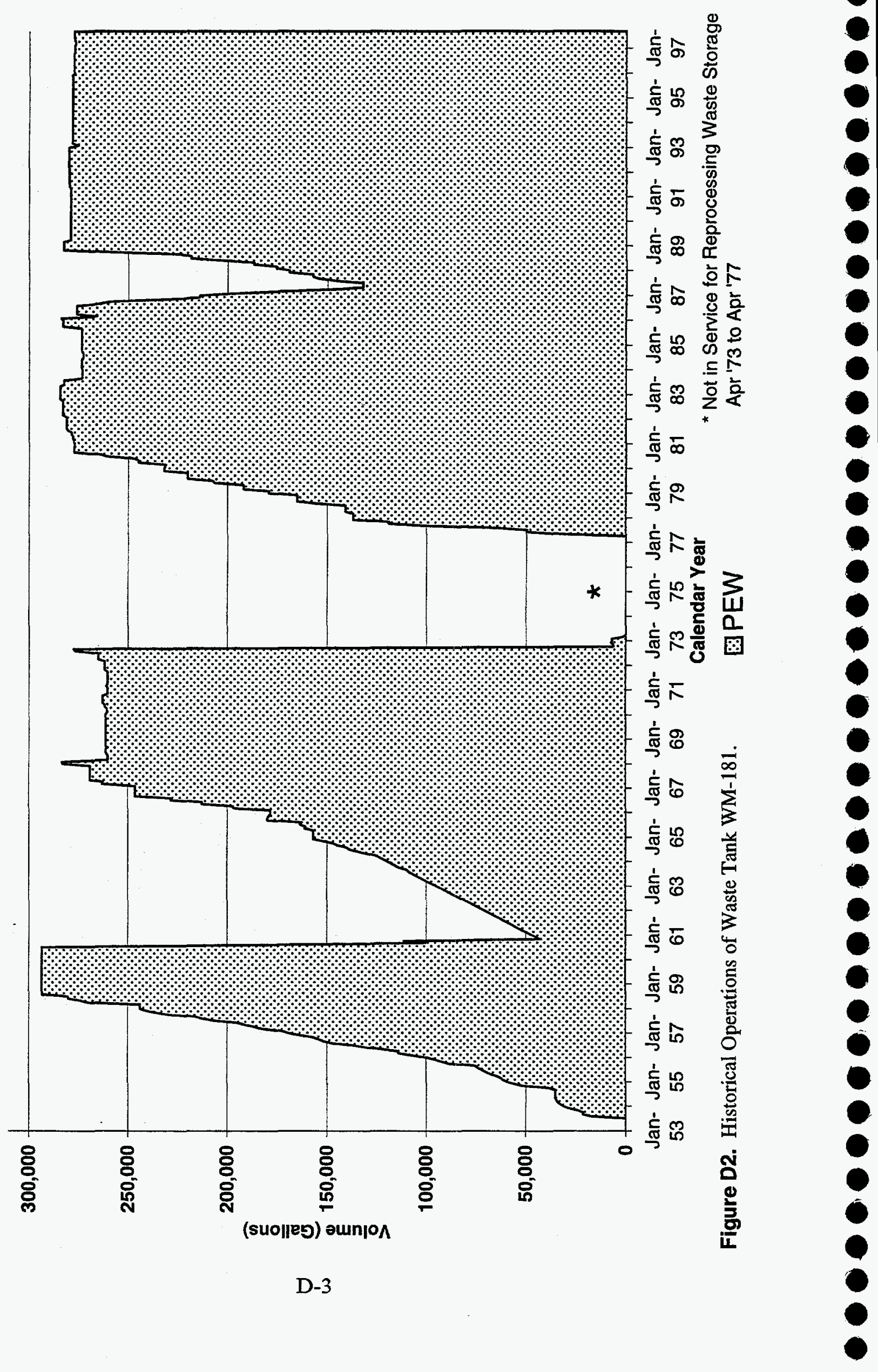




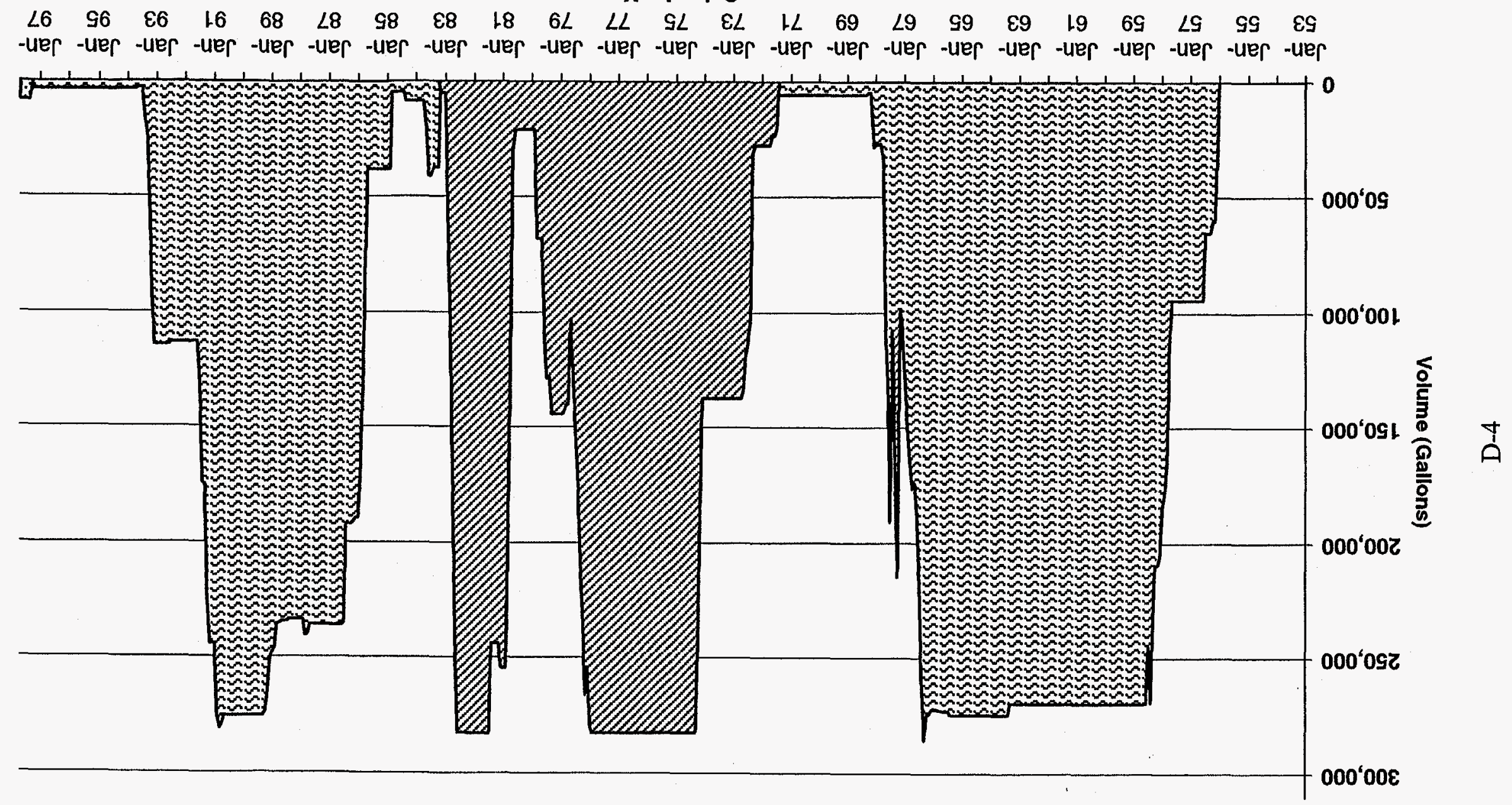




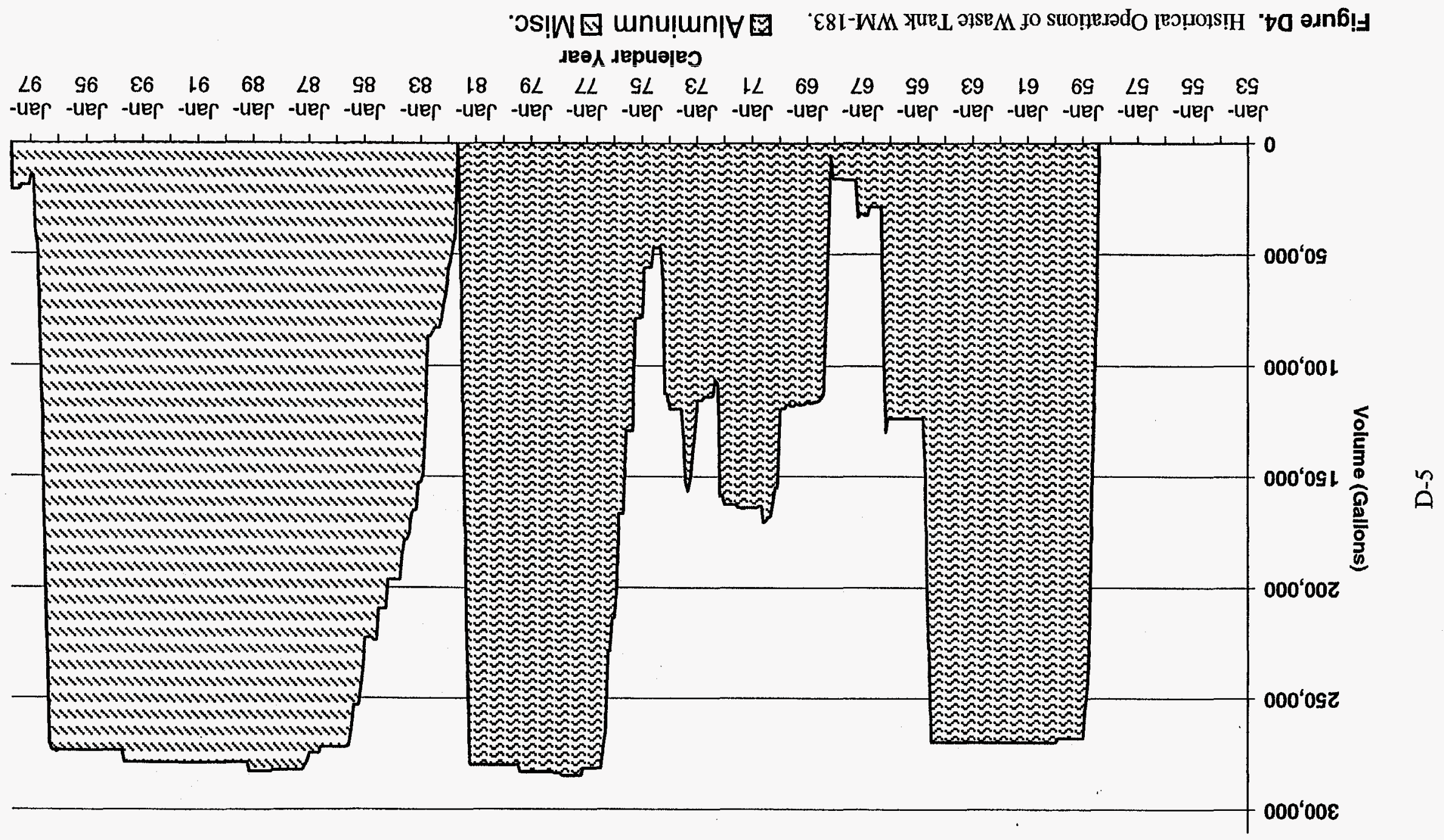




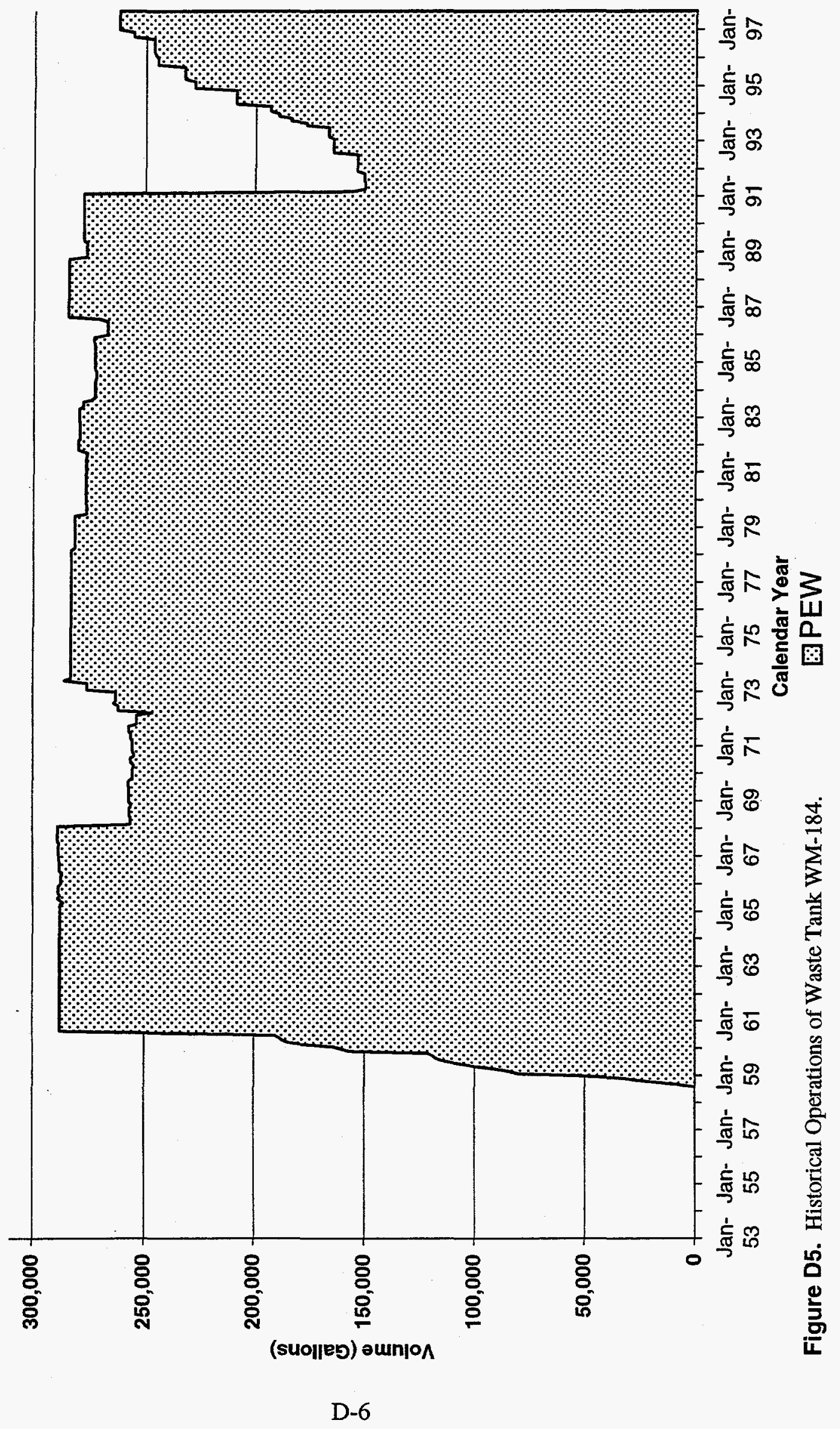




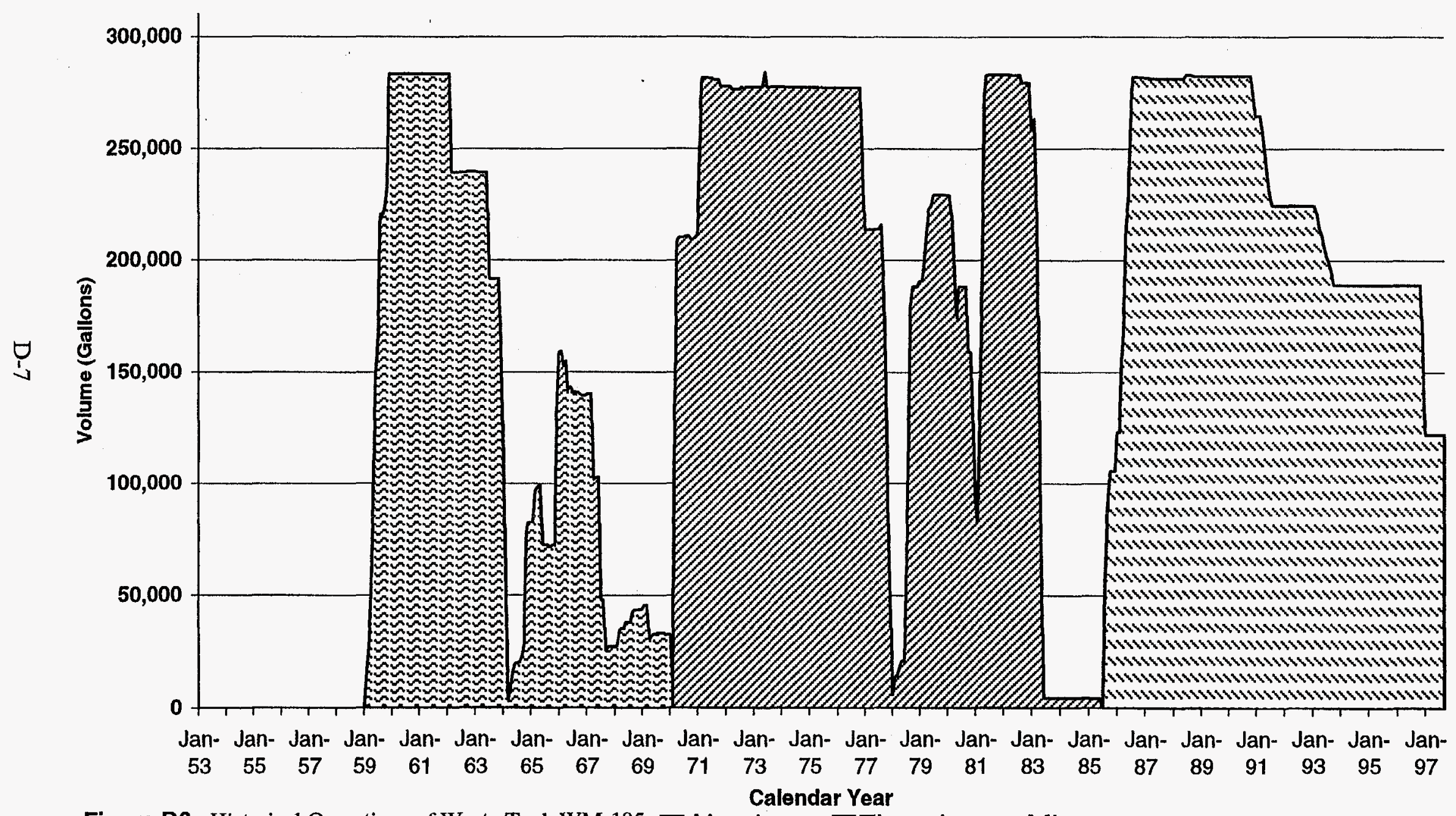

Figure D6. Historical Operations of Waste Tank WM-185. 图Aluminum ØZirconium @Misc. 


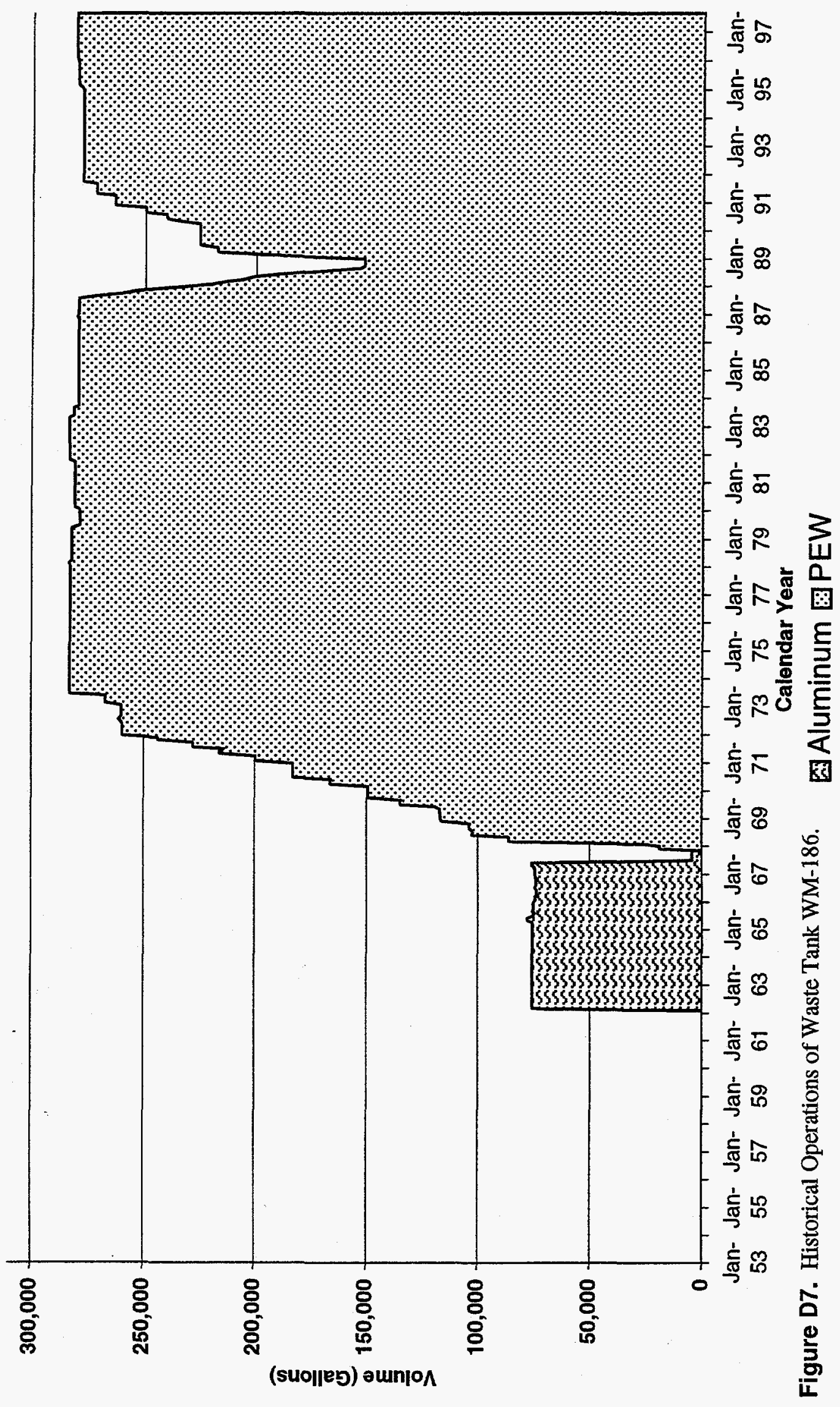

D-8 


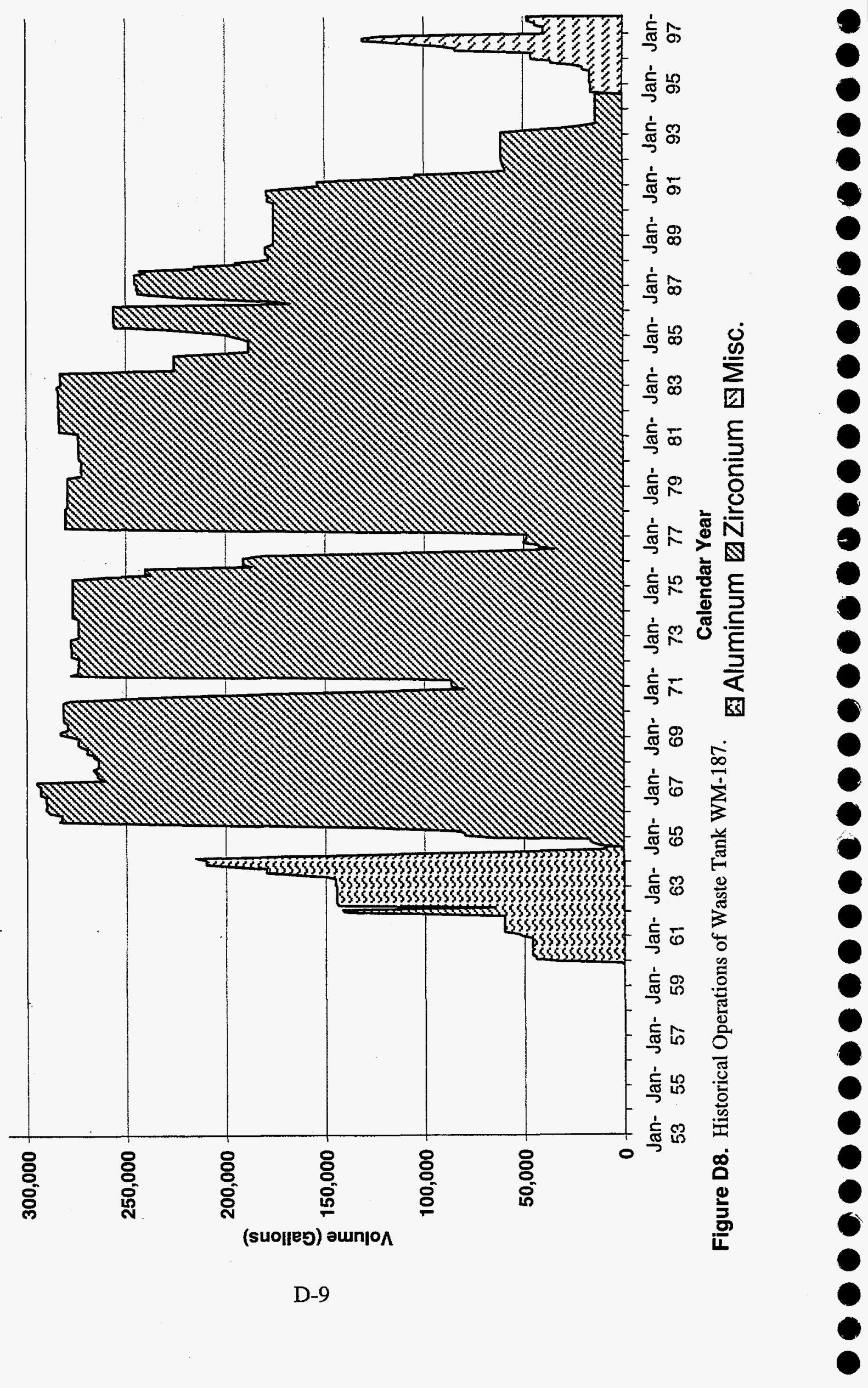




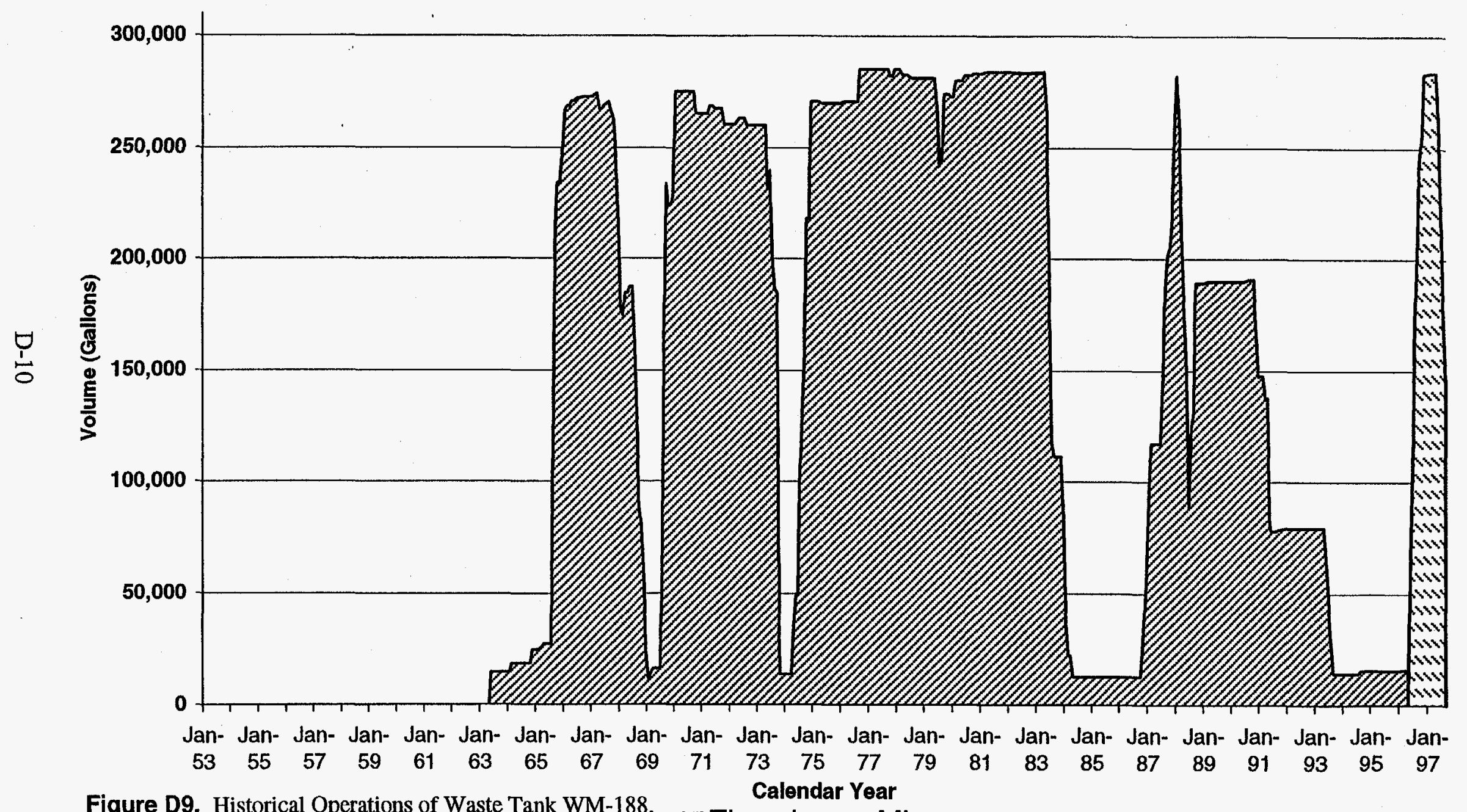

Figure D9. Historical Operations of Waste Tank WM-188. $\checkmark$ Zirconium $₫$ Misc. 


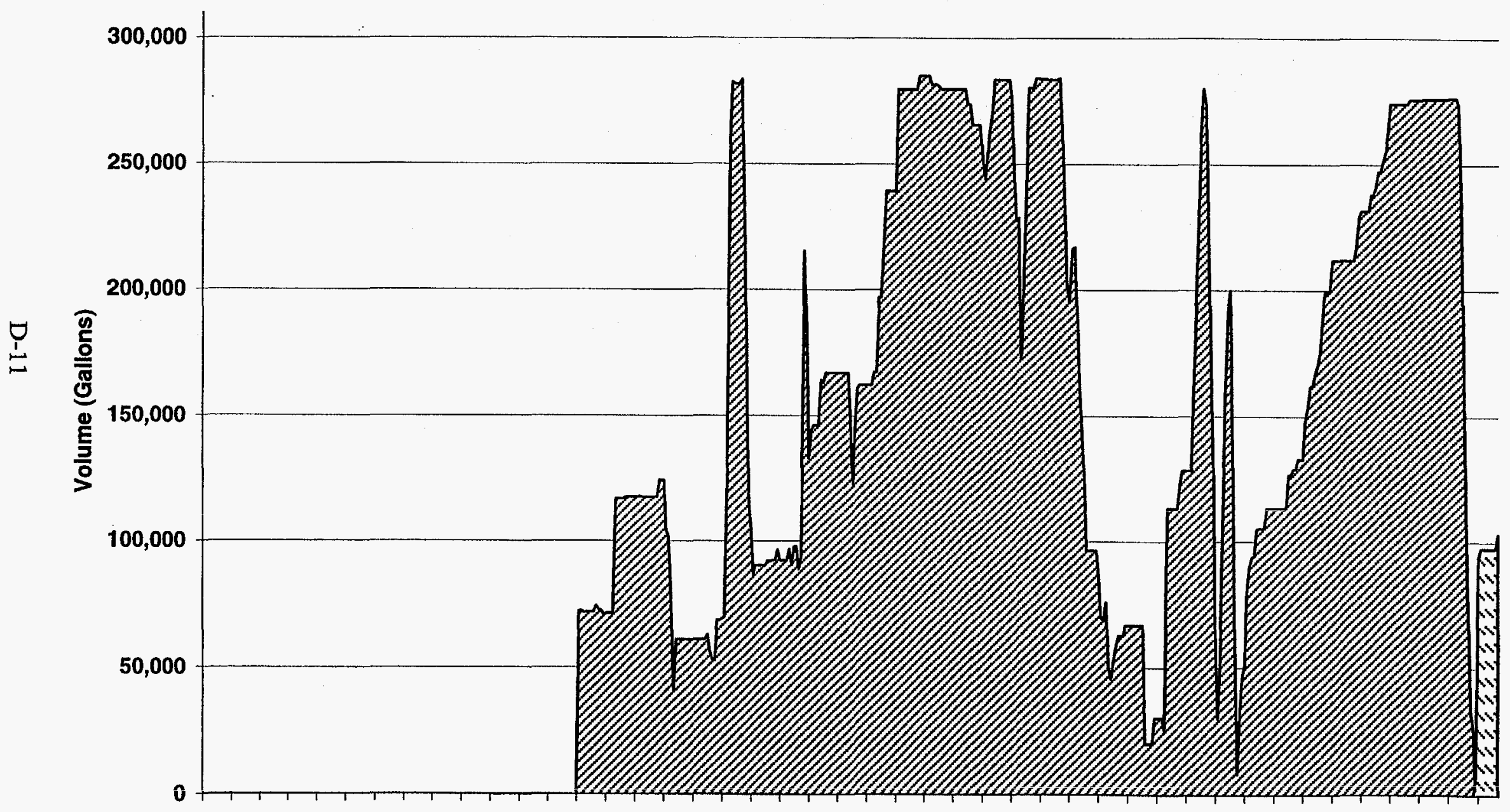

Jan- Jan- Jan- Jan- Jan- Jan- Jan- Jan- Jan- Jan- Jan- Jan- Jan- Jan- Jan- Jan- Jan- Jan- Jan- Jan- Jan- Jan- Jan$\begin{array}{lllllllllllllllllllllll}53 & 55 & 57 & 59 & 61 & 63 & 65 & 67 & 69 & 71 & 73 & 75 & 77 & 79 & 81 & 83 & 85 & 87 & 89 & 91 & 93 & 95 & 97\end{array}$

Figure D10. Historical Operations of Waste Tank WM-189. Z Zirconium $\otimes$ Misc. 


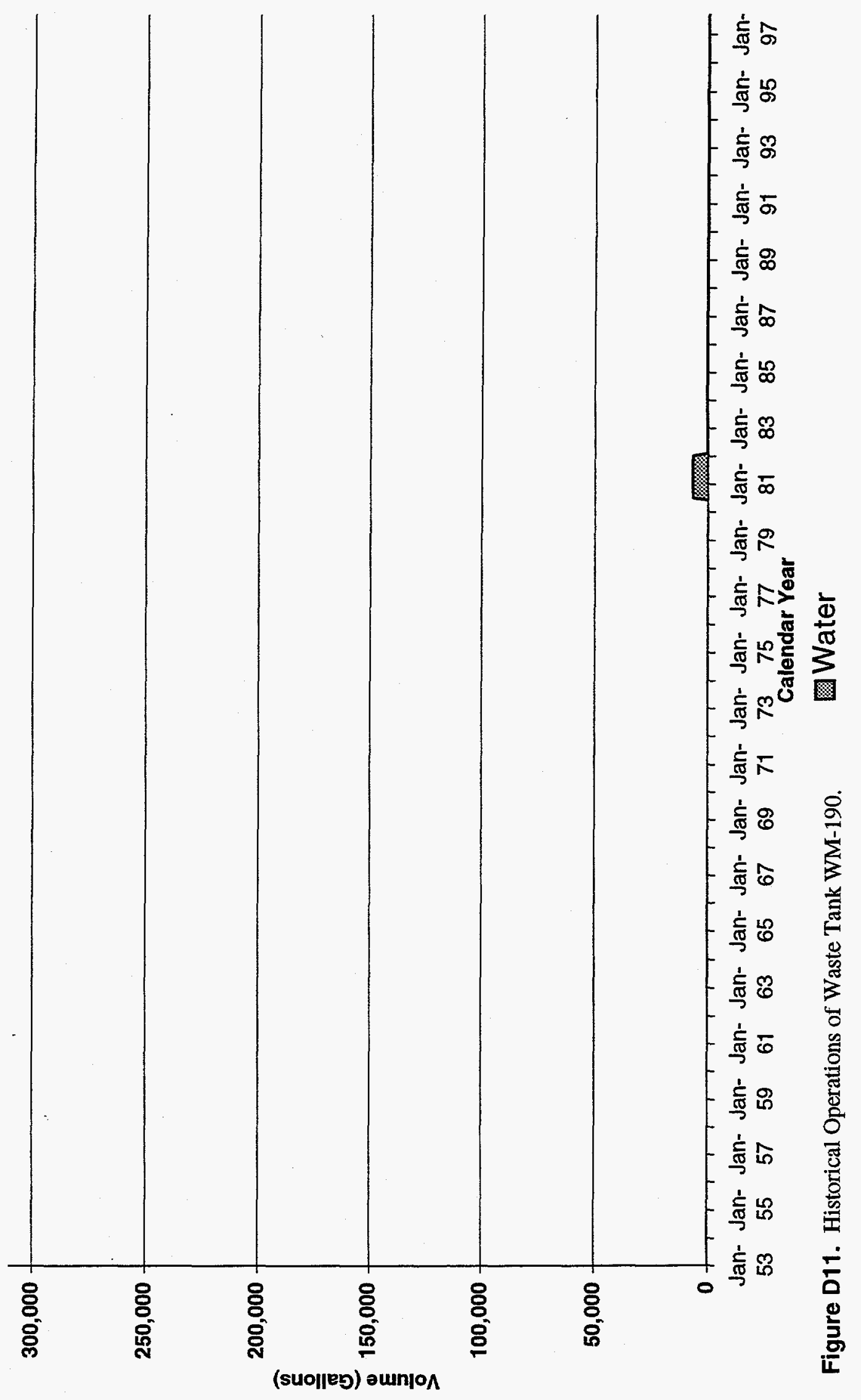

D-12 


\section{APPENDIX E}

\section{WASTE SEGREGATION PLAN}


Date: $\quad$ November 18,1997

To:

R. R. Chase

MS 5108

$6-0018$

From:

F.S. Ward stwand

MS 5111

$6-3010$

Subject: $\quad$ PEWE WASTE SEGREGATION PLAN - FSW-17-97

Reference: Report INEEL/EXT-97-00988, J. L. Tripp, Idaho Chemical Processing Plant Waste Minimization Plan, published August 1997.

Attached is the Waste Segregation Plan for the waste feed into the PEWE system as required by the Reference. It has been reviewed by Environmental, Programs, Operations, and Engineering. The HIL Programs office is using it for the tank farm projections and wants to make it available on their home page. There are still several items that must be completed prior to actually using the WL-111 bottoms tank for this waste segregation.

The main issues needing completion are:

1. Permit changes to allow the use of both WL-101 and WL-111.

2. Safety document changes to allow the use of WL-111.

3. Procedures to allow the use of WL-111.

4. Completion of the testing required to complete the project that installed WL-111.

5. Emptying the sodium waste from WM-182.

These issues can be completed, with the proper priority, within the next year. However, the WM-100, -101 , and -102 tanks are already being used to store 51,000 gallons of Type 2 waste for feed to the PEWE when the WL-111 tank becomes available.

This letter is the official transmittal so the plan can be used. If you have any questions, please contact me at 526-3010.

mea

Attachment

cc: $\quad$ D. S. Chinich, MS 5111

W. B. Palmer, MS 3211

M. M. Garland, MS 5117

J. L. Tripp, MS 5218

M. B. Heiser, MS 3211

F. S. Ward letter file

J. E. Hovinga, MS 5108

J. M. White, MS $511 \mathrm{lg}$ ht

C. B. Millet, MS 3211

UFC 7452 


\title{
Tank Farm and PEWE Waste Segregation Plan for Type 1 and Type 2 Waste
}

\author{
Revision 0 \\ October 30, 1997 \\ Printed November 18, 1997
}

\section{Introduction}

References 1 \& 2 categorize the liquid wastes being generated as Type 1 or Type 2 depending on the source and the required follow on treatment in preparation of the Waste Minimization Incentive being approved. Most of these waste solutions will be processed in the Process Equipment Waste Evaporator (PEWE) system. Reference 3 is the first of 4 quarterly reports that status the ongoing waste generation and assesses the progress towards meeting the goals during FY-97.

Because these wastes are presently being generated and will continue to be generated, the following plan has been developed to start the waste segregation as soon as possible. It provides the optimum waste segregation, which will enhance waste minimization efforts and allow flexibility to maximize waste processing to empty the tank farm in accordance with the consent orders. It will also provide several additional years accumulation of feed for the grout facility when it starts up that would otherwise have to be either calcined or separated if it was blended with the Type 1 waste as is presently done. This segregation will not impact or limit any waste treatment options, the High Level Liquid Waste Evaporator (HILWE) and the New Waste: Calcining Facility (NWCF) could continue to be used, the new planned waste treatment facilities could be used, or different plans could be developed for the future waste treatment.

This plan outlines a method of collecting and segregating the two waste Types as they are generated, processed, and stored as required on page 3 of reference 2 . Figure 1 is a schematic diagram, which depicts these waste systems to help visualize the flow path described in this plan.

The Type 1 wastes are low activity liquid wastes that are generated during treatment of wastes associated with the past fuel reprocessing operations. These wastes will require calcination or separation for treatment to empty these wastes from the tank farm (e.g. HILWE concentration of the sodium bearing waste now stored in the tank farm and wastes returned to the tank farm from NWCF operations).

The Type 2 wastes are low activity liquid wastes that are generated by operations that are not associated with the treatment of wastes associated with the past fuel reprocessing operations. 
At̀tachment

November 18,1997

FSW-17-97

Page 2 of 6

These wastes do not require calcination or separation and could be grouted directly (e.g. liquid wastes from the fuel storage basin water treatment and wastes from other INEEL facilities).

\section{Plan Summary}

Following this plan, Type 2 wastes will be collected in tanks WM-100, WM-101, and WM-102 and later transferred into the PEWE feed tank, WL-133, for processing in the WL-161 PEWE, as the Type I waste processing permits. Type 1 wastes will continue to be collected in WL-133 for processing in the WL-129 PEWE. The WL-132 solids removal tank will continue to be used to remove the solids from either Type of waste as they are transferred into WL-133. PEWE bottoms concentrate from Type 1 waste processing will be drained into PEWE bottoms tank, WL-101, where it will be held until transferred to WM-183, and Type 2 waste processing will be drained into PEWE bottoms tank, WL-111, where it will be held until transferred to WM-182. The wastes in WM-182 and WM-183 can be transferred to the NWCF for processing or to any other tank farm tank for blending using the existing tank farm piping. Any new waste treatment facilities will also be connected to this same piping. This waste segregation will not effect the consent order dates for having the tank farm tanks emptied. The only changes to the PEWE operation will be receiving the Type 2 PEWE feed solutions into the WM-100, WM-101, and WM-102 tanks and the operation of the new WL-111 tank along with the WL-101 tank. The overhead vapor from both WL-129 and WL-161 PEWEs will continue to be collected in the condensate collection system and processed by the Liquid Effluent Treatment and Disposal (LET\&D) facility. The PEWE waste transfer and evaporator operations will be accomplished following the existing operating procedures and safety documents.

\section{Detailed Plan}

\section{PEWE Feed Collection}

The Type 2 wastes (ref. 2) from CPP-666 (FSA \& FDP), CPP-601 (CFD, PEW and lab drains), CPP-603 (Wet \& Dry), CPP-641 (Pilot Plants and future lab drains), RCRA Wells (via CPP601), non-ICPP INEEL Wastes, and the NWCF utility tunnel water (via CPP-601) will be held at the waste generating facilities or transferred to WM-100, WM-101, and WM-102. These wastes will be held until the PEWE/LET\&D can be used to process the accumulated waste. WM-100, WM-101, and WM-102 can hold up to 52,000 gallons.

The Type 1 wastes from NWCF, and the NWCF decon room (includes both filter leach and decon wastes) will be transferred to WL-133 and processed by the PEWE until sufficient Type 2 wastes are available for processing. When Type 2 wastes are being processed by PEWE the Type 1 wastes will have to be held in the waste generating facility until the Type 2 waste run is complete (normally 3 to 6 days). 
Astachment

November 18,1997

FSW-17-97

Page 3 of 6

The remaining Type 2 wastes from CPP-633 (WCF sumps), Tank Farm sumps, CPP-604 sumps, LET\&D and the Miscellaneous Balance of Plant sources will be held in the waste generating facilities and transferred to WL-133 when the Type 2 waste is being processed or transferred to WL-133 and processed with the Type 1 wastes if they cannot be held until the Type 2 waste is being processed. There are no interim storage tanks available for these facilities. Since Type 1 waste is the more restrictive Type any mixing of waste Types will be considered Type 1 waste.

The WL-132 solids removal tank will continue to be used to remove the solids from either Type $\cdots$ of waste as they are transferred into WL-133.

\section{PEWE Operation}

The WL-133 feed collection tank will be the feed tank to the PEWE for both Type 1 and Type 2 wastes, as it is used now. Transfers of Type 1 waste will be made to WL-133 and fed to the WL129 evaporator for processing. When there is a sufficient volume of Type 2 waste, WL-133 will be emptied to the $10 \%$ heel of Type 1 waste and the WL-129 evaporator will be shut down. The accumulated Type 2 waste in the generating facilities and WM-100, WM-101, and WM-102 will be transferred to WL-133 and fed to the WL-161 evaporator. When a sufficient volume of Type 2 waste has been processed to allow routine operations in the generating facilities or enough Type 1 waste has been generated, that the generating facilities can no longer store it, then WL133 will be emptied to the $10 \%$ heel of Type 2 waste and the WL-161 will be shut down. WL133 will be switched back to collecting Type 1 waste and WM-100, WM-101, WM-102 will continue to collect the Type 2 waste and the cycle will be repeated.

The WL-129 evaporator will be drained to the WL-101 Bottoms Collection Tank (Type 1) and the WL-161 evaporator will be drained to the new WL-111 Bottoms Collection Tank (Type 2). Either evaporator could be used to process either Type of waste and drained to either bottoms collection tank if the need arises, but for easier waste tracking, procedure writing and operating plans the system will normally be used, as outlined above.

The overhead vapor from both WL-129 and WL-161 PEWEs will continue to be condensed and collected in the condensate collection system. The collected condensate will then be processed by the Liquid Effluent Treatment and Disposal (LET\&D) facility or recycled using the existing procedures and limits.

If during routine processing of either Type of waste, the evaporator must be shutdown before the bottoms are as concentrated as desired (e.g. lack of feed or condensate tanks full), the bottoms can be drained back to the WL-133 feed tank and reprocessed. If the condensate created during any operation does not meet the standards for processing through LET\&D it can also be drained back to WL-133 and reprocessed. Additionally, if the need should arise, the bottoms collection tanks WL-101 and WL-111 can be transferred to the feed collection tank WL-133 and reprocessed. 
If during either Type of waste processing an "emergency" arises and the other Type of waste must be processed the waste will be handled as follows:

Type 1 to Type 2 switch - WL-129 will be shutdown and drained to WL-101 or WL-133. The remaining Type 1 waste in WL-133 will be transferred to WL-102 for temporary storage and then transferred back to WL-133 when Type 1 waste is again being collected and processed. After the WL-133 liquid level has been lowered to $10 \%$, the Type 2 waste can be transferred into WL-133 and processed per the normal procedures.

Type 2 to Type 1 switch - WL-161 will be shut down and drained to WL-111. The Type 1 waste will be transferred into WL-133, which will then be fed to the WL-129 evaporator. Any Type 2 waste remaining in WL-133 will become part of the Type 1 waste since it is the more restrictive waste Type.

\section{Concentrated Bottoms Collection and Transfer}

The Type 1 bottoms from the operation of WL-129 will be drained to WL-101 and held there until transferred to tank WM-183. WM-183 has been designated as the Type 1 bottoms collection tank until another tank is emptied by NWCF and can be used for the Type 1 bottoms. The present plan is to use WM-183 as the first tank farm tank to be closed.

The Type 2 bottoms from the operation of WL-161 will be drained to WL-111 and held there until transferred to tank WM-182. WM-182 has been designated as the Type 2 bottoms collection tank. The present plan is to use the accumulated solution in WM-182 as the first feed for the new grout facility, if that is the approved method for waste disposal. Once WM-182 has been emptied by the grout plant or by the HLLWE or NWCF operation there are no plans to refill it and it could then also be closed. The Type 2 waste stored in WM-182 could be transferred into another tank farm tank (or new tanks supplied by the new facilities) in order to close this tank earlier for various reasons. Those reasons may include: 1 . Closure of WM-182 at the same time WM-183 is closed, since these two tanks are interconnected, prior to construction of the new planned waste treatment facilities. 2. If the consent order date of March 2009, for cease use of the pillar and panel vaulted tanks, is in danger of being missed and the new facilities are not operational but other tanks are available.

WL-101 can hold up to 16,000 gallons before a transfer is made to WM-183 with the normal transfer volume in the 6,000 to 12,000 gallons range. Normally 4-8 transfers are made each year. WL-161 can also be drained to WL-101 if it is used to process Type 1 waste. WL-111 can hold up to 1,200 gallons before a transfer is made to WM-182. Normally 10-20 transfers will be made each year. WL-129 can also be drained to WL-111 if it is used to process Type 2 waste. If an upset condition or other operating need occurs, the waste solutions in either WL-101 or WL-111 can be transferred at any time to any of the tank farm tanks, NWCF, HLLWE, or WL-133. 
Additionally either bottoms tank could be used for either Type of waste solution from either evaporator if the need arises. It would be best if the bottoms tank was emptied before the waste Type is switched but emptying would not be required in an "emergency" situation.

\section{References}

1. Letter J. L. Tripp, JLT-08-96 and F. S. Ward, FSW-16-96 to J. E. Hovinga and T. A. Mathews, FY-96 Tank Farm Waste Generation and FY-97 Incentive Baseline, dated November 6, 1996.

2. Report INEEL/EXT-97-00988, J. L. Tripp, Idaho Chemical Processing Plant Waste Minimization Plan, published August 1997.

3. Letter J. L. Tripp, JLT-06-97 and F. S. Ward, FSW-07-97 to J. E. Hovinga and T. A. Mathews, Status of the FY-97 Waste Generation Compared to Draft FY-97 Incentive Baseline, dated April 28, 1997.

4. Report DOE/ID-10544, Tom Wichmann, Nicole Brooks, Mike Heiser, Regulatory Analysis and Proposed Path Forward for the Idaho National Engineering Laboratory High-level Waste Program, Revision 1, dated October 1996. 


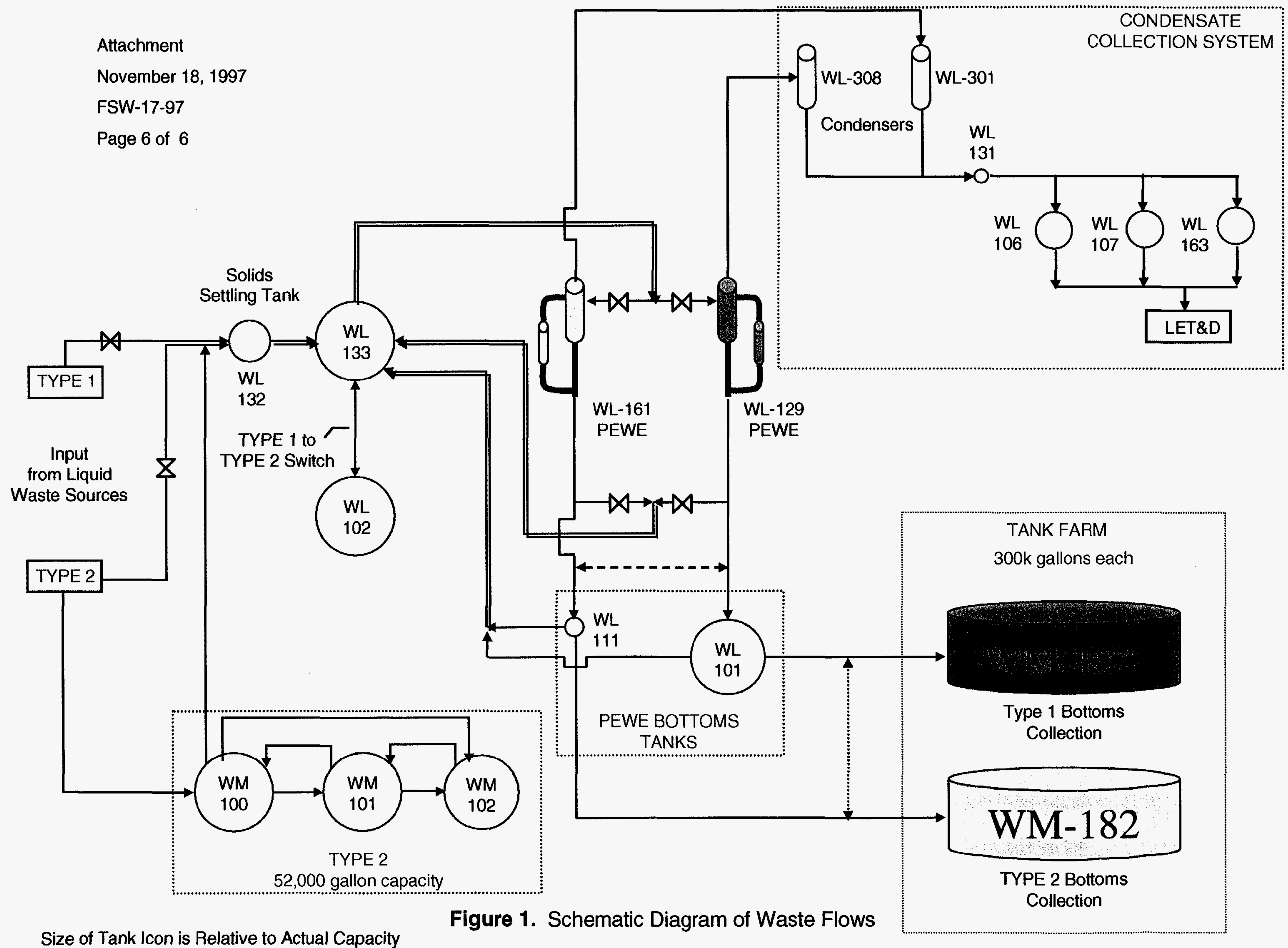

